\title{
Age and Origin of Base- and Precious-Metal Veins of the Coeur D'Alene Mining District, Idaho
}

R. J. Fleck, R. E. Criss, G. F. Eaton, R. W. Cleland, C. S. Wavra, W. D. Bond

November 7, 2000 


\section{DISCLAIMER}

This document was prepared as an account of work sponsored by an agency of the United States Government. Neither the United States Government nor the University of California nor any of their employees, makes any warranty, express or implied, or assumes any legal liability or responsibility for the accuracy, completeness, or usefulness of any information, apparatus, product, or process disclosed, or represents that its use would not infringe privately owned rights. Reference herein to any specific commercial product, process, or service by trade name, trademark, manufacturer, or otherwise, does not necessarily constitute or imply its endorsement, recommendation, or favoring by the United States Government or the University of California. The views and opinions of authors expressed herein do not necessarily state or reflect those of the United States Government or the University of California, and shall not be used for advertising or product endorsement purposes.

This work was performed under the auspices of the U. S. Department of Energy by the University of California, Lawrence Livermore National Laboratory under Contract No. W-7405-Eng-48.

This report has been reproduced directly from the best available copy.

Available electronically at http://www.doc.gov/bridge

Available for a processing fee to U.S. Department of Energy

And its contractors in paper from

U.S. Department of Energy

Office of Scientific and Technical Information

$$
\text { P.O. Box } 62
$$

Oak Ridge, TN 37831-0062

Telephone: (865) 576-8401

Facsimile: (865) 576-5728

E-mail: reports@adonis.osti.gov

Available for the sale to the public from

U.S. Department of Commerce

National Technical Information Service

5285 Port Royal Road

Springfield, VA 22161

Telephone: (800) 553-6847

Facsimile: (703) 605-6900

E-mail: orders@ntis.fedworld.gov

Online ordering: http://www.ntis.gov/ordering.htm

\section{OR}

Lawrence Livermore National Laboratory

Technical Information Department's Digital Library

http://www.llnl.gov/tid/Library.html 
coeur.doc $11 / 7 / 00$

AGE AND ORIGIN OF BASE- AND PRECIOUS-METAL VEINS OF THE COEUR D'ALENE MINING DISTRICT, IDAHO

\section{Robert J. Fleck}

U.S. Geological Survey MS 937, 345 Middlefield Rd., Menlo Park, CA 94025

Robert E. Criss

Department of Earth and Planetary Sciences, Washington University, St. Louis, MO 63130

Gail F. Eaton

Lawrence Livermore National Laboratory, Livermore, CA 94550

Rodney W. Cleland, Craig S. Wavra ${ }^{\dagger}$, and William D. Bond

Sunshine Precious Metals Company, P.O. Box 1080, Kellogg, ID 83837

\footnotetext{
$\dagger$ Deceased
} 


\section{ABSTRACT}

Ore-bearing quartz-carbonate veins of the Coeur d'Alene mining district yield ${ }^{87} \mathrm{Sr} /{ }^{86} \mathrm{Sr}$ ratios of 0.74 to $>1.60$ for low- $\mathrm{Rb} / \mathrm{Sr}$, carbonate gangue minerals, similar to current ranges measured in Middle Proterozoic, high-Rb/Sr rocks of the Belt Supergroup. Stable-isotope and fluid-inclusion studies establish a genetic relationship between vein formation and metamorphic-hydrothermal systems of the region. These extraordinary ${ }^{87} \mathrm{Sr} /{ }^{86} \mathrm{Sr}$ ratios require accumulation of radiogenic ${ }^{87} \mathrm{Sr}$ in a high $\mathrm{Rb} / \mathrm{Sr}$ system over an extended period prior to incorporation of $\mathrm{Sr}$ into the veins by hydrothermal processes. Evaluation of the age and composition of potential sources of highly radiogenic Sr indicates that the ore-bearing veins of the Coeur d'Alene district formed within the last 200 Ma from components scavenged from sedimentary and metasedimentary rocks of the Belt Supergroup, the primary host-rocks of the district. These results are consistent with a Cretaceous or Early Tertiary age for these veins. $\mathrm{Pb}-\mathrm{Zn}$ deposits that yield $\mathrm{Pb}$ isotope, $\mathrm{K}$ - $\mathrm{Ar}$, and Ar-Ar results indicative of a Proterozoic age probably formed during deposition or diagenesis of the Belt Supergroup at 1350-1500 Ma, possibly as Sullivan-type syngenetic deposits.

$\mathrm{K}$-Ar and $\mathrm{Rb}-\mathrm{Sr}$ apparent ages and $\delta^{18} \mathrm{O}$ values of Belt Supergroup rocks decrease southward from the Coeur d'Alene district toward the Idaho batholith, normal to the trends of metamorphic isograds, fold axes, foliation, and the major reverse faults of the district. Isoclinal folding, thrust faulting, high-temperature metamorphism, granitic plutonism, and regional-scale metamorphic-hydrothermal activity is documented in the region between $140 \mathrm{Ma}$ and $45 \mathrm{Ma}$, but no similar combination of events is recognized for Late Proterozoic time. Combined with $\mathrm{Sr}$ results from the veins, the evidence strongly favors formation of the ore-bearing carbonate veins of the district by fluids related to a complex metamorphic-hydrothermal system during Cretaceous and/or early Tertiary time. Proterozoic $\mathrm{Pb}-\mathrm{Zn}$ deposits were probably deformed, remobilized along younger structures, and incorporated into the younger hydrothermal deposits during this event. 


\section{INTRODUCTION}

The present study was initiated to evaluate the age and source of mineralization in the Coeur d'Alene mining district, which remain controversial despite extensive mapping and structural, geophysical, geochemical, and isotopic studies that began over a century ago and continue today (Criss and Fleck, 1990; Criss and Eaton, 1998; Leach et al., 1998a,b). We present results of $\mathrm{Sr}$ isotopic studies of carbonate gangue from veins throughout the Coeur d'Alene district and discuss the constraints they place on the age of mineralization. Previous studies of the district provide the context into which these results must be placed.

Although the Proterozoic age of the Belt Supergroup was understood previously, Calkins subdivided the strata into recognizable mapping units in the Coeur d'Alene district (Ransome and Calkins, 1908). Obradovich and Peterman (1968) reported Rb-Sr and K-Ar ages of about $1100 \mathrm{Ma}$ for equivalents of the Wallace and St. Regis Formations of the Belt Supergroup, but argued for an age of about 1325 Ma for equivalents of the Revett, Burke, and Prichard Formations. Recent U-Pb studies on zircon by Anderson and Davis (1995) and Aleinikoff et al. (1996) indicate that the majority of the Belt Supergroup in southeast British Columbia and western Montana is older than $1440 \mathrm{Ma}$, increasing the estimated age of Belt sedimentation. Units of the Belt Supergroup are host rocks for the vein systems of the Coeur d'Alene district and these ages must represent maximum ages for the mineralization.

After extensive mapping of the district and adjacent areas, Ransome and Calkins (1908) concluded that fracture systems related to emplacement of the Idaho batholith controlled the major ore-bearing veins. Additionally, they concluded "beyond reasonable doubt" that the most probable sources of the hot fluids responsible for ore deposition were underlying magmas related to the Idaho batholith, to which Lindgren (1904) assigned a late Mesozoic (post-Triassic) age (Ransome and Calkins, 1908, p. 137). Hershey $(1912,1916)$ provided detailed field studies linking ore deposition to the emplacement of monzonite stocks and felsic dikes, arguing persuasively that the intrusions were the direct cause of circulation of the fluids that dissolved 
the metals from the host strata (Hershey, 1916, p. 14). Hershey $(1916,1917)$ also described the complex relationship of the monzonite intrusive rocks to the ore bodies, detailing evidence of interrelated intrusion, metamorphism, and vein emplacement during which monzonite masses both truncated and were invaded by mineralized veins. Umpleby and Jones (1923) extended these studies, concluding that the ore deposits of the Coeur d'Alene district were formed in the late Mesozoic as hot, ascending solutions deposited metals derived from either underlying magmas or disseminated ores in the sedimentary wall rocks. They favored a magmatic source for these metals (Umpleby and Jones, 1923, p. 149). These early studies related the ore-bearing veins to Mesozoic igneous activity but debated sedimentary versus igneous sources for the metals. McDowell (1971) obtained K-Ar ages on hornblende from monzonite of the Gem stocks of 131-137 Ma (corrected to currently accepted decay constants), establishing a maximum age for at least some of the Coeur d'Alene veins. Schalck (1989) summarized age results for a northeast-trending group of plutons that includes the Gem stocks (Fig. 1), showing apparent ages ranging from about $100 \mathrm{Ma}$ for the Trout Creek pluton in the northeast to $137 \mathrm{Ma}$ at Gem. Age and isotopic studies by Fleck and Criss (1985) and Criss and Fleck (1987, 1990) established the Cretaceous and early Tertiary age of the northern (Bitterroot) lobe of the Idaho batholith and its related, regional-scale, metamorphic-hydrothermal system that includes the Coeur d'Alene district.

Kerr and Kulp (1952), Kerr and Robinson (1953), and Eckelmann and Kulp (1957) reported $\mathrm{U}-\mathrm{Pb}$ ages ranging from $1190-1035 \mathrm{Ma}$ for uraninite from pyrite-jasper veins in the Sunshine mine that predate base- and precious-metal veins. Long et al. (1960), Silverman et al. (1960), and Cannon et al. (1962) reported Pb-isotope data for galena from Coeur d'Alene veins that separated from parent uranium and thorium about $1400 \mathrm{Ma}$, concluding that these data established a Precambrian age of vein formation. Fryklund (1964) presented an alternative interpretation of the $\mathrm{Pb}$-isotopic results, pointing out that a Precambrian age interpretation for Coeur d'Alene veins requires a pivotal assumption that the time of uranium separation was also the time of incorporation of $\mathrm{Pb}$ into the veins. Zartman and Stacey (1971) provided additional 
$\mathrm{Pb}$-isotopic results for galenas and endorsed the arguments for Precambrian mineralization. Hobbs (1971) reported a new U-Pb age of $1250 \mathrm{Ma}$ on the uraninite veins, but expressed concern about the compatibility of this Middle Proterozoic U-Pb age with the timing of deformation of Belt strata in this area. From fluid inclusion and K-Ar studies, Leach et al. (1988) concluded that ore deposition occurred at $250^{\circ}$ to $350^{\circ} \mathrm{C}$ at about $850 \mathrm{Ma}$, although the measured ages range from $876 \mathrm{Ma}$ to $77 \mathrm{Ma}$. They considered apparent ages younger than about $850 \mathrm{Ma}$ to be disturbed by subsequent thermal events. Leach et al. (1998a) reported new Ar-Ar apparent ages from sericite (muscovite in their Table 2) that range from 65 to over 1017 Ma. They argued that veins of the Coeur d'Alene district formed in both Proterozoic and Cretaceous time. A crucial study by Zartman and Smith (1995) demonstrated that uranium-bearing jasper veins of the Sunshine mine, dated originally at $800-1250 \mathrm{Ma}$, contained Early Cretaceous (133 $\pm 6 \mathrm{Ma}$ ) zircons and brannerite. They concluded that these veins, which preceded the main-phase siderite-tetrahedrite veins, were emplaced in the Early Cretaceous, but incorporated variable amounts of Proterozoic common $\mathrm{Pb}$ and both detrital and volcanogenic(?) zircons.

Papers by Criss and Eaton (1998) and Leach et al. (1998b) define the present status of the controversy on the age of the Coeur d'Alene veins. The research on the age and origin of these veins over the last century has established a number of areas of agreement. Most investigators accept that $\mathrm{Pb}$ in the Coeur d'Alene veins separated from uranium in mid-Proterozoic time, probably about $1400 \pm 200 \mathrm{Ma}$. Where that $\mathrm{Pb}$ resided until the present is not an area of agreement, however (e.g. Fleck et al., 1991; Constantopoulos, 1994; Zartman and Smith, 1995; Leach et al, 1998a). Most current workers accept measurements of high ${ }^{87} \mathrm{Sr} /{ }^{86} \mathrm{Sr}$ in the carbonate gangue as evidence that those veins formed in Phanerozoic time. Although strong arguments can be made for this occurring in the late Mesozoic or early Tertiary (Criss and Fleck, 1990; Fleck et al., 1991; Eaton et al., 1995; Leach et al, 1998a), others have suggested that a preBelt source may have provided the highly radiogenic $\mathrm{Sr}$ to the veins in Proterozoic time (Rosenberg and Larson, 1996). Finally, there seems to be general acceptance that the primary vein materials were derived by metamorphic-hydrothermal processes from terranes whose 
protoliths were largely sedimentary (Leach et al., 1988; Criss and Fleck, 1990; Constantopoulos, 1994; Eaton et al, 1995; Leach et al, 1998a).

\section{GEOLOGIC SETTING}

The Coeur d'Alene mining district of northern Idaho and westernmost Montana (Fig. 1) lies within the Middle Proterozoic depositional basin of the Belt Supergroup, a thick sequence of marine, lacustrine, and terrestrial quartzite and argillite strata with several significant carbonaterich intervals (Harrison, 1972). The district represents a west-northwest-trending zone of baseand precious-metal mineralization within the Lewis and Clark line, a 50- to 100-km-wide, 200to 250-km-long zone of WNW-trending structures in northern Idaho and western Montana (Billingsley and Locke, 1939; Wallace, et al., 1960; Hobbs et al., 1965; Reynolds and Kleinkopf, 1977; Harrison et al., 1980; Price, 1981; White, 1998a, 2000; White and Applegate, 2000; White et al., 2000a). The mineralized area lies at the intersection of long-lived north-south-trending structures defined by Middle Proterozoic deposition as well as the more obvious north- to NNWtrending structures of the Cordilleran fold and thrust belt (Wallace, et al., 1960; Harrison et al., 1986; White, 2000). The Hope, Ninemile, St. Mary's, Osburn, and St. Joe faults represent significant vertical and horizontal displacements within the Lewis and Clark zone, but an abrupt transition from a northerly structural trend to a penetrative WNW tectonic fabric occurs near the Osburn fault (Wallace, et al., 1960; Hobbs et al., 1965; Harrison et al., 1980; Bennett and Venkatakrishnan, 1982; White, 1998a; White and Applegate, 2000). The Osburn fault, which bisects the Coeur d'Alene mining district along the same WNW trend, has about $26 \mathrm{~km}$ of rightlateral, strike-slip displacement (Hershey, 1916; Umpelby and Jones, 1923; Umpelby, 1924; Hobbs et al., 1965; Gott and Cathrall, 1980; Bennett and Venkatakrishnan, 1982). Strike-slip movement on the Osburn fault postdates much of the folding in the Coeur d'Alene district (Hobbs et al. 1965; White, 1998a), although we suggest that structural trends near the fault could have been modified by synchronous development of compressional features and strike-slip faulting, which is well documented along other major strike-slip structures such as the San 
Andreas fault (Mount and Suppe, 1987; Miller, 1998). White (1998a) provides evidence that north-trending folds that define the primary structural trend north of the Coeur d'Alene district actually persist into the area near the Osburn fault where west-northwest-trending folds are predominant, although their effects are subtle. Both sets of folds appear to predate emplacement of the ore-bearing veins of the district, however. Deformation along the Lewis and Clark zone probably began in Precambrian time (White, 1994; 1998a; 2000). Displacement of 52 \pm 3 Ma-old, hornblende-bearing, granitic dikes by the Hope fault, one of the northernmost faults of the zone, however, indicates Eocene or younger movement (Fillipone et al., 1992). Numerous dikes in the Coeur d'Alene district occupy fractures subparallel to the Osburn fault. A K-Ar age of $52.0 \pm 1.5$ Ma on biotite and similar but complex ages on hornblende are reported by McDowell (1971) for a lamprophyric dike in the Star mine, suggesting that other fractures within the Lewis and Clark line such as the Osburn fault also may have been active at this time.

Although exceptions occur, most economically important $\mathrm{Pb}-\mathrm{Zn}-\mathrm{Ag}$ veins of the district occur along northwest striking, south-southwest-dipping fractures, which are subparallel to highangle faults, shear zones, fold axes, foliation, and axial-plane cleavage that define the dominant structural fabric on both sides of the Osburn fault (Fryklund, 1964). All of the vein systems predate movement along the Osburn fault and may be strongly sheared by post-emplacement movement along the fractures. Wavra et al. (1994) conclude that mineralization in the Sunshine mine occurred during a high-angle, reverse-slip, tectonic-metamorphic event, with major oreshoots plunging steeply to the southwest. White (1998a) summarized observations supporting this interpretation. Vein systems in the district exhibit significant variability in mineralogy, but galena, tetrahedrite, and sphalerite are the most important ore minerals, whereas the primary gangue minerals are siderite, ankerite, and quartz in highly variable proportions (Fryklund, 1964). 


\section{ANALYTICAL METHODS}

\section{Rubidium-Strontium Methods}

Whole-rock samples used in this study were crushed and split from 1 to $3 \mathrm{~kg}$ of rock, powdered to less than 200 mesh, and homogenized prior to taking aliquants for analysis.

Carbonate mineral separates were made with heavy liquids, magnetic separation, and hand picking, with grain sizes ranging from 0.1 to $1.0 \mathrm{~mm}$. Whole-rock samples were treated by standard silicate-digestion $\left(\mathrm{HF}+\mathrm{HNO}_{3} \pm \mathrm{HClO}_{4}\right)$ techniques, whereas carbonates were digested in $\mathrm{HCl}$. Following digestion of the samples, $\mathrm{Rb}$ and $\mathrm{Sr}$ were separated by ion-exchange techniques and concentrations were determined by isotope-dilution mass spectrometry. Two different techniques were utilized for carbonate samples. Early in the study $\mathrm{HCl}$ digestion was followed by precipitation of $\mathrm{Fe}(\mathrm{OH})_{2}$ by addition of high-purity $\mathrm{NH}_{4} \mathrm{OH}$, filtration, and centrifugation. Siderites with $85-95 \% \mathrm{FeCO}_{3}$ required multiple cycles, during which co-precipitation of $\mathrm{Sr}$ resulted in reduced yields for mass spectrometry. Whereas the prior addition of ${ }^{84} \mathrm{Sr}$ tracer makes actual Sr yield of little consequence in most isotope dilution analyses, the precipitation procedure for removing $\mathrm{Fe}(\mathrm{OH})_{2}$ is time consuming and probably results in co-precipitation of Sr. After the initial results made the value of the isotopic work clear, a second procedure was instituted involving no Fe precipitation. Samples were dissolved in $\mathrm{HCl}$, dried, and redissolved in $\mathrm{HNO}_{3}$. The solution was then passed through an Eichrom SrSpec column in $3 \mathrm{M} \mathrm{HNO}_{3} . \mathrm{Sr}$ was stripped with high-purity $\mathrm{H}_{2} \mathrm{O}$ and analyzed directly on the mass spectrometer. Analyses are rapid and $\mathrm{Sr}$ yield is better than $95 \%$. Analytical uncertainties in $\mathrm{Rb}$ and $\mathrm{Sr}$ concentrations are commonly 0.3 to 1.0 percent for concentrations above $25 \mathrm{ppm}$, but the coarse-grained siderites with 0.2 to $0.35 \mathrm{ppm} \mathrm{Rb}$ and 3 to $6 \mathrm{ppm} \mathrm{Sr}$ had variations of 3 to 5 percent, related in part to inhomogeneities in splitting. Isotopic measurements were made on a Finnigan MAT261 mass spectrometer with multiple collection. Analyses of National Bureau of Standards SRM 987 strontium carbonate $(n=9)$ during processing of these samples averaged $0.710246 \pm 0.000011$ 
(95\% confidence). Constants used for $\mathrm{Rb}-\mathrm{Sr}$ computations are: $\lambda_{\mathrm{Rb}}=1.42 \times 10^{-11} \mathrm{yr}^{-1},{ }^{86} \mathrm{Sr} /{ }^{88} \mathrm{Sr}=$ 0.1194 , and ${ }^{85} \mathrm{Rb} / 87 \mathrm{Rb}=2.59265$.

\section{Stable Isotope Techniques}

Siderite samples were reacted with $100 \%$ orthophosphoric acid $\left(\mathrm{H}_{3} \mathrm{PO}_{4}\right)$ at $50^{\circ} \mathrm{C}$ to release $\mathrm{CO}_{2}$ gas (Walters et al., 1972; Carothers et al., 1988). Detailed descriptions and a tabulation of stable isotope analyses are provided by Eaton (1993) and Eaton et al. (1995). Silicate rock samples were reacted with chlorine trifluoride $\left(\mathrm{ClF}_{3}\right)$ to release oxygen gas, which was then converted to $\mathrm{CO}_{2}$ gas with a heated graphite rod (Clayton and Mayeda, 1963; Borthwick and Harmon, 1982). Samples were analyzed on a MAT 251 gas-source mass spectrometer with automated sample inlet system by standard techniques. The $\delta^{18} \mathrm{O}$ values are reported relative to SMOW, whereas $\delta^{13} \mathrm{C}$ values are relative to PDB.

\section{RESULTS}

$\mathrm{Rb}, \mathrm{Sr},{ }^{87} \mathrm{Sr} /{ }^{86} \mathrm{Sr}, \delta^{18} \mathrm{O}$ and $\delta^{13} \mathrm{C}$ were measured on siderite, ankerite, and calcite mineral separates from base-and precious-metal-bearing veins of the Coeur d'Alene mining district (Table 1). Most of the analyses from the Sunshine mine were performed on the same mineral separates studied by Eaton (1993) and Eaton et al. (1995). Additional carbonate samples were collected at underground sites in the Coeur, Caladay, Galena, Gold Hunter, and Lucky Friday mines, and from mine dumps at the Matchless, Highland Surprise, Carbonate Hill, and Bullion mines (Fig. 1). These locations range approximately $45 \mathrm{~km}$ along the length of the district, from Pine Creek on the west (the Matchless mine) to the Bullion mine one mile west of the Montana State line. Two of the mines, the Lucky Friday and Gold Hunter, are north of the major WNWtrending Osburn fault, whereas the remaining eight are on the south side. Sampling within the Sunshine mine was the most extensive, covering nine major veins, depths from 500 to 5600 feet, and including two detailed sample traverses across the width of individual veins.

As may be noted in Table 1, Rb concentrations in the carbonate gangue from all the mines are extremely low, ranging from $0.03 \mathrm{ppm}$ to less than $2 \mathrm{ppm}$. Sr concentrations in 
siderite are also very low, but values in calcite or ankerite may be greater than $1500 \mathrm{ppm}$, as in 918-17F calcite from the Highland Surprise mine. Measured ${ }^{87} \mathrm{Sr} /{ }^{86} \mathrm{Sr}$ ratios in the carbonate minerals are extremely high, averaging about 0.9 , but with values greater than 1.6 (Table 1 ). All analyses lie above a 1600-Ma reference isochron on an $\mathrm{Rb}$-Sr correlation diagram (Fig. 2), emphasizing the enormous enrichment of ${ }^{87} \mathrm{Sr}$ and the absence of any age-related correlation between ${ }^{87} \mathrm{Rb} /{ }^{86} \mathrm{Sr}$ and ${ }^{87} \mathrm{Sr} /{ }^{86} \mathrm{Sr}$ in the carbonate minerals. Plotting ${ }^{87} \mathrm{Sr} /{ }^{86} \mathrm{Sr}$ against $1 / \mathrm{Sr}$, however, reveals an erratic but positive co-variation in the vein carbonates (Fig. 3). As might be expected from the wide variations measured within a given vein (Table 1), the vein-average data are dispersed, but reveal a clear trend (correlation coefficient $\cong 0.35$ for $1 / \mathrm{Sr}$ ). Such a correlation would be expected from random mixtures of a high-Sr, low ${ }^{87} \mathrm{Sr} / 86 \mathrm{Sr}$ component with a second, containing low $\mathrm{Sr}$ and high but variable ${ }^{87} \mathrm{Sr} /{ }^{86} \mathrm{Sr}$. Variations of ${ }^{87} \mathrm{Sr} /{ }^{86} \mathrm{Sr}$ between samples are large even within individual veins (Table 2), but mean values of the vein systems reflect their geographic position. South of the Osburn fault, mines in the central or "Silver Belt" portion of the Coeur d'Alene district (the Sunshine, Coeur, Galena, and Caladay mines; Fig. 1) have significantly higher mean ${ }^{87} \mathrm{Sr} /{ }^{86} \mathrm{Sr}$ than those to the east or to the west. This central zone coincides roughly with the mineralized area where carbonate gangue is dominated by siderite, as noted by Fryklund (1964). Because Sr concentration increases with Ca concentration from siderite to ankerite to calcite (Tables 1,2), the Sr content of vein carbonate (Table 1) also confirms the mineralogical variation of gangue within the district. The $\mathrm{Sr}$ content is higher in veins of the eastern and western parts of the district, where Fryklund reports ankerite instead of siderite.

Oxygen and carbon isotopic analyses have been described in detail elsewhere (Criss and Fleck, 1990; Fleck et al., 1991; Eaton et al., 1992; 1993; 1995) and will be discussed only as they relate to the interpretation of $\mathrm{Sr}$ results. Data reported in Table 1 are similar to those of Yates (1987) for the Galena mine (Fig. 1), defining a positive linear correlation between $\delta^{13} \mathrm{C}$ and $\delta^{18} \mathrm{O}$ (Fig. 4). The trends are similar to those defined in other carbonate-hosted, base- and preciousmetal veins (Seal and Rye, 1992), as well as in metamorphic-hydrothermal systems (Nabelek et 
al., 1984), and are interpreted as primary hydrothermal variations established during ore deposition (Eaton et al., 1995).

Two of the sample suites in Table 1 represent sample traverses across siderite-tetrahedrite veins in the Sunshine mine at $10 \mathrm{~cm}$ intervals. The shorter crosses an uncomplicated part of the Copper vein (Fig. 5), whereas the longer traverse spans the width of a structurally complex part of the D-vein (Fig. 6). Stable isotope results for siderite from these traverses are crucial to interpretation of the timing of vein emplacement relative to regional metamorphism. Both vein traverses document significant variation in both $\mathrm{Sr}$ and stable isotope ratios. The quasisymmetrical decrease in the heavy isotope $\left({ }^{13} \mathrm{C}\right.$ and $\left.{ }^{18} \mathrm{O}\right)$ from the vein margins to the center strongly supports a progressive growth of the veins inward from the walls of the fracture as fluid temperatures increased (Fig. 5). Based on these results, Eaton et al. (1995) argue that decarbonation of the fluids, caused by carbonate deposition, $\mathrm{CO}_{2}$ loss, or both, may also have been a factor because temperature alone would be inadequate to reduce $\delta^{13} \mathrm{C}$ to the extent observed. Whole-rock $\delta^{18} \mathrm{O}$ values in the wall rock adjacent to the veins also increased (Fig. 6).

Large variations also occur in $1 / \mathrm{Sr}$ and ${ }^{87} \mathrm{Sr} / 86 \mathrm{Sr}$ across the veins. These two parameters are strongly correlated in Copper vein siderites (Fig.5), supporting arguments for a mixing relationship between components with high $\mathrm{Sr}$, low ${ }^{87} \mathrm{Sr} /{ }^{86} \mathrm{Sr}$ and low $\mathrm{Sr}$, high ${ }^{87} \mathrm{Sr} /{ }^{86} \mathrm{Sr}$. Because variations in ${ }^{87} \mathrm{Sr} / 86 \mathrm{Sr}$ are unrelated to isotopic fractionation, the correlation indicates a sourcerelated control of $\mathrm{Sr}$ variation. Argillite in the Belt Supergroup is commonly higher in $\mathrm{Rb} / \mathrm{Sr}$ and lower in $\mathrm{Sr}$ than quartzite- or limestone-dominated sequences. ${ }^{87} \mathrm{Sr} /{ }^{86} \mathrm{Sr}$ from old, high- $\mathrm{Rb} / \mathrm{Sr}$ argillite will be much higher than Belt limestone or dolomite, which has minimal $\mathrm{Rb}$ and ${ }^{87} \mathrm{Sr} /{ }^{86} \mathrm{Sr}$ will be changed little from seawater values by ${ }^{87} \mathrm{Rb}$ decay (e.g., Obradovich and Peterman, 1968). Quartzite of the Belt Supergroup commonly has lower $\mathrm{Rb} / \mathrm{Sr}$ ratios than Belt argillite, and also may contain considerable carbonate. As a result, metamorphic fluids in equilibrium with Belt carbonate or quartzite would have lower ${ }^{87} \mathrm{Sr} /{ }^{86} \mathrm{Sr}$ than those from argillite of a similar age. Although less apparent in Copper vein analyses (Fig. 5), analyses of the D-vein record a clear but imperfect anti-correlation between Sr and stable isotopes variations (Fig. 6). 
Regardless whether these variations are source-controlled or fractionation-related, the large, systematic isotopic variations documented across Coeur d'Alene veins are related to primary fluctuations in the ore-forming fluids that were established during vein deposition and argue against post-depositional metamorphic homogenization.

\section{SOURCE OF STRONTIUM IN COEUR D'ALENE CARBONATE VEINS}

As illustrated in an isochron diagram (Fig. 2), the extremely radiogenic ${ }^{87} \mathrm{Sr} / 86 \mathrm{Sr}$ in Coeur d'Alene carbonate gangue minerals with very low ${ }^{87} \mathrm{Rb} /{ }^{86} \mathrm{Sr}$ could not have evolved in situ. Decay of present amounts of $\mathrm{Rb}$ in these minerals would account for only trivial amounts of the radiogenic ${ }^{87} \mathrm{Sr}$. The $\mathrm{Sr}$ in carbonate vein minerals is so highly radiogenic that if we assume an initial ${ }^{87} \mathrm{Sr} /{ }^{86} \mathrm{Sr}\left(\mathrm{Sr}_{\mathrm{i}}\right)$ equal to modern seawater (0.70915), the youngest $\mathrm{Rb}-\mathrm{Sr}$ apparent age of all these carbonate minerals $(7.44 \mathrm{Ga}$ ) would exceed the age of Earth. The unsupported radiogenic ${ }^{87} \mathrm{Sr}$ and high ${ }^{87} \mathrm{Sr} /{ }^{66} \mathrm{Sr}$ of the veins are incontrovertible evidence that the $\mathrm{Sr}$ evolved in a system with substantially higher $\mathrm{Rb} / \mathrm{Sr}$ over a significant period prior to incorporation in the vein. An ancient, high $\mathrm{Rb} / \mathrm{Sr}$ source must have been available at the time of vein formation or the highly radiogenic ${ }^{87} \mathrm{Sr} /{ }^{66} \mathrm{Sr}$ must have been introduced long after the veins were formed. Clearly, neither the most profoundly enriched mantle nor ancient lower crust is a potential source of the radiogenic Sr. The most obvious source of highly radiogenic ${ }^{87} \mathrm{Sr} /{ }^{86} \mathrm{Sr}$ is the variably metamorphosed, high-Rb/Sr sedimentary rocks of the Belt Supergroup (Hóbbs et al., 1965; Harrison, 1972; Gott and Cathrall, 1980; Hietanen, 1962; 1967; 1984; Criss and Fleck, 1987; 1990). Not coincidentally, the Belt rocks have long been viewed as the source of the ore metals (e.g. Hershey, 1912; 1916) and, more recently, the source of high $\delta^{18} \mathrm{O}$ in Coeur d'Alene veins (Criss and Fleck, 1990; Constantopoulos and Larson, 1991). An alternative explanation for the high ${ }^{87} \mathrm{Sr} /{ }^{86} \mathrm{Sr}$ might be to derive it from a high- $\mathrm{Rb} / \mathrm{Sr}$, pre-Belt basement that is not exposed in the district. Growth of the high ${ }^{87} \mathrm{Sr} /{ }^{86} \mathrm{Sr}$ could have occurred in Archean time, permitting a Proterozoic age for the veins. A different explanation that must be considered is that the elevated ${ }^{87} \mathrm{Sr} /{ }^{86} \mathrm{Sr}$ was introduced metasomatically into veins of Precambrian age during 
Mesozoic or early Tertiary metamorphism. Each of these explanations for the high ${ }^{87} \mathrm{Sr} /{ }^{86} \mathrm{Sr}$ observed in Coeur d'Alene ore veins affects the age assigned to that mineralization, making this evaluation critical to attaching age significance to these results.

\section{Belt Supergroup}

Evidence pointing to the Belt rocks as the probable source of $\mathrm{Sr}$ in Coeur d'Alene ore veins is compelling. As discussed, $\mathrm{Sr}$ isotopic compositions of the carbonate gangue preclude any possibility of significant in situ growth from decay of ${ }^{87} \mathrm{Rb}$. In addition to their mineralogy, the dominantly-carbonate ore veins exhibit abundant evidence of fluid (hydrothermal) origin, as discussed by numerous workers (Lindgren, 1904; Hobbs et al., 1965; Leach et al., 1988; Criss and Fleck, 1990; Constantopoulos and Larson, 1991; Eaton, 1995). Highly radiogenic Sr must have been incorporated into the carbonate veins without supporting $\mathrm{Rb}$, but the time of incorporation must be determined to constrain the age of the veins. If the isotopic character of the veins can be shown to be primary, formed during initial deposition from metamorphic hydrothermal fluids, Sr with highly radiogenic ${ }^{87} \mathrm{Sr} /{ }^{86} \mathrm{Sr}$ must have been incorporated from an old, high $\mathrm{Rb} / \mathrm{Sr}$ source and deposited with the ores from the vein-forming liquids. The veins must be younger than that source by the amount of time required for its very large ${ }^{87} \mathrm{Sr} /{ }^{86} \mathrm{Sr}$ to be produced by decay of ${ }^{87} \mathrm{Rb}$. If the highly radiogenic $\mathrm{Sr}$ was leached from Belt strata, the time required for growth of ${ }^{87} \mathrm{Sr}$ in those rocks can be estimated from Table 3, using the median ${ }^{87} \mathrm{Rb} /{ }^{86} \mathrm{Sr}$ and ${ }^{87} \mathrm{Sr} /{ }^{86} \mathrm{Sr}$ of Belt Supergroup rocks and their initial ${ }^{87} \mathrm{Sr} /{ }^{86} \mathrm{Sr}$. Based on these results, Belt wall rocks would have required at least 1000 m.y. to reach the median ${ }^{87} \mathrm{Sr} /{ }^{86} \mathrm{Sr}$ (0.906) of Coeur d'Alene veins. Because ${ }^{87} \mathrm{Sr} /{ }^{86} \mathrm{Sr}$ ratios as high as 1.6 are measured in the veins (Table 1 ), only Belt strata with the highest $\mathrm{Rb} / \mathrm{Sr}$ could have been a source for this $\mathrm{Sr}$ (Fig. 7). Even with the age of the Belt Supergroup in the Coeur d'Alene district as old as $1440 \mathrm{Ma}$ (Aleinikoff et al., 1996), the ${ }^{87} \mathrm{Sr} /{ }^{86} \mathrm{Sr}$ in the strata would not have been sufficient to be a source for the veins until Mesozoic time. These relationships, illustrated in Figure 8 at $850 \mathrm{Ma}$, show 
that in Late Proterozoic time ${ }^{87} \mathrm{Sr} /{ }^{86} \mathrm{Sr}$ values of Belt strata would not have been high enough to produce veins with ${ }^{87} \mathrm{Sr} /{ }^{86} \mathrm{Sr}$ over 1.0. Formation of these veins in Proterozoic time is precluded.

The genetic model of deriving highly radiogenic Sr from rocks of the Belt Supergroup involves depositing the carbonate-rich ore veins of the Coeur d'Alene district from Cretaceous or early Tertiary metamorphic-hydrothermal fluids. The presence of a metamorphic-hydrothermal system throughout much of northern Idaho at this time is well documented (Criss et al., 1984; Criss and Fleck, 1987, 1989a,b, 1990; Fleck and Criss, 1985; Constantopoulos, 1994). This model holds that $\mathrm{Sr}$, as well as most other components of the veins (the carbonate, the base- and precious-metals, and the $\mathrm{Fe}, \mathrm{Mn}$, and $\mathrm{Ca}$ ), were leached by the fluids from the Belt wall rocks prior to and during emplacement of the veins. The Sr, the Fe-rich carbonate, and the ore minerals were subsequently deposited from these fluids in veins that grew progressively, probably from their margins to their centers. The high- ${ }^{18} \mathrm{O}$ fluids clearly underwent extensive exchange with the metasedimentary rocks of the Belt Supergroup, and most likely represent ordinary metamorphic or formation fluids with little or no contribution from magmatic sources. This absence of a significant igneous component in the fluids is consistent with $\mathrm{Pb}$ isotope results for Coeur d'Alene ores (Zartman and Stacey, 1971) and makes magmatic fluids, such as from the Gem stocks, improbable sources for the metals.

\section{Unexposed Archean Basement}

Rosenberg and Larson (1996) suggest that veins of the Coeur d'Alene district may have been derived from "older pre-Belt rocks that were already ${ }^{87} \mathrm{Sr} r$-rich a billion years ago". To satisfy this model, a source terrane older than $2500 \mathrm{Ma}$ would need to have $\mathrm{Rb} / \mathrm{Sr}$ values approaching the high values of the Belt Supergroup. Results of Sr studies of Precambrian crystalline rocks west of the Purcell Trench (Armstrong et al., 1987) and Archean rocks east of the Belt basin (James and Hedge, 1980; Henry et al., 1982; Wooden and Mueller, 1988; Mock et al., 1988; Mueller et al., 1993) provide a comparison of ${ }^{87} \mathrm{Sr} /{ }^{86} \mathrm{Sr}$ and $\mathrm{Rb} / \mathrm{Sr}$ in pre-Belt basement to those observed in Belt strata (Table 4). Calculated for a growth over 850 m.y. (Fig. 9), 
${ }^{87} \mathrm{Sr} /{ }^{86} \mathrm{Sr}$ values of these Archean or Early Proterozoic rocks would have been far below the range of values found in Coeur d'Alene veins. Although the Archean rocks are 1000 to 1500 m.y. older than the Belt rocks, their present-day ${ }^{87} \mathrm{Sr} /{ }^{86} \mathrm{Sr}$ values do not approach those of present Belt strata. Consequently, those rocks could not have been the source of high ${ }^{87} \mathrm{Sr} /{ }^{86} \mathrm{Sr}$ today, let alone 800 to $1000 \mathrm{~m}$.y ago (Fig. 9). Considering the range of ${ }^{87} \mathrm{Sr} /{ }^{86} \mathrm{Sr}$ in Archean rocks exposed in the region, arguments suggesting an Archean basement source for the vein $\mathrm{Sr}$ are not supported. Measured values of ${ }^{87} \mathrm{Sr} /{ }^{86} \mathrm{Sr}$ consistently above 1.0 are only obtained from high$\mathrm{Rb} / \mathrm{Sr}$, sedimentary or metasedimentary units in which ${ }^{87} \mathrm{Rb}$ has decayed for 1000 m.y. or more prior to $\mathrm{Sr}$ mobilization. The high $\delta^{18} \mathrm{O}$ values of the veins clearly reflect fluids equilibrated with metasedimentary sources (Criss and Fleck, 1987, 1990; Constantopoulos and Larson, 1991; Eaton et al., 1995). Clearly, the carbonate that represents 50-95 percent of the gangue in many Coeur d'Alene vein systems was derived from an originally sedimentary source. In the Coeur d'Alene region, only rocks of the Belt Supergroup meet these criteria as the source for the carbonate vein systems (Fleck and Criss, 1985; Criss and Fleck, 1987).

Further evidence for the type of crust beneath the Coeur d'Alene district is provided by Sr measurements of the Gem stocks (Table 5). As shown in numerous studies (e.g., Kistler and Peterman, 1973; Armstrong et al., 1977; Fleck and Criss, 1985), initial ${ }^{87} \mathrm{Sr} /{ }^{86} \mathrm{Sr}$ ratios of plutons commonly represent the average isotopic composition of their sources. Initial ${ }^{87} \mathrm{Sr} /{ }^{86} \mathrm{Sr}$ ratios of the Gem stocks are about 0.7053 , whereas most Mesozoic or younger plutons intruding Proterozoic or older crust commonly have ratios $>0.706$ (Kistler and Peterman, 1973; Armstrong et al., 1977, 1987; Farmer and DePaolo, 1983, 1984; Fleck and Criss, 1985). The only other plutons emplaced through Precambrian crust in this region with such anomalously low ${ }^{87} \mathrm{Sr} /{ }^{86} \mathrm{Sr}$ values are Eocene quartz monzonite and granite bodies that extends westward from Lake Pend Oreille (Idaho) into northeastern Washington (Table 5). These are described by Whitehouse et al. (1992), who interpret Nd and U-Pb results as indicating a depleted, Late Archean or Early Proterozoic, lower-crustal source. Like their $\mathrm{Sr}$ initial ratios, feldspar $\mathrm{Pb}$-isotope ratios of these plutons are anomalously low and strikingly similar to those of Coeur d'Alene galenas (Zartman 
and Stacey, 1971). These values suggest similarities in crustal sources for the Eocene plutons and the Gem stocks that are distinct from those of the Wyoming craton or the Spokane dome (Farmer and DePaolo, 1983, 1984; Armstrong et al., 1987; Wooden and Mueller, 1988; Mueller et al., 1988; Wooden et al., 1988; Whitehouse et al, 1992). None of these results suggests that any Archean rocks present as basement to the Belt Supergroup in the Coeur d'Alene district have ${ }^{87} \mathrm{Sr} /{ }^{86} \mathrm{Sr}$ values sufficiently high to be the source for the $\mathrm{Sr}$ in the Coeur d'Alene veins in Proterozoic or even Tertiary time.

The presence of a substantial Archean crust beneath the Coeur d'Alene district is also questioned by $\mathrm{Nd}$ and $\mathrm{U}-\mathrm{Pb}$ studies of the northeastern Idaho batholith, which intrudes rocks of the Belt Supergroup in the southern part of the Belt basin. Mueller et al. (1995) report Nd model ages of 1720 to $2170 \mathrm{Ma}$ for these plutons, suggesting an Early Proterozoic crustal residence for the source. Although the presence of a subordinate Archean component cannot be eliminated, it is largely masked by Early Proterozoic elements. U-Pb studies of single zircons from these plutons using the SHRIMP ion microprobe also indicate dominance of an Early Proterozoic source of the magmas. An upper intercept U-Pb age of $1743 \pm 43 \mathrm{Ma}$ was calculated from these analyses, which appeared to represents a single, coherent population. Mueller et al. (1995) interpret these results as closely representing the age of the predominant source of the magmas in the region. Foster and Fanning (1997) obtained similar SHRIMP results from plutons in this area, concluding that the age of the primary source of plutons of this region was about $1750 \mathrm{Ma}$. These results make the presence of any substantial Archean source under the Coeur d'Alene district and at least the southern part of the Belt basin improbable.

\section{Metasomatic Exchange of Sr in Carbonate Veins}

Unequivocal evidence for metasomatic mobilization of $\mathrm{Sr}$ in the Coeur d'Alene district in the Mesozoic or later is found both in carbonate veins and wall rocks of the Belt Supergroup.

The enormous scale of the metamorphic-hydrothermal system associated with the Idaho batholith in Cretaceous and early Tertiary time is well documented (Criss et al., 1984; Fleck and 
Criss, 1985; Criss and Fleck, 1987, 1989a,b, 1990). The process operated from the scale of intergranular exchange to large-scale fracture flow. First, as documented here, measured ${ }^{87} \mathrm{Sr} /{ }^{86} \mathrm{Sr}$ ratios of low- $\mathrm{Rb}$ carbonate veins are as high as 1.6 , similar to the highest values measured in high-Rb, low-Sr argillite of the Belt Supergroup (Table 3). Second, Rb-Sr studies document the redistribution of radiogenic ${ }^{87} \mathrm{Sr}$ in Belt strata (Obradovich and Peterman, 1968; Fleck and Criss, 1985; Criss and Fleck, 1987; 1990). Model ages of high-Rb/Sr argillites are substantially lower than the presumed 1400-1500 Ma age of the strata, whereas those of low $\mathrm{Rb} / \mathrm{Sr}$ quartzites or limestones may be much older (Table 3). Errorchrons for Belt clastic rocks flatten at high $\mathrm{Rb} / \mathrm{Sr}$, but even lower $\mathrm{Rb} / \mathrm{Sr}$ data may define apparent ages less than the presumed age.

Finally, analysis of a 500-g limestone nodule contained in high- $\mathrm{Rb} / \mathrm{Sr}$ shale of the Wallace Formation near Osburn (Fig. 1) confirms the increase in ${ }^{87} \mathrm{Sr} /{ }^{86} \mathrm{Sr}$ in low-Rb/Sr Belt carbonate rock (sample 918-13C, Table 3) during metamorphism. Because the small-volume nodule was completely enclosed in high- $\mathrm{Rb}$, low-Sr shale during the hydrothermal event, metasomatic effects were expected, but the limestone exhibits no significant textural or fabric evidence of metasomatism. Analyses reveal, however, a measured ${ }^{87} \mathrm{Sr} /{ }^{86} \mathrm{Sr}$ of 0.768 for this sample, compared to a value for Proterozoic seawater of less than 0.710 (e.g., Obradovich and Peterman, 1968; Veizer et al., 1983; Veizer, 1989; Mirota and Veizer, 1994). The low Rb/Sr ratio of this limestone of 0.055 yields a model age in excess of $10 \mathrm{Ga}$ and clearly documents the presence of fluid-derived ${ }^{87} \mathrm{Sr}$. The enclosing shale of the Wallace Formation (sample 918-13D) yields a measured ${ }^{87} \mathrm{Sr} /{ }^{86} \mathrm{Sr}$ of 0.91182 , an ${ }^{87} \mathrm{Rb} /{ }^{86} \mathrm{Sr}$ of 14.9 , and an apparent age of about 850 Ma. The absence of Sr isotopic equilibrium between the limestone and surrounding shale documents the open-system behavior of the rocks expected in metasomatism.

Considering the evidence of substantial metasomatism of Belt strata, is it possible that carbonate veins formed in Proterozoic time obtained their high ${ }^{87} \mathrm{Sr} /{ }^{86} \mathrm{Sr}$ ratios during Mesozoic metasomatism? Although ample evidence of Sr mobility exists, metasomatism of pre-Mesozoic veins by high ${ }^{87} \mathrm{Sr} /{ }^{86} \mathrm{Sr}$ fluids cannot explain the enormous ${ }^{87} \mathrm{Sr} /{ }^{86} \mathrm{Sr}$ ratios of Coeur d'Alene 
veins. Several lines of evidence preclude this origin for the majority of the ore veins. First, the ${ }^{87} \mathrm{Sr} /{ }^{86} \mathrm{Sr}$ of the veins ranges from 0.74 to 1.64 with a mean for all sampled veins over 1.00 and a median of 0.96 . Metasomatism increased the ${ }^{87} \mathrm{Sr} /{ }^{86} \mathrm{Sr}$ in the limestone nodule (Table 3) to 0.768 , but even this special circumstance did not produce values approaching 0.8 .

Secondly, stable isotope co-variations within the veins reflect primary hydrothermal characteristics, not the homogenizing effects of metasomatism. The quasi-linear covariation of $\delta^{18} \mathrm{O}$ and $\delta^{13} \mathrm{C}$ that characterizes hydrothermal deposits is not overprinted by metasomatic homogenization. Increased wall rock $\delta^{18} \mathrm{O}$ adjacent to the high- $\delta^{18} \mathrm{O}$ veins also argues against post-depositional metamorphism of these veins, pointing instead to advection of hotter, deeper fluids producing conditions of isotopic disequilibrium (Eaton et al., 1995). Harris et al. (1981) found that $\delta^{34} \mathrm{~S}$ also exhibits primary hydrothermal variations in the Sunshine mine, including at least local variation with depth.

Most importantly, detailed sampling profiles across Coeur d'Alene ore veins (Eaton et al., 1995) have demonstrated an enormous, isotopically correlated, centimeter-scale variation in $\delta^{18} \mathrm{O}, \delta^{13} \mathrm{C}, \mathrm{Sr}$, and ${ }^{87} \mathrm{Sr} r{ }^{86} \mathrm{Sr}$ (Fig. 5,6). These correlated isotopic variations are conclusive evidence that the veins exhibit primary hydrothermal character that has not been homogenized by metamorphism. These veins record progressive, time-dependent, incremental growth patterns and abrupt changes in their chemical and isotopic composition, representing changes in the character of the fluids during deposition. Regional metamorphism involving large-scale, metasomatic introduction of $\mathrm{Sr}$ (and other components) into these veins subsequent to deposition almost certainly would have caused homogenization of the primary isotopic variations of both radiogenic and stable isotopic systems. If the veins had formed in the Proterozoic and the high ${ }^{87} \mathrm{Sr} /{ }^{66} \mathrm{Sr}$ ratios established during Mesozoic and Tertiary metasomatism, those isotopic ratios would have been much more uniform across the veins. Although leaching of wall rocks, exchange with solid phases, and some homogenization clearly occurred at an intergranular scale during the Mesozoic or younger metamorphic-hydrothermal event, primary deposition of $\mathrm{Sr}$ bearing ore veins in through-going fracture systems is required by the results. 


\section{Interpretation of Sr Results}

Strontium, oxygen, and carbon isotopic ratios provide strong constraints on the age, source, and mode of origin of most of the Coeur d'Alene veins. Highly radiogenic Sr, metasedimentary stable-isotope signatures, and most of the metals deposited in the ore veins were derived from sources within the Belt Supergroup during a metamorphic-hydrothermal episode in Mesozoic or younger time. Carbonate-rich ore veins were deposited from thermally driven fluids that scavenged these components from the Belt strata. Evidence for the metamorphic-hydrothermal system that existed throughout much of northern Idaho in late Mesozoic and early Tertiary time and was probably responsible for Coeur d'Alene vein mineralization was discussed earlier (Criss et al., 1984; Fleck and Criss, 1985; Criss and Fleck, 1987, 1989a,b, 1990; Leach et al., 1988; Constantopoulos, 1994).

Leach et al. (1998a) argue that many $\mathrm{Pb}-\mathrm{Zn}$ veins of the Coeur d'Alene district formed in the Proterozoic, but do not exclude possible mobilization of strata-bound deposits during the Mesozoic. In veins where the ${ }^{87} \mathrm{Sr} /{ }^{86} \mathrm{Sr}$ ratios of the carbonate phases are less than about 0.78 , that possibility cannot be discounted. To be so, however, one must accept either that the folds and faults occupied by both Proterozoic and Mesozoic/Early Tertiary veins formed in the Proterozoic or that the old structures and their veins were not folded or otherwise deformed seriously during any subsequent deformation. We consider both possibilities unlikely. Abundant evidence of intense Mesozoic-Cenozoic deformation, metamorphism, intrusion, and hydrothermal activity contrasted with indications of gentle folding and tilting in the Proterozoic (Harrison, 1986) suggests that most of the vein-controlling structures and both types of veins formed in Mesozoic or younger time. Based on evidence cited and interpretations presented by Wells (1974), White (1998a), and White et al. (2000b), a Mesozoic age for the folding and thrust faulting appears most likely. Only 30 miles to the east of the Coeur d'Alene district in Montana apparently synchronous thrust faults and folds with styles and trends typical of the district deform the disconformable but concordant contacts between Cambrian rocks and Proterozoic 
Belt strata. In our view this evidence precludes a Proterozoic age for any significant folding or thrust faulting and is consistent with a Mesozoic or younger age for the major folds, faults, and ore-bearing veins contained within them in the Coeur d'Alene mining district (White, 1998a).

\section{INTERPRETATION OF Pb AND Ar RESULTS}

As discussed earlier, conflicting results from $\mathrm{U}-\mathrm{Pb}, \mathrm{K}-\mathrm{Ar}$, and Ar-Ar studies of Coeur d'Alene veins permit the interpretation that some of the veins were emplaced in Proterozoic time (Kerr and Kulp, 1952; Kerr and Robinson, 1953; Eckelmann and Kulp, 1957; Long et al., 1960; Silverman et al., 1960; Cannon et al., 1962; Zartman and Stacey, 1971; Leach et al. 1988; 1998a,b; Zartman and Smith, 1995). Without the strong structural evidence to the contrary, the model of Proterozoic and Mesozoic vein-forming episodes suggested by Leach et al. (1998a,b) cannot be discounted completely despite irrefutable $\mathrm{Sr}$ isotope evidence that most vein systems in the Coeur d'Alene mining district are Mesozoic or younger. Because geologic evidence constrains the structures occupied by the vein systems to be Paleozoic or younger (White, 1998a; White et al., 2000b), however, lead and argon isotopic results indicating a Proterozoic age require explanation.

\section{$\underline{\mathrm{Pb} \text { Isotope Studies }}$}

Isotopic evidence indicates that most of the $\mathrm{Pb}$ in veins of the Coeur d'Alene district was separated from U between 1500 and $1200 \mathrm{Ma}$, at or near the time of Belt sedimentation (Long et al., 1960; Cannon et al., 1962; Zartman and Stacey, 1971; Aleinikoff et al., 1996). This so-called "Coeur d'Alene-type" $\mathrm{Pb}$ was most likely separated from uranium during or shortly after the 1400- to 1500-Ma deposition of Belt strata. The model most consistent with isotopic results is that $\mathrm{Pb}$ and other base metals were deposited with the earliest Belt sediments as syngenetic, sediment-hosted, massive sulfide deposits. Following suggestions by Zartman and Stacey (1971), Leach et al. (1998a) also conclude that stratiform lead-zinc deposits were formed during Belt sedimentation, but they propose that Coeur d'Alene veins formed at about $1000 \mathrm{Ma}$. 
Although stratiform mineralization has been described at the Bunker Hill and Lucky Friday mines (Vulimiri and Cheney, 1981; Ramalingaswamy and Cheney, 1982; White, 1998b), these deposits are probably not syngenetic, but controlled by sedimentary structures, susceptibility to cataclasis, permeability, and proximity to major vein systems (Reid, 1982; White, 1998b). Although not identified in the district, syngenetic, sediment-hosted, massive sulfide deposits, such as occur within Belt-equivalent strata at Sullivan, British Columbia (e.g., Beaudoin, 1997), are the most likely sources of $\mathrm{Pb}$ in the Coeur d'Alene district because of the synchronism of sedimentation and isolation of significant amounts of $\mathrm{Pb}$ from uranium. Neither $\mathrm{U}-\mathrm{Pb}$ or $\mathrm{Pb}$ isotopic evidence indicates vein formation in the Coeur d'Alene district at $1000 \mathrm{Ma}$.

During formation of the Coeur d'Alene veins, hydrothermal fluids almost certainly scavenged $\mathrm{Sr}$ and $\mathrm{Pb}$ from both radiometrically evolved Belt strata and radiometrically retarded stratiform deposits or marine limestones. Clearly, the $\mathrm{Pb}$ budget in ore-fluids derived from syngenetic deposits containing Belt-age galena with nearly 87 percent $\mathrm{Pb}$ by weight will be dominated by isotopically retarded Proterozoic $\mathrm{Pb}$. Zartman and Stacey (1971) argue that mobilizing stratiform $\mathrm{Pb}$ into veins close to its age of deposition would result in much less contamination of the veins by radiogenic $\mathrm{Pb}$ from the Belt strata than after 1400 to $1000 \mathrm{~m}$.y. Although valid, the amount of $\mathrm{Pb}$ formed in Belt strata by the decay of less than about $6 \mathrm{ppm}$ uranium at virtually any age will show little effect on $\mathrm{Pb}$ from stratiform galena. $\mathrm{Pb}$ with an isotopic composition established in the Proterozoic only establishes a maximum age for mineralization, unless related genetically to vein formation. "Coeur d'Alene-type" $\mathrm{Pb}$ could have been mobilized from a Proterozoic massive-sulfide source at any time from approximately $1450 \mathrm{Ma}$ to the present, based on the age of the Belt Supergroup.

Zartman and Stacey (1971) report many Pb-bearing ore deposits emplaced in Belt strata throughout northwestern Montana and northern Idaho that were undoubtedly deposited in Mesozoic or Cenozoic time, based on their much more radiogenic $\mathrm{Pb}$-isotope compositions. These deposits are scattered geographically and interspersed with deposits characterized by Proterozoic Pb (Zartman and Stacey, Fig. 2, 1971). Deposits dominated by Proterozoic Pb, 
however, appear to be strongly localized by a north-trending lineament, called the Noxon line or arch by White and Applegate (2000). White and Applegate (2000) argue that faulting along the Noxon line controlled the deposition of syngenetic $\mathrm{Pb}-\mathrm{Zn}-\mathrm{Ag}$ ore bodies from the Sullivan mine in British Columbia south to the Coeur d'Alene district, where the arch intersects the Lewis and Clark line. This intersection was represented as a "structural knot" by Wallace et al. (1960), who also note that the Gem stocks were emplaced into this structure. Mesozoic and early Tertiary magmatism and tectonism subsequently produced a geographic intermingling of ore deposits in the region, forming ore bodies with significant radiogenic $\mathrm{Pb}$ away from the Noxon arch and ones dominated by remobilized, Coeur d'Alene-type, retarded $\mathrm{Pb}$ along the arch where it was deposited originally in the Proterozoic (Zartman and Stacey, 1971; White and Applegate, 2000).

Until recently, Proterozoic ages assigned to Coeur d'Alene veins were based primarily on 1000-1200 Ma ages obtained for uranium-bearing jasper veins in the Sunshine mine (Kerr and Kulp, 1952; Kerr and Robinson, 1953; Eckelmann and Kulp, 1957; Silverman et al., 1960; Long et al., 1960; Leach et al., 1988, 1998a,b). Zartman and Smith (1995) eliminated this constraint with their study of uranium-bearing veins of the Sunshine mine, establishing the age of the Ubearing mineral, brannerite, and that of co-existing zircon and pyrite as $133 \pm 6 \mathrm{Ma}$. These results not only remove any requirement of a Proterozoic age, but constrain the age of the younger, siderite-tetrahedrite veins of the Sunshine Mine to Cretaceous or younger, in so far as they crosscut the uranium-bearing veins (Kerr and Robinson, 1953).

Leach et al. (1998a,b) report $\mathrm{Pb}$ isotope ratios for siderite and tetrahedrite from the Sunshine, Galena, and Hypotheek mines that are much more radiogenic than galena from the same vein systems. Adding measurements of highly radiogenic $\mathrm{Sr}$ in Sunshine and Galena mine siderites (Table 1) to the $\mathrm{Pb}$ results of Leach et al. (1998a,b) and Cannon et al (1962) extends this paradox by analogy to the Gold Hunter, Lucky Friday, and Highland Surprise mines. The $\mathrm{Pb}$ isotopic compositions of galena and tetrahedrite from these vein systems preclude their simultaneous deposition from the same fluids. This apparent isotopic disequilibrium must be explained by either spatially, mechanically, or temporally separate emplacement of these ores. 
Leach et al. (1998a,b) emphasize a bimodal character of Coeur d'Alene veins, concluding that $\mathrm{Pb}-\mathrm{Zn}$ veins formed in the Proterozoic, whereas Ag-rich, siderite-tetrahedrite veins were deposited in Mesozoic/Cenozoic time. This interpretation would require that the vein systems in at least these six mines include veins formed almost $1000 \mathrm{~m} . \mathrm{y}$. apart, occupying the same, almost certainly Paleozoic or younger, geologic structures (White, 1998a). Conversely, abundant evidence cited above suggests that most of the structures and both types of veins formed in Mesozoic or younger time. Hobbs et al (1965) demonstrated this conclusively for the Puritan fault (Fig. 1), for which substantial displacement juxtaposes unmetamorphosed Prichard against monzonite of the North Gem stock. The Puritan fault localized concentrations of ore sufficient for mining over a vertical distance of 1000 feet in the Tamarack mine, yet fault movement subsequent to ore emplacement was considered minor by Hobbs et al. (1965).

Although the $\mathrm{Pb}$ isotopic differences indicate that most $\mathrm{Pb}-\mathrm{Zn}$ and siderite-tetrahedrite mineralization was derived from different sources, they do not constrain the timing of vein formation. Although $\mathrm{Pb}$ with "Coeur d'Alene-type" isotopic ratios indicates an originally Proterozoic source, evidence suggests that galena in Coeur d'Alene veins was almost always introduced late in the paragenetic sequence (e.g. Hershey, 1916; Fryklund, 1964). As would be expected from the absence of Proterozoic $\mathrm{Pb}$ contamination found in the tetrahedrite by Leach et al. (1998a), galena following siderite-tetrahedrite is the most commonly observed paragenetic sequence where both mineral associations occur (Fryklund, 1964; Brian White, written comm., 2000). Analyses of siderite from sample profiles across siderite-tetrahedrite veins reveal extreme variations in ${ }^{87} \mathrm{Sr} /{ }^{86} \mathrm{Sr}$, demonstrating that layers were deposited sequentially. Extending these observations to the paragenetic sequences of the veins, suggests that not only were different metallic mineral species deposited at different times, but that metal such as $\mathrm{Pb}$ from different sources was also deposited sequentially. This would be especially true if the Coeur d'Alene-type $\mathrm{Pb}$ were derived from syngenetic sediment-hosted massive sulfides that were low in $\mathrm{Ag}$ and $\mathrm{Cu}$, favoring galena over tetrahedrite deposition. We suggest that the vein systems of the Coeur d'Alene district formed in Mesozoic or younger time in multiple ore-forming pulses involving 
fluids derived from or passing through different sources within the Belt Supergroup with extremely different $\mathrm{Sr}$ and $\mathrm{Pb}$ isotopic compositions. At least one of these sources probably included syngenetic, stratiform $\mathrm{Pb}-\mathrm{Zn}$ deposits.

\section{Argon Geochronology in the Coeur d'Alene District}

$\mathrm{K}-\mathrm{Ar}$ and Ar-Ar apparent ages of muscovite and phlogopite from veins of the Coeur d'Alene mining district range from $1018 \mathrm{Ma}$ to $<74 \mathrm{Ma}$ with a spectrum of intermediate values that is far from bimodal (Leach et al., 1988, 1998a; Rosenberg and Larson, 1996). Leach et al., (1998a) present data for an even-younger muscovite from altered wall rock adjacent to a vein outside the district (ca. $64 \mathrm{Ma}$, Baychief mine). In this latter case, wall-rock muscovite has clearly been reset from an earlier detrital, diagenetic, or burial-metamorphic age, but what is the origin of muscovite found in Coeur d'Alene veins? Leach et al. (1998a) report a disturbed Ar-Ar age spectrum for muscovite from the Lucky Friday mine they interpret as reflecting argon loss and a minimum age of $1018 \mathrm{Ma}$. They interpret this as evidence of a Proterozoic vein-forming event at about $1000 \mathrm{Ma}$, during which muscovite (sericite) formed in the vein. Paradoxically, Lucky Friday veins also yield siderite with ${ }^{87} \mathrm{Sr} /{ }^{86} \mathrm{Sr}$ of $0.833-0.857$ (Table 1). Belt strata with a median ${ }^{87} \mathrm{Rb} /{ }^{86} \mathrm{Sr}$ (Table 3) would require about $750 \mathrm{~m}$.y. to generate an ${ }^{87} \mathrm{Sr} /{ }^{86} \mathrm{Sr}$ of $0.833-0.857$. With an age of $1440 \mathrm{Ma}$ for the Belt strata, this could not be achieved until $690 \mathrm{Ma}$, long after the apparent age of the muscovite. The physical relationship between the rifuscovite and the siderite samples is not known, but the minimum age indicated for the mica is not consistent with its primary crystallization from the siderite-bearing veins.

A possible explanation of this paradox is that muscovite-bearing wall rock adjacent to major veins such as the Lucky Friday vein has been incorporated into the mineralized zones as ore fluids spread outward from the primary vein systems and vein minerals were deposited within the sheared wall rock. Reid (1982) reports petrographic study of this process for the Bunker Hill mine, where 10 percent of the rock was sericite and galena was about 5 percent. Fryklund (1964) found that muscovite was present in the veins as both "a constituent of 
unreplaced country rock and as recrystallized material". The mica may have formed within Belt strata during Proterozoic burial metamorphism, perhaps during periods of elevated thermal gradient that may have accompanied orogenic events recognized in British Columbia (McMechan and Price, 1982; Anderson and Davis, 1995; Doughty et al., 1998). Alternatively, the muscovite could have been formed in bedding-parallel veins during burial metamorphism of the pelitic sediments, folded and faulted prior to mineralization, and incorporated into Coeur d'Alene mineralization in the same passive way as any of the incompletely replaced country rock.

The Ar-Ar age spectrum of muscovite from the Lucky Friday vein reported by Leach et al. (1998a) is consistent with Mesozoic or younger Ar loss due to temperatures that exceeded its Ar closure-temperature, which averages about $325^{\circ} \mathrm{C}$ (Snee et al., 1988; Hames and Hodges, 1993). This Ar loss could have occurred when muscovite in "unreplaced country-rock" adjacent to the Lucky Friday vein was saturated by the mineralizing fluids and incorporated into the ore. Leach et al. (1988) subdivide fluid-inclusions in Coeur d'Alene veins into three types, based on the phase state and chemical composition of their fluids. They found that homogenization temperatures of their Type 1 inclusions, including some from the Lucky Friday mine, were in the range of $225^{\circ}$ to $300^{\circ} \mathrm{C}$. They suggest that actual trapping temperatures may be as much as 50$100^{\circ} \mathrm{C}$ higher at $0.1 \mathrm{Gpa}(1 \mathrm{kbar})$ pressure. Hames and Hodges (1993) calculate minimum and maximum Ar closure temperatures for $1 \mathrm{~mm}$ muscovite grains of $253^{\circ}$ and $392^{\circ} \mathrm{C}$, respectively, suggesting significant Ar loss could have occurred near crystal rims. Cores of grains may have suffered minimal Ar loss, however, as the grains were neither recrystallized or replaced. Clearly, temperatures in the veins could have been either above or below the approximate closuretemperature for Ar in muscovite. Soaked with hydrothermal fluids at temperatures of $225^{\circ}$ to $400^{\circ} \mathrm{C}$, muscovite could lose large or small amounts of its pre-existing radiogenic Ar, depending on the temperature of the fluid and its rate of cooling. Temperatures would be lower and cooling would be faster with increasing distance into the wall rock from the primary vein. 
Whole-rock K-Ar apparent ages of muscovite- or sericite-dominated Belt metasedimentary rocks range from $45 \mathrm{Ma}$ near the Idaho batholith to values of $1033 \mathrm{Ma}$ near Avery, Idaho (Armstrong, 1976). The rocks near Avery not only yield apparent ages as high as $1033 \mathrm{Ma}$, but values as low as $189 \mathrm{Ma}$ are measured only a few miles away (Armstrong, 1976). An age of $530 \mathrm{Ma}$ at the Silver Summit mine in the Coeur d'Alene district is reported by Armstrong (1976). This pattern of variable apparent ages is typical of metamorphic terranes and nearly identical to that of muscovites from Coeur d'Alene veins, as shown in Figure 1 of Leach et al. (1998b). This distribution is characteristic of Ar loss from the rocks subjected to temperatures near or slightly above their Ar closure-temperatures or where temperatures vary over short distances due to the distribution of more local heat sources, such as veins or dikes.

Vein muscovites from the Sunshine mine that yield a K-Ar apparent age of $77 \pm 5-\mathrm{Ma}$ (Leach et al., 1988) and a gently sloping, Ar-Ar age spectrum with an 85-Ma total-gas age (Leach et al., 1998a) indicate a Late Cretaceous or younger cooling of these veins. Whether these results represent nearly complete resetting of incorporated muscovite or primary growth of muscovite in the vein followed by mild reheating is not established, but the continuum of disturbed ages from $1018 \mathrm{Ma}$ to $64 \mathrm{Ma}$ favors the former. Although temperatures of the siderite veins in the Coeur d'Alene district may have exceeded $325^{\circ}$ to $350^{\circ} \mathrm{C}$ locally, temperatures in local Belt rocks outside the veins commonly did not reach these temperatures. Metamorphic temperatures in the most deeply buried strata may have reached those of the biotite zone, but sericitic alteration of clays is generally the limit of local metamorphism (Hobbs et al., 1965). Although their mode of origin may be ambiguous, the Cretaceous apparent ages of some of these micas confirm Mesozoic or younger vein formation in the district. In our view, however, the significance of the Proterozoic Ar-Ar ages of vein muscovites remains uncertain.

\section{CONCLUSIONS}

Results of $\mathrm{Sr}$ isotopic studies of carbonate-dominant veins and associated $\mathrm{Pb}$ and $\mathrm{Ag}$ ores of the Coeur d'Alene mining district indicate that the majority of these veins were deposited in 
Cretaceous or early Tertiary time, consistent with structural evidence requiring a Paleozoic or younger age for unfolded veins. Ore-forming fluids were driven by metamorphic-hydrothermal system associated with Cretaceous or Early Tertiary deformation and plutonism that included the Idaho and Kaniksu batholiths and their precursors (Criss and Fleck, 1990). These fluids scavenged metals from Proterozoic concentrations in the strata of the Belt Supergroup that may include undiscovered Sullivan-type syngenetic $\mathrm{Pb}-\mathrm{Zn}$ deposits. Monzonite intrusive rocks of the Gem stocks probably represent minor perturbations of the thermal regime and are largely unrelated to the ore bodies. The ore-forming fluids were not derived from the Gem stocks and only minor igneous contributions are permissible given the stable and radiogenic isotope results (Criss and Fleck, 1990; Eaton et al., 1995). Radiogenic $\mathrm{Pb}$ in siderite and tetrahedrite from Agrich veins confirms the $\mathrm{Sr}$ isotope results, which indicate a Cretaceous or early Tertiary age for the Coeur d'Alene veins. Zartman and Smith (1995) have demonstrated that uranium-bearing jasper veins that predate the base- and precious-metal veins in the Sunshine mine are actually Early Cretaceous in age, not 1000-1190 Ma, as suggested by earlier workers.

Although many recent authors have invoked Proterozoic vein-forming mineralization in the Coeur d'Alene district, Cretaceous veins occupying the same structures with those of Proterozoic age and not being structurally distinct questions this conclusion. A Paleozoic or younger age is indicated for the folds and faults that contain the generally sub-planar morphology of the veins and undeformed veins of Proterozoic age are considered improbable. We find a model involving tectonic and hydrothermal re-mobilization of Proterozoic stratiform $\mathrm{Pb}-\mathrm{Zn}$ deposits during the Cretaceous or early Tertiary event more credible. Isotopic results from galena- and calcite/ankerite-rich veins with high $\mathrm{Pb}$ and $\mathrm{Sr}$ concentrations are often ambiguous because of inherited "common" $\mathrm{Sr}$ and $\mathrm{Pb}$. Just as Belt strata most likely contain a potential stratiform $\mathrm{Pb}$ reservoir for non-radiogenic "Coeur d'Alene-type" $\mathrm{Pb}$, Belt limestones and calcareous clastic rocks are also reservoirs of Proterozoic non-radiogenic $\mathrm{Sr} .{ }^{87} \mathrm{Sr} /{ }^{86} \mathrm{Sr}$ values less than about 0.72 in vein carbonates would be consistent with vein formation in Proterozoic 
time, but Mesozoic metasomatic effects could elevate these values to as much as 0.78 , making age interpretations of such measurements ambiguous without other constraints.

$\mathrm{K}-\mathrm{Ar}$ and Ar-Ar apparent ages of some vein muscovites are consistent with Proterozoic vein formation, but high ${ }^{87} \mathrm{Sr} /{ }^{86} \mathrm{Sr}$ in siderite from the same vein systems questions the coeval formation of the vein minerals. Although Late Cretaceous Ar-Ar apparent ages confirm the $\mathrm{Sr}$ and $\mathrm{Pb}$ isotope evidence of Mesozoic or younger mineralization, some of the Ar-Ar age spectra indicate Ar loss after Proterozoic crystallization. We acknowledge the paradox of Proterozoic Ar-Ar apparent ages on muscovite from ores that yield highly radiogenic $\mathrm{Sr}$ and $\mathrm{Pb}$, but must conclude that wall rock mica, formed in Proterozoic time during earlier burial and metamorphism, was incorporated by Cretaceous or younger veins. As indicated by fluid inclusion studies, vein temperatures below the Ar blocking temperature of muscovite were common, permitting retention of pre-emplacement radiogenic Ar under those circumstances.

Evidence for important Cretaceous or younger $\mathrm{Pb}-\mathrm{Ag}$ mineralization in the Coeur d'Alene mining district is unequivocal. Proterozoic mineralization is well documented in Beltequivalent strata in British Columbia, but related ore bodies are most commonly described as stratiform, syngenetic, or sediment-hosted massive sulfide deposits, typified by the Sullivan-type ores (e.g. Beaudoin, 1997). Evidence for Proterozoic deformation in central Idaho and adjacent British Columbia has been documented (McMechan and Price, 1982; Evans and Fischer, 1986; Anderson and Davis, 1995; Doughty et al., 1998), although effects in northern Idaho and adjacent Montana are either minimal or unrecognized (Harrison, 1986; White 1998; 2000; White and Applegate, 2000; White et al., 2000b). Disruption, deformation, and re-mobilization of Proterozoic, Sullivan-type, syngenetic deposits into Cretaceous and early Tertiary vein systems during their emplacement could account for the Proterozoic apparent ages and $\mathrm{Pb}$ isotopic signatures. The study by Zartman and Smith (1995) demonstrates the mobility of the Proterozoic $\mathrm{Pb}$, forming an intimate association with uranium-bearing minerals during the Cretaceous and early Tertiary metamorphic-hydrothermal event. We suggest that "Coeur d'Alene-type" $\mathrm{Pb}$ was mobilized from Proterozoic syngenetic deposits and incorporated into Coeur d'Alene veins with 
$\mathrm{Ag}, \mathrm{Sr}$, and a variety of other metals scavenged from strata of the Belt Supergroup by Cretaceous or younger metamorphic-hydrothermal fluids.

\section{ACKNOWLEDGMENTS}

This study is the outgrowth of a stable isotope study kindly authorized and supported by the Sunshine Precious Metals Company. We also received complete cooperation from Hecla Mining Company, operators of the Lucky Friday and Gold Hunter Mines, and American Smelting and Refining and Silver Valley Resources, operators of the Galena, Coeur, and Caladay Mines. These companies provided access, samples, and information on their workings and we extend our appreciation. One of us, Craig S. Wavra, lost his life in an automobile accident far from the Coeur d'Alene district and was unable to participate in the final preparation of this manuscript. His contributions of knowledge, time, enthusiasm, and humor are irreplaceable and greatly missed. We thank Susan Gunn, Betsy Rosenberg, and Robert Vasser for assistance with strontium chemistry and mass spectrometry. We offer a special thanks to Brian White for reviewing the manuscript and for suggestions that greatly improved it. Ron Kistler, Joseph Arth, and Marvin Lanphere reviewed earlier versions of the manuscript and provided helpful suggestions for its improvement. They should not be held liable for any of its shortcomings, however. 


\section{REFERENCES CITED}

Aleinikoff, J.N., Evans, K.V., Fanning, C.M., Obradovich, J.D., Ruppel, E.T., Zieg, J.A., and Steinmetz, J.C., 1996, SHRIMP U-Pb ages of felsic igneous rocks, Belt Supergroup, western Montana: Geol. Soc. America Abstracts With Programs, v.28, no.7, p.376.

Anderson, H.E. and Davis, D.W., 1995, U-Pb geochronology of the Moyie sills, Purcell Supergroup, southeastern British Columbia: Implications for the Mesoproterozoic geologic history of the Purcell (Belt) basin: Can. J. Earth Sci., v.32, p.1180-1193.

Armstrong, R.L., 1976, The geochronometry of Idaho (part 2): Isochron West, v.15, p.1-33.

Armstrong, R.L., Taubeneck, W.H., and Hales, P.O., 1977, Rb-Sr and K-Ar geochronometry of Mesozoic granitic rocks and their Sr isotopic composition, Oregon, Washington, and Idaho: Geol. Soc. America Bull., v.88, p.397-411.

Armstrong, R.L., Parrish, R.R., Van der Heyden, P., Reynolds, S.J., and Rehrig, W.A., 1987, Rb$\mathrm{Sr}$ and U-Pb geochronometry of the Priest River metamorphic complex - Precambrian X basement and its Mesozoic-Cenozoic plutonic-metamorphic overprint, northeastern Washington and northern Idaho: Wash. Div. Geol. and Earth Resources Bull. 77, p.1539.

Beaudoin, G., 1997, Proterozoic Pb isotope evolution in the Belt-Purcell Basin: Constraints from syngenetic and epigenetic sulfide deposits: Econ. Geol., v.92, p.343-350.

Bennett, E.H. and Venkatakrishnan, R., 1982, A palinspastic reconstruction of the Coeur d'Alene mining district based on ore deposits and structural data: Econ. Geol., v.77, p.1851-1866.

Billingsley, P.R. and Locke, Augustus, 1939, Structure of ore deposits in the continental framework: New York, Am. Inst. Mining Metall. Engineers, 51p.

Borthwick, J. and Harmon, R.S., 1982, A note regarding ClF3 as an alternative to BrF3 for oxygen isotope analyses: Geochim. Cosmochim. Acta, v.46, p.1665-1668. 
Cannon, R.S., Pierce, A.P., Antweiler, J.C., and Buck, K.L., 1962, Lead-isotope studies in the northern Rockies, U.S.A.: in Petrologic Studies-A volume in honor of A. F. Buddington: New York, Geol. Soc. America, p.115-131.

Carothers, W.W., Adami, L.H., and Rosenbauer, R.J., 1988, Experimental oxygen isotope fractionation between siderite-water and phosphoric acid-liberated $\mathrm{CO}_{2}$-siderite: Geochim. Cosmochim. Acta, v.52, p.2445-2450.

Clayton, R.N. and Mayeda, T..K., 1963, The use of bromine pentafluoride in the extraction of oxygen from oxides and silicates for isotopic analysis: Geochim. Cosmochim. Acta, v. 27, p.43-52.

Constantopoulos, J., 1994, Oxygen isotope geochemistry of the Coeur d'Alene mining district, Idaho: Econ. Geol., v.89, p.944-951.

Constantopoulos, J. and Larson, P.B., 1991, Oxygen and hydrogen isotope geochemistry of the Star-Morning mine, Coeur d'Alene mining district, Idaho: Geology, v.19, p.131-134.

Criss, R.E., Eaton, G.F., 1998, Evidence for Proterozoic and Late Cretaceous-Early Tertiary oreforming events in the Coeur d'Alene district, Idaho and Montana-a discussion: Econ Geol., v.93, p.1103-1105.

Criss, R.E., Fleck, R.J., and Barnes, I, 1984, Gigantic metamorphic-hydrothermal system around the northern Idaho batholith and its relationship to regional metamorphic zonation: Geol. Soc. Am. Abstracts with Programs, v.16, no. 6, p. 479.

Criss, R.E. and Fleck, R.J., 1987, Geology of the Blue Mountains region of Oregon, Idaho, and Washington: The Idaho batholith and its border zone: U.S. Geol. Survey Prof. Paper 1436, p.95-137.

Criss, R.E. and Fleck, R.J., 1989a, Oxygen isotope map of the $20,000 \mathrm{~km}^{2}$ metamorphic hydrothermal system around the northern Idaho batholith: Geol. Soc. America Abstracts with Programs, v.21, no. 5, p. 70 . 
Criss, R.E. and Fleck, R.J., 1989b, d ${ }^{18}$ O map of the giant metamorphic-hydrothermal system around the northern Idaho batholith: EOS (Am. Geophys. Union Trans.), v.70, no. 43, p. 1379.

Criss, R.E. and Fleck, R.J., 1990, Oxygen isotope map of the giant metamorphic-hydrothermal system around the northern part of the Idaho batholith, U.S.A.: Applied Geochem., v.5, p.641-655.

Doughty, P.T., Price, R.A., and Parrish, 1998, Geology and U-Pb geochronology of Archean basement and Proterozoic cover in the Priest River complex, northwestern United States and their implications for Cordilleran structure and Precambrian continent reconstructions: Can. J. Earth Sci., v.35, p.39-54.

Eaton, G.F., 1993, The stable oxygen and carbon isotope geochemistry of the Sunshine mine, Coeur d'Alene Mining District, Shoshone County, Idaho: M.S. thesis, University of California, Davis, CA.

Eaton, G.F., Criss, R.E., Fleck, R.J., Wavra, C.S., Cleland, R.W., and Bond, W.D., 1992, Oxygen isotope geochemistry of the Sunshine mine, Coeur d'Alene mining district, Idaho: EOS (Am. Geophys. Union Trans.), v.73, no. 43, p.627.

Eaton, G.F., Criss, R.E., and Fleck, R.J., 1993, Isotopic evidence for timing and mechanism of deposition of the $\mathrm{Pb}-\mathrm{Ag}$ veins of the Sunshine mine, Coeur d'Alene district, Idaho: Geol. Soc. America Abstracts With Programs, v.25, no.5, p.33.

Eaton, G.F., Criss, R.E., Fleck, R. J., Bond, W.D., Cleland, R.W., and Wavra, C.S., 1995, Oxygen, carbon, and strontium isotope geochemistry of the Sunshine mine, Coeur d'Alene Mining District, Idaho: Econ. Geol., v.90, p.2274-2286.

Eckelmann, W. R. and Kulp, J.L., 1957, North American localities, Pt. 2 of Uranium-lead method of age determination: Geol. Soc. America Bull., v.68, no.9, p.1117-1140.

Evans, K.V. and Fischer, L.B., 1986, U-Pb geochronology of two augen gneiss terranes, Idaho - new data an tectonic implications: Can. J. Earth Sci., v.23, p.1919-1927. 
Farmer, G.L. and DePaolo, D.J., 1983, Origin of Mesozoic and Tertiary granite in the western United States and implications for pre-Mesozoic crustal structure; 1, Nd and Sr isotopic studies in the geocline of the northern Great Basin: Jour. Geophys. Res., B, v.88, no.4, p.3379-3401.

Farmer, G.L. and DePaolo, D.J., 1984, Origin of Mesozoic and Tertiary granite in the western United States and implications for pre-Mesozoic crustal structure; 2, $\mathrm{Nd}$ and $\mathrm{Sr}$ isotopic studies of unmineralized and $\mathrm{Cu}$ - and Mo-mineralized granite in the Precambrian craton: Jour. Geophys. Res., B, v.89, no.12, p.10,141-10,160.

Fillipone, J.A., Harrison, T.M., Sample, J.C., and Yin, A., 1992, Thermochronological evolution of the Hope and Moyie fault systems, NW Montana and NE Idaho: A progress report: Geol. Soc. America Abstracts With Programs, v.24, no.6, p.11.

Fleck, R.J. and Criss, R.E., 1985, Strontium and oxygen isotopic variations in Mesozoic and Tertiary plutons of central Idaho: Contrib. Mineral. Petrol., v.90, p.291-308.

Fleck, R.J., Criss, R.E., Eaton, G.F., Wavra, C.S., and Bond, W.D., 1991, Strontium and oxygen isotopic characteristics and the age of siderite-tetrahedrite veins in the Sunshine mine, Coeur d'Alene district, Idaho [abs]: Geol. Soc. America Abstracts With Programs, v.23, no.5, p. 173 .

Foster, D.A. and Fanning, C.M., 1997, Geochronology of the northern Idaho batholith and the Bitterroot metamorphic core complex: Magmatism preceding and contemporaneous with extension: Geol. Soc. America Bull., v.109, no.4, p.379-394.

Fryklund, V.C., 1964, Ore deposits of the Coeur d'Alene district, Shoshone County, Idaho: U.S. Geological Survey Professional Paper 445, 103p.

Gott, G.B. and Cathrall, J.B., 1980, Geochemical exploration studies in the Coeur d'Alene district, Idaho and Montana: U.S. Geological Survey Professional Paper 1116, 63p.

Hames, W.E. and Hodges, K.V., 1993, Laser 40Ar/39Ar evaluation of slow cooling and episodic loss of 40Ar from a sample of polymetamorphic muscovite: Science, v.261, Sept 24, p.1721-1723. 
Harris, R.H., Lange, I.M., and Krouse, H.R., 1981, Major element and sulfur isotopic variations in the Lower Chester vein, Sunshine mine, Idaho: Econ. Geol., v.76, p.706-715.

Harrison, J.E., 1972, Precambrian Belt basin of northwest United States: Its geometry, sedimentation, and copper occurrences: Geol. Soc. America Bull., v.83, p.1215-1240.

Harrison, J.E., 1986, Proterozoic folding in Belt terrane of northwestern United States and adjacent Canada, and its effects on Phanerozoic thrusting: Geol. Soc. America Abstracts With Programs, v.18,.no.6, p.629.

Harrison, J.E., Kleinkopf, M.D., and Wells, J.D., 1980, Phanerozoic thrusting in Proterozoic belt rocks, northwestern United States: Geology, v.8, p.407-411.

Harrison, J.E., Griggs, A.B., and Wells, J.D., 1986, Geologic and structure maps of the Wallace $1^{\circ} \times 2^{\circ}$ quadrangle, Montana and Idaho: U.S. Geol. Survey Map I-1509, 1:250,000.

Henry, D.J., Mueller, P.A., Wooden, J.L., Warner, J.L. and Lee-Berman, R., 1982, Granulite grade supracrustal assemblages of the Quad Creek area, eastern Beartooth Mountains, Montana: Montana Bur. Mines and Geol. Spec. Pub. 84, p.147-156.

Hershey, O.H., 1912, Genesis of silver-lead ores in the Wardner district, Idaho: Mining and Scientific Press, San Francisco, California, 3 parts: June 1, p.750-753, June 8, p.786-790, June 15, p.825-827.

Hershey, O.H., 1916, Origin and distribution of ore in the Coeur d'Alene (pamph.): San Francisco, Mining and Scientific Press, 32p.

Hershey, O.H., 1917, Genesis of Success Zinc-Lead Deposit: Econ. Geol., v.12, p.548-558.

Hietanen, A., 1962, Metasomatic metamorphism in western Clearwater County, Idaho: U.S. Geol. Survey Prof. Paper 344A, 116p.

Hietanen, A., 1967, Scapolite in the Belt Series in the St. Joe-Clearwater region, Idaho: Geol. Soc. America Special Paper 86, 56p.

Hietanen, A., 1984, Geology along the northwest border zone of the Idaho batholith, northern Idaho: U. S. Geological Survey Bulletin 1608, 17p. 
Hobbs, S. Warren, 1971, Sequence of geologic events in the Coeur d'Alene district, Idaho-a new look: Econ. Geol. v.66, no.8, p.1267-1268.

Hobbs, S. W., Griggs, A.B., Wallace, R.E., and Campbell, A.B., 1965, Geology of the Coeur d'Alene district, Shoshone, County, Idaho: U.S. Geological Survey Professional Paper 478, 139p.

James, H.L. and Hedge, C.E., 1980, Age of the basement rocks of southwest Montana: Geol. Soc. America Bull., Part I, V.91, p.11-15.

Kerr, P.F. and Kulp, J.L., 1952, Precambrian uraninite, Sunshine mine, Idaho: Science, v.115, p.86-88.

Kerr, P.F. and Robinson, R.F., 1953, Uranium mineralization in the Sunshine mine, Idaho: Mining Engineering, v.5, p.495-512. (also referenced as: AIME Trans., v.196.).

Kistler, R.W. and Peterman, Z.E., 1973, Variations in Sr, Rb, K, Na, and initial Sr87/Sr86 in Mesozoic granitic rocks and intruded wall rocks in central California: Geol. Soc. America Bull., v.84, p.3489-3512.

Leach, D.L., Landis, G.P., and Hofstra, A.H., 1988, Metamorphic origin of the Coeur d'Alene base- and precious-metal veins in the Belt basin, Idaho and Montana: Geology, v.16, p. 122-125.

Leach, D.L., Hofstra, A.H., Church, S.E., Snee, L.W., Vaughn, R.B., and Zartman, R.E., 1998a, Evidence for Proterozoic and Late Cretaceous-Early Tertiary ore-forming events in the Coeur d'Alene district, Idaho and Montana: Econ Geol., v.93, p.347-359.

Leach, D.L., Hofstra, A.H., Church, S.E., Snee, L.W., Vaughn, R.B., and Zartman, R.E., 1998b, Evidence for Proterozoic and Late Cretaceous-Early Tertiary ore-forming events in the Coeur d'Alene district, Idaho and Montana-a reply: Econ Geol., v.93, p.1106-1109.

Lindgren, W., 1904, A geologic reconnaissance across the Bitterroot Range and Clearwater Mountains in Montana and Idaho: U.S. Geological Survey Professional Paper 27, 123p.

Long, A., Silverman, A.J., and Kulp, J.L., 1960, Isotopic composition of lead and Precambrian mineralization of the Coeur d'Alene district, Idaho: Econ. Geol., v.55, p.645-658. 
McDowell, F.W., 1971, K-Ar ages of igneous rocks from the western United States: Isochron West, no. 2, 16p.

McMechan, M.E. and Price, R.A., 1982, Superimposed low-grade metamorphism in the Mount Fisher area, southeastern British Columbia - implications for the East Kootenay orogeny: Can. Jour. Earth Sci., v.19, p.476-489.

Miller, D.D., 1998, Distributed shear, rotation, and partitioned strain along the San Andreas fault, central California: Geology, v.26, p.867-870.

Mirota, M.D. and Veizer, J, 1994, Geochemistry of Precambrian carbonates: VI. Aphebian Albanel formations, Quebec, Canada: Geochim. Cosmochim. Acta, v.58, p.1735-1745. Mogk, D.A., Mueller, P.A., and Wooden, J.L., 1988, Archean tectonics of the north Snowy block, Beartooth Mountains, Montana: Jour. Geol. v.96, p.125-141.

Mogk, D.A., Mueller, P.A., Wooden, J.L., and Bowes, D.R., 1992, The northern Wyoming Province: Contrasts in Archean crustal evolution: in: Bartholomew, M.J., Hyndman, D.W., Mogk, D.W., and Mason, R., Basement Tectonics 8: Characterization and Comparison of Ancient and Mesozoic Continental Margins - Proceedings of the 8th International Conference on Basement Tectonics (Butte, Montana, 1988), Kluwer Academic Publishers, Dordrecht, The Netherlands, p.283-297.

Mount, V.S. and Suppe, J., 1987, State of stress near the San Andreas fault: Implications for wrench tectonics: Geology, v.15, p.1143-1146.

Mueller, P.A., Shuster, R.D., Graves, M.A., Wooden, J.L., and Bowes, D.R., 1988, Age and composition of a Late Archean magmatic complex, Beartooth Mountains, MontanaWyoming: in Precambrian and Mesozoic Plate Margins: Montana Bur. Min. Geol. Spec. Pub. 96, , p.7-22.

Mueller, P.A., Shuster, R.D., Wooden, J.L., Erslev, E.A., and Bowes, D.R., 1993, Age and composition of Archean crystalline rocks from the southern Madison Range, Montana: Implications for crustal evolution in the Wyoming craton: Geol. Soc. America Bull., v.105, p.437-446. 
Muller, P.A., Shuster, R.D., D'Arcy, K.A., Heatherington, A.L., Nutman, A.P., and Williams, I.S., 1995, Source of the northeast Idaho batholith: Isotopic evidence for a Paleoproterozoic terrane in the northwestern U.S.: Jour. Geol., v.103, p.63-72.

Nabelek, P.I., Labotka, T.C., O'Neil, J.R., and Papike, J.J., 1984, Contrasting fluid/rock interaction between the Notch Peak granitic intrusion and argillites and limestones in western Utah: evidence from stable isotopes and phase assemblages: Contrib. Min. Pet., v.86, p.25-34.

Obradovich, J.D. and Peterman, Z.E., 1968, Geochronology of the Belt Series, Montana: Canadian Jour. Earth Sci., v.5, p.737-747.

Price, R.A., 1981, The Cordilleran foreland thrust and fold belt in the southern Canadian Rocky Mountains: in Price, N.J., and McClay, K.R., eds., Thrust and nappe tectonics: Geol. Soc. London Spec. Pub. 9, p.427-448.

Ramalingaswamy, V.M. and Cheney, E.S., 1982, Stratiform mineralization and origin of some of the vein deposits, Bunker Hill mine, Coeur d'Alene district, Idaho: in Reid, R.R. and Williams, G.A., eds., Society of Economic Geologists' Coeur d'Alene Field Conference, Idaho-1977, Idaho Bur. Mines and Geol. Bull. 24, p. 35-43.

Ransome, F.L. and Calkins, F.C., 1908, The geology and ore deposits of the Coeur d'Alene district, Idaho: U.S. Geological Survey Professional Paper 62, 203p.

Reid, R.R., 1982, Petrography of stratiform lead-zinc-silver deposits at the Bunker Hill mine, Idaho, with some thoughts on the timing of ore deposition: in Reid, R.R. and Williams, G.A., eds., Society of Economic Geologists' Coeur d'Alene Field Conference, Idaho1977, Idaho Bur. Mines and Geol. Bull. 24, p. 45-47.

Reynolds, M.W. and Kleinkopf, M.D., 1977, The Lewis and Clark line, Montana-Idaho: A major intraplate tectonic boundary: Geol. Soc. America Abstracts with Programs, v.9, p.11401141. 
Rosenberg, P.E. and Larson, P.B., 1996, The age of quartz-carbonate veins associated with the Coeur d'Alene mineralization [abs]: Geol. Soc. America Abstracts with Programs, v.28, no.7, p.475.

Schalck, D.K., 1989, The geology and alteration of the Gem Stocks, Shoshone County, Idaho, in V.E. Chamberlain, R.M. Breckenridge, and Bill Bonnichsen, ed., Guidebook to the geology of northern and western Idaho and surrounding area: Idaho Geol. Survey Bull. 28, p.125-135.

Seal, R.R., II and Rye, R.O., 1992, Stable isotope study of water-rock interaction and ore formation, Bayhorse base and precious metal district, Idaho: Econ Geol., v.87, p.271287.

Silverman, A.J., Long, A., and Kulp, J.L., 1960, Isotopic composition of lead and Precambrian mineralization of the Coeur d'Alene district, Idaho: Econ. Geol., v.55, p.645-658.

Snee L.W., Sutter, J.F., and Kelly, W.C., 1988, Thermochronology of economic mineral deposits: Dating the stages of mineralization at Panasqueira, Portugal, by high precision ${ }^{40} \mathrm{Ar} /{ }^{39} \mathrm{Ar}$ age spectrum techniques on muscovite: Econ. Geol., v.83, p.335-354.

Umpleby, J.B., 1924, The Osburn fault, Idaho: Jour. Geol., v.32, no.7, p.601-614.

Umpleby, J.B. and Jones, E.L. Jr., 1923, Geology and ore deposits of Shoshone, County, Idaho: U.S. Geological Survey Bulletin 732, 156p.

Veizer, J., 1989, Strontium isotopes in seawater through time: Ann. Rev. Earth Planet. Sci., v.17, p.141-167.

Veizer, J., Compston, W., Clauer, N. and Schidlowski, M., 1983, ${ }^{87} \mathrm{Sr} /{ }^{86} \mathrm{Sr}$ in Late Proterozoic carbonates: evidence for a mantle event at $\sim 900$ Ma ago: Geochim. Cosmochim. Acta, v.47, p.295-302.

Vulimiri, M.R. and Cheney, E.S., 1981, Stratiform mineralization and origin of some of the vein deposits, Bunker Hill mine, Coeur d'Alene district, Idaho: in Silberman, M. L., Field, C.W., and Berry, A.L., ed., Proceedings of the Symposium on Mineral Deposits of the Pacific Northwest, Geological Society of America, Cordilleran Section Meeting at 
Corvallis, Oregon, March 20-21, 1980: U.S. Geological Survey Open-File Report 81355, p. $248-260$.

Wallace, R.E., Griggs, A.B., Campbell, A.B., and Hobbs, S.W., 1960, Tectonic setting of the Coeur d'Alene district, Idaho: in Short papers in the geological sciences, Geological Survey Research 1960, U.S. Geol. Survey Prof. Paper 400-B, p.25-27.

Walters, W.J., Claypool, G.E., and Choquette, P.W., 1972, Reaction rates and $\delta^{18} \mathrm{O}$ variation for the carbonate-phosphoric acid preparation method: Geochim. Cosmochim. Acta, v.36, p.129-140.

Wavra, C.S., Bond, W.D., and Reid, R.R., 1994, Evidence from the Sunshine mine for dip-slip movement during Coeur d'Alene district mineralization: Econ. Geol., v.89, p.515-527.

Wells, J.D., 1974, Geologic map of the Alberton quadrangle, Missoula, Sanders, and Mineral counties, Montana: U.S. Geological Survey Geologic Quadrangle Map GQ-1157, map scale $1: 62,500$.

White, B.G., 1994, Shear zone hosted ore deposits of the Coeur d'Alene mining district, Idaho, USA: Geol. Soc. America Abstracts With Programs, v.26, no.7, p.21.

White, B.G., 1998a, Diverse tectonism in the Coeur d'Alene mining district, in Berg, R.B., ed., Belt Symposium III: Montana Bur. Mines Geology Spec. Pub. 112, p.254-265.

White, B.G., 1998b, New tricks for an old elephant: revising concepts of Coeur d'Alene geology: Mining Engineering, August, p.27-35.

White, B.G., 2000, Coeur d'Alene mining district: product of preconcentrated source deposits and tectonism within the Lewis and Clark line, in Roberts, S. and Winston, D., eds., Geologic field trips, western Montana and adjacent areas: Geol. Soc. America, p.95-101.

White, B.G. and Applegate, L.M., 2000, Localization of the Coeur d'Alene mining district at the juncture of the Lewis and Clark and Noxon lines: Geol. Soc. America Abstracts with Programs, v.32, no.5, p.42.

White, B.G., Brown, J.L., and Applegate, L.M., 2000a, The Noxon line: A longitudinal arch in the central Belt basin: Geol. Soc. America Abstracts with Programs, v.32, no.5, p.42. 
White, B.G., Winston, D., and Lange, I., 2000b, The Lewis and Clark line and Coeur d'Alene mining district, in Roberts, S. and Winston, D., eds., Geologic field trips, western Montana and adjacent areas: Geol. Soc. America, p.103-121.

Whitehouse, M.J., Stacey, J.S., and Miller, F.K., 1992, Age and nature of the basement in northeastern Washington and northern Idaho: Isotopic evidence from Mesozoic and Cenozoic granitoids: Jour. Geol., v.100, p.691-701.

Wooden, J.L., Mueller, P.A., Mogk, D.A., and Bowes, D.R., 1988, A review of the geochemistry and geochronology of Archean rocks of the Beartooth Mountains, Montana-Wyoming: in Precambrian and Mesozoic Plate Margins: Montana Bur. Min. Geol. Spec. Pub. 96, p.23-42.

Wooden, J.L. and Mueller, P.A., 1988, $\mathrm{Pb}, \mathrm{Sr}$, and $\mathrm{Nd}$ isotopic compositions of a suite of Late Archean, igneous rocks, eastern Beartooth Mountains: implications for crust-mantle evolution: Earth and Planet. Sci. Letters, v.87, p.59-72.

Yates, M.G., 1987, Geology and geochemistry of the Pb-Ag-Cu deposits in the Galena mine, Coeur d'Alene district, Idaho: Ph.D. Thesis, Indiana University,

Zartman, R.E. and Stacey, J.S., 1971, Lead isotopes and mineralization ages in the Belt Supergroup rocks, northwestern Montana and northern Idaho: Econ. Geol., v.66, no.6, p.849-860.

Zartman, R.E. and Smith, 1995, Mineralogy and U-Th-Pb ages of a uranium-bearing jasperoid vein from the Sunshine mine, Coeur d'Alene district, Idaho: Leon T. Silver Symposium, California Institute of Technology, Pasadena, California, April 10-11, p.37-41. 


\section{TABLE CAPTIONS}

TABLE 1. Carbonate mineral samples from mines of the Coeur d'Alene mining district.

TABLE 2. Mean values of $\mathrm{Sr}$ and stable-isotope compositions of vein carbonate in the mines of the Coeur d'Alene mining district.

TABLE 3. Rb and Sr results for rocks of the Belt Supergroup.

TABLE 4. Chemical and isotopic compositions of Sr and possible sources for Coeur d'Alene veins.

TABLE 5. Location and Rb-Sr Data for High-Strontium Plutons of Washington and Idaho. 
TABLE 1. Carbonate Samples From Mines Of The Coeur d'Alene District, Idaho

\begin{tabular}{|c|c|c|c|c|c|c|c|}
\hline Sample \# & Location & $\mathrm{Rb}(\mathrm{ppm})$ & $\mathrm{Sr}(\mathrm{ppm})$ & ${ }^{87} \mathrm{Rb} / 86 \mathrm{Sr}$ & ${ }^{87} \mathrm{Sr} / 86 \mathrm{Sr}$ & $\delta^{18} \mathrm{O}^{*}$ & $\delta^{13} C^{*}$ \\
\hline $\begin{array}{r}\text { Bullion Mine } \\
918-18 \mathrm{E} 1 \\
918-18 \mathrm{E} 2\end{array}$ & Dump, 725m NE of Bullion & $\begin{array}{l}0.586 \\
0.473\end{array}$ & $\begin{array}{r}3.88 \\
34.62\end{array}$ & $\begin{array}{l}0.4387 \\
0.0397\end{array}$ & $\begin{array}{l}0.7580 \\
0.7440\end{array}$ & 17.5 & \\
\hline $\begin{array}{c}\text { Caladay Mine } \\
\text { CAL-1 } \\
\text { CAL-2 } \\
\text { CAL-3 }\end{array}$ & $\begin{array}{c}\text { Underground } \\
\text { " }\end{array}$ & $\begin{array}{l}0.109 \\
0.055 \\
0.090\end{array}$ & $\begin{array}{l}1.92 \\
2.29 \\
2.68\end{array}$ & $\begin{array}{l}0.1669 \\
0.0733 \\
0.1037\end{array}$ & $\begin{array}{l}0.8882 \\
1.3256 \\
1.4122\end{array}$ & & \\
\hline $\begin{array}{c}\text { Carbonate Hill Mine } \\
918-15 \mathrm{Kak} \\
918-15 \mathrm{Ksd}\end{array}$ & Mine dump, east portal & $\begin{array}{l}0.317 \\
0.122\end{array}$ & $\begin{array}{r}60.35 \\
6.43\end{array}$ & $\begin{array}{l}0.0155 \\
0.0565\end{array}$ & $\begin{array}{l}0.9074 \\
1.0152\end{array}$ & $\begin{array}{l}15.6 \\
16.8\end{array}$ & $\begin{array}{l}-7.1 \\
-7.2\end{array}$ \\
\hline $\begin{array}{l}\text { Coeur Mine } \\
\text { COEUR-1 } \\
\text { COEUR-2 }\end{array}$ & Underground & $\begin{array}{l}0.095 \\
0.092\end{array}$ & $\begin{array}{l}4.58 \\
2.97\end{array}$ & $\begin{array}{l}0.0635 \\
0.0929\end{array}$ & $\begin{array}{l}1.2913 \\
1.0865\end{array}$ & & \\
\hline $\begin{array}{r}\text { Galena Mine } \\
918-14 \mathrm{~A} \\
918-14 \mathrm{H}\end{array}$ & $\begin{array}{l}3600 \text { ' level, } 125 \text { vein } \\
4000 \text { ' level, Silver vein }\end{array}$ & $\begin{array}{l}0.117 \\
0.094\end{array}$ & $\begin{array}{r}1.58 \\
12.37\end{array}$ & $\begin{array}{l}0.2232 \\
0.0226\end{array}$ & $\begin{array}{l}1.1358 \\
1.0235\end{array}$ & $\begin{array}{l}16.0 \\
17.7\end{array}$ & $\begin{array}{l}-8.5 \\
-6.9\end{array}$ \\
\hline $\begin{array}{c}\text { Gold Hunter Mine } \\
4050-14-1 \\
4050-15-1 \\
4050-15-2\end{array}$ & $\begin{array}{c}\text { 4050' level, } \\
" \\
"\end{array}$ & $\begin{array}{l}0.071 \\
0.092 \\
0.135\end{array}$ & $\begin{array}{l}17.56 \\
10.52 \\
16.14\end{array}$ & $\begin{array}{l}0.0119 \\
0.0257 \\
0.0247\end{array}$ & $\begin{array}{l}0.8715 \\
0.8540 \\
0.9111\end{array}$ & $\begin{array}{l}17.6 \\
17.2 \\
16.7\end{array}$ & $\begin{array}{l}-7.1 \\
-6.7 \\
-6.3\end{array}$ \\
\hline $\begin{array}{l}\text { Highland Surprise } \\
\qquad 918-17 \mathrm{~F}\end{array}$ & Mine dump, Highland Surprise & 0.079 & 1563. & 0.0001 & 0.8410 & 15.5 & -7.1 \\
\hline $\begin{array}{c}\text { Lucky Friday Mine } \\
918-15 \mathrm{G} \\
918-15 \mathrm{H}\end{array}$ & $\begin{array}{l}5300 \text { ' level, N. Control Flt vein } \\
5300 \text { ' level, } 85 \text { vein }\end{array}$ & $\begin{array}{l}0.062 \\
0.066\end{array}$ & $\begin{array}{r}6.74 \\
87.51\end{array}$ & $\begin{array}{l}0.0271 \\
0.0022\end{array}$ & $\begin{array}{l}0.8570 \\
0.8327\end{array}$ & $\begin{array}{l}13.7 \\
13.7\end{array}$ & $\begin{array}{l}-8.5 \\
-8.1\end{array}$ \\
\hline
\end{tabular}


TABLE 1. Carbonate Samples From Mines Of The Coeur d'Alene District, Idaho (Continued)

\begin{tabular}{|c|c|c|c|c|c|c|c|}
\hline Sample \# & Location & $\mathrm{Rb}(\mathrm{ppm})$ & $\mathrm{Sr}(\mathrm{ppm})$ & ${ }^{87} \mathrm{Rb} /{ }^{86} \mathrm{Sr}$ & ${ }^{87} \mathrm{Sr} /{ }^{86} \mathrm{Sr}$ & $\delta^{18} \mathrm{O}^{*}$ & $\delta^{13} C^{*}$ \\
\hline $\begin{array}{c}\text { Matchless Mine } \\
918-17 \mathrm{C}\end{array}$ & Mine dump, Matchless Mine & 0.092 & 687.0 & 0.0004 & 0.7396 & 13.6 & -9.6 \\
\hline $\begin{array}{l}\text { Sunshine Mine } \\
\text { 42-CH-1 } \\
44-\mathrm{CH}-1 \\
50-\mathrm{CH}-1 \\
50-\mathrm{CH}-3 \\
54-\mathrm{CH}-1 \\
54-\mathrm{CH}-3 \\
56-\mathrm{CH}-1 \\
385-\mathrm{CH}-1\end{array}$ & $\begin{array}{l}\text { Chester Vein } \\
4200 \text { ' level, Chester vein } \\
4400 \text { ' level, Chester vein } \\
5000 \text { ' level, Chester vein } \\
5000 \text { ' level, Chester vein } \\
5400 \text { ' level, Chester vein } \\
5400 \text { ' level, Chester vein } \\
5600 \text { ' level, Chester vein } \\
3850 \text { ' level, Chester vein }\end{array}$ & $\begin{array}{l}0.084 \\
0.062 \\
0.053 \\
0.179 \\
0.070 \\
0.073 \\
0.060 \\
0.096\end{array}$ & $\begin{array}{l}5.37 \\
4.78 \\
4.41 \\
3.78 \\
2.71 \\
3.91\end{array}$ & $\begin{array}{l}0.0431 \\
0.0301 \\
0.1132 \\
0.0490 \\
0.0578 \\
0.0681 \\
0.0742\end{array}$ & $\begin{array}{l}1.2945 \\
1.2461 \\
1.1698 \\
1.3170 \\
1.1417 \\
1.2830 \\
1.1289\end{array}$ & $\begin{array}{l}15.1 \\
16.8 \\
14.4 \\
\\
15.6 \\
\\
14.5 \\
16.0\end{array}$ & $\begin{array}{l}-9.2 \\
-6.7 \\
-8.8 \\
\\
-7.6 \\
-8.8 \\
-7.1\end{array}$ \\
\hline $\begin{array}{l}\text { Sunshine Mine } \\
\text { 44-C28W-A } \\
44-\mathrm{C} 28 \mathrm{~W}-\mathrm{B} \\
44-\mathrm{C} 28 \mathrm{~W}-\mathrm{C} \\
44-\mathrm{C} 28 \mathrm{~W}-\mathrm{D} \\
44-\mathrm{C} 28 \mathrm{~W}-\mathrm{E} \\
44-\mathrm{C} 28 \mathrm{~W}-\mathrm{F} \\
44-\mathrm{C} 28 \mathrm{~W}-\mathrm{G} \\
42-\mathrm{C} 32 \mathrm{~W}-1\end{array}$ & $\begin{array}{c}\text { Copper Vein } \\
\text { Traverse, Copper Vein, } \\
\text { C28W stope, 4400' level } \\
", \\
" \\
" \\
\text { 4200' level, Copper vein }\end{array}$ & $\begin{array}{l}0.078 \\
0.065 \\
0.047 \\
0.037 \\
0.054 \\
0.078 \\
1.138 \\
0.261\end{array}$ & $\begin{array}{r}8.20 \\
20.23 \\
1.37 \\
2.38 \\
2.43 \\
1.61 \\
1.97 \\
7.32\end{array}$ & $\begin{array}{l}0.0277 \\
0.0095 \\
0.1018 \\
0.0457 \\
0.0659 \\
0.1459 \\
1.7445 \\
0.1041\end{array}$ & $\begin{array}{l}0.7921 \\
0.8611 \\
1.0831 \\
0.9661 \\
0.9568 \\
1.0729 \\
1.1550 \\
0.8040\end{array}$ & $\begin{array}{l}17.2 \\
15.6 \\
15.6 \\
15.0 \\
15.2 \\
16.9 \\
17.0\end{array}$ & $\begin{array}{l}-6.8 \\
-9.3 \\
-9.9 \\
-9.9 \\
-9.6 \\
-7.5 \\
-7.2\end{array}$ \\
\hline $\begin{array}{l}\text { Sunshine Mine } \\
\text { 500-1 }\end{array}$ & $\begin{array}{c}\text { Yankee Boy Vein } \\
\text { 500' level, Yankee Boy }\end{array}$ & 0.239 & 8.16 & 0.0865 & 0.9193 & 15.6 & -7.4 \\
\hline $\begin{array}{c}\text { Sunshine Mine } \\
27-Y G-1 \\
27-Y G-5 \\
31-Y G-1 \\
31-Y G-3 \\
37-Y G-1\end{array}$ & $\begin{array}{l}\text { Yankee Girl vein } \\
\text { 2700' level, Yankee Girl vein } \\
\text { " } \\
\text { 3100' level, Yankee Girl vein } \\
\text { 3700' level, Yankee Girl vein }\end{array}$ & $\begin{array}{l}0.106 \\
0.086 \\
0.136 \\
0.099 \\
0.089\end{array}$ & $\begin{array}{l}3.95 \\
2.98 \\
3.09 \\
4.21 \\
1.96\end{array}$ & $\begin{array}{l}0.0825 \\
0.0893 \\
0.1392 \\
0.0745 \\
0.1429\end{array}$ & $\begin{array}{l}1.3149 \\
1.3682 \\
1.6260 \\
1.6408 \\
1.5779\end{array}$ & $\begin{array}{l}15.7 \\
14.1 \\
16.3\end{array}$ & $\begin{array}{l}-7.2 \\
-9.6 \\
-6.9\end{array}$ \\
\hline
\end{tabular}


TABLE 1. Carbonate Samples From Mines Of The Coeur d'Alene District, Idaho (Continued)

\begin{tabular}{|c|c|c|c|c|c|c|c|}
\hline Sample \# & Location & $\mathrm{Rb}(\mathrm{ppm})$ & $\mathrm{Sr}(\mathrm{ppm})$ & ${ }^{87} \mathrm{Rb} /{ }^{86} \mathrm{Sr}$ & ${ }^{87} \mathrm{Sr} / 86 \mathrm{Sr}$ & $\delta^{18 O^{*}}$ & $\delta^{13} C^{*}$ \\
\hline Sunshine Mine & 08 vein & & & & & & \\
\hline P04-08B & $4000^{\prime}$ level, 08 vein & 0.273 & 2.88 & 0.2800 & 0.9190 & & \\
\hline $19-S-1$ & 1900 ' level, 08 vein & 0.351 & 181.4 & 0.0058 & 1.1253 & 13.8 & -7.5 \\
\hline Sunshine Mine & Traverse, D-Vein & & & & & & \\
\hline 40-P74A & P74 stope, 4000 ' level & 1.887 & 2.52 & 2.2447 & 1.0769 & 16.8 & -7.5 \\
\hline 40-P74B & & 0.071 & 1.76 & 0.1212 & 1.1009 & 17.1 & -7.3 \\
\hline $40-\mathrm{P} 74 \mathrm{C}$ & & 0.097 & 1.55 & 0.1859 & 0.9802 & 16.8 & -6.9 \\
\hline 40-P74D & & 0.183 & 1.54 & 0.3521 & 0.9539 & 16.4 & -7.5 \\
\hline $40-\mathrm{P} 74 \mathrm{E}$ & & 0.063 & 1.53 & 0.1231 & 1.0488 & 16.7 & -7.1 \\
\hline 40-P74F & & 0.084 & 1.94 & 0.1293 & 1.0351 & 15.3 & -8.0 \\
\hline $40-\mathrm{P} 74 \mathrm{G}$ & & 0.060 & 1.68 & 0.1082 & 1.2390 & 15.7 & -8.5 \\
\hline $40-\mathrm{P} 74 \mathrm{H}$ & & 0.098 & 1.71 & 0.1696 & 0.9432 & 17.6 & -6.9 \\
\hline $40-\mathrm{P} 74 \mathrm{I}$ & & 0.278 & 2.43 & 0.3447 & 1.1320 & 16.8 & -7.4 \\
\hline $40-\mathrm{P} 74 \mathrm{~J}$ & & 0.079 & 1.38 & 0.1697 & 0.9531 & 17.7 & -6.9 \\
\hline $40-\mathrm{P} 74 \mathrm{~K}$ & & 0.088 & 1.89 & 0.1379 & 0.9465 & 16.7 & -7.6 \\
\hline $40-\mathrm{P} 74 \mathrm{~L}$ & & 0.097 & 4.37 & 0.0660 & 0.9721 & & \\
\hline $40-\mathrm{P} 74 \mathrm{M}$ & & 0.120 & 1.95 & 0.1862 & 1.1548 & & \\
\hline $40-P 74 N$ & & 0.054 & 1.74 & 0.0944 & 1.2325 & & \\
\hline $40-\mathrm{P} 740$ & & 0.056 & 1.83 & 0.0928 & 1.1960 & & \\
\hline 40-P74P & & 0.058 & 1.60 & 0.1094 & 1.1316 & & \\
\hline $40-\mathrm{P} 74 \mathrm{Q}$ & & 0.070 & 1.77 & 0.1182 & 1.1370 & & \\
\hline \multicolumn{8}{|l|}{ Sunshine Mine } \\
\hline 37-R07E-1 & 3700' level, Rambo vein & 0.076 & 5.62 & 0.0397 & 0.9194 & 17.0 & -7.0 \\
\hline $37-\mathrm{R} 05 \mathrm{~W}-1$ & & 0.138 & 2.66 & 0.1537 & 0.9844 & 17.2 & -6.9 \\
\hline \multicolumn{8}{|l|}{ Sunshine Mine } \\
\hline $31-S-1$ & 3100 ' level, Sunshine vein & 0.244 & 11.67 & 0.0618 & 0.9324 & 14.9 & -8.1 \\
\hline $34-S-2$ & 3400' level, Sunshine vein & 0.245 & 5.57 & 0.1299 & 0.9250 & 14.9 & -7.3 \\
\hline
\end{tabular}


TABLE 2. Summary of Results for Mines of the Coeur D'Alene District

\begin{tabular}{lcrrrrr} 
Location & $\mathrm{Rb}(\mathrm{ppm})$ & $\mathrm{Sr}(\mathrm{ppm})$ & ${ }^{87} \mathrm{Rb} / 86 \mathrm{Sr}$ & ${ }^{87} \mathrm{Sr} /{ }^{86} \mathrm{Sr}$ & $\delta^{18} \mathrm{O}^{*}$ & $\delta^{13} \mathrm{C}^{*}$ \\
\hline Bullion Mine & 0.529 & 19.25 & 0.2392 & 0.7510 & 17.5 & -3.7 \\
Caladay Mine & 0.084 & 2.30 & 0.1146 & 1.2087 & & \\
Coeur Mine & 0.093 & 3.78 & 0.0782 & 1.1889 & & \\
Galena Mine & 0.105 & 6.98 & 0.1229 & 1.0797 & 16.8 & -7.7 \\
Carbonate Hill Mine & 0.220 & 33.39 & 0.0360 & 0.9613 & 16.2 & -7.2 \\
Gold Hunter Mine & 0.099 & 14.74 & 0.0207 & 0.8789 & 17.2 & -6.7 \\
Lucky Friday Mine & 0.064 & 47.12 & 0.0147 & 0.8448 & 13.7 & -8.3 \\
Highland Surprise Mine & 0.079 & 1563. & 0.0001 & 0.8410 & 15.5 & -7.1 \\
Matchless Mine & 0.092 & 687. & 0.0004 & 0.7396 & 13.6 & -9.6 \\
Chester vein & 0.085 & 4.42 & 0.0622 & 1.2259 & 15.4 & -8.0 \\
Copper vein & 0.220 & 5.69 & 0.2807 & 0.9614 & 16.1 & -8.6 \\
Yankee Boy vein & 0.239 & 8.16 & 0.0865 & 0.9193 & 15.6 & -7.4 \\
Yankee Girl vein & 0.103 & 3.24 & 0.1057 & 1.5056 & 15.7 & -7.6 \\
08 vein & 0.312 & 92.17 & 0.1429 & 1.0221 & 13.8 & -7.5 \\
D-vein & 0.202 & 1.95 & 0.2796 & 1.0726 & 16.7 & -7.4 \\
Rambo vein & 0.107 & 4.14 & 0.0967 & 0.9519 & 17.1 & -7.0 \\
Sunshine vein & 0.245 & 8.62 & 0.0959 & 0.9287 & 14.9 & -7.7 \\
& & & & & & \\
Mean of All Veins & 0.175 & 86.31 & 0.111 & 1.018 & 15.8 & -7.4 \\
${ }^{*}{ }^{18}$ O and $\delta^{13} \mathrm{C}$ values are reported in permil (\%o). & & & & & &
\end{tabular}


TABLE 3. Rb and Sr Results for Rocks of the Belt Supergroup.

\begin{tabular}{|c|c|c|c|c|c|c|c|c|c|c|}
\hline Sample \# & Latitude & Longitude & Rock Type & Unit & $\mathrm{Rb}$ & $\mathrm{Sr}$ & $\mathrm{Rb} / \mathrm{Sr}$ & ${ }^{87} \mathrm{Rb} /{ }^{86} \mathrm{Sr}$ & ${ }^{87} \mathrm{Sr} /{ }^{86} \mathrm{Sr}$ & Model Age $^{+}$ \\
\hline $858-6 \mathrm{~A}$ & $47^{\circ} 49.63^{\prime}$ & $116^{\circ} 40.57^{\prime}$ & Quartzite & Wallace & 97.3 & 3.7 & 26.114 & 47.1796 & 1.2701 & 838 \\
\hline $6 \mathrm{C}$ & $47^{\circ} 49.53^{\prime}$ & $116^{\circ} 40.46^{\prime}$ & $\mathrm{Bi}-\mathrm{Mu}$ Schist & Wallace & 238.9 & 9.2 & 26.092 & 78.8435 & 1.1613 & 406 \\
\hline $6 \mathrm{D}$ & $47^{\circ} 50.65^{\prime}$ & $116^{\circ} 39.43^{\prime}$ & Argillite & Wallace & 276.8 & 17.0 & 16.271 & 50.2589 & 1.3994 & 966 \\
\hline $6 \mathrm{E}$ & $47^{\circ} 50.75$ & $116^{\circ} 39.33^{\prime}$ & Argillite & Wallace & 176.1 & 10.2 & 17.239 & 53.5341 & 1.4612 & 988 \\
\hline $6 \mathrm{~F}$ & $47^{\circ} 51.46^{\prime}$ & $116^{\circ} 39.16^{\prime}$ & Argillite & Wallace & 154.7 & 5.5 & 28.175 & 87.3447 & 1.4385 & 589 \\
\hline $6 \mathrm{G}$ & $47^{\circ} 48.14^{\prime}$ & $116^{\circ} 37.61^{\prime}$ & Quartzite & Revett & 194.1 & 61.2 & 3.171 & 9.2937 & 0.8410 & 1023 \\
\hline $6 \mathrm{H}$ & $47^{\circ} 47.93^{\prime}$ & $116^{\circ} 36.25^{\prime}$ & Argillite & Wallace & 137.9 & 16.7 & 8.239 & 24.4463 & 0.9584 & 726 \\
\hline $6 I$ & $47^{\circ} 47.58$ & $116^{\circ} 34.80^{\prime}$ & Argillite & Wallace & 117.4 & 45.6 & 2.573 & 7.5234 & 0.8174 & 1044 \\
\hline $6 \mathrm{~J}$ & $47^{\circ} 47.31^{\prime}$ & $116^{\circ} 30.67^{\prime}$ & Siltite & Burke & 171.2 & 74.4 & 2.302 & 6.7472 & 0.8410 & 1405 \\
\hline $6 \mathrm{~K}$ & $47^{\circ} 47.31$ & $116^{\circ} 30.67^{\prime}$ & Siltite & Burke & 146.8 & 42.2 & 3.478 & 10.2455 & 0.8928 & 1279 \\
\hline $6 \mathrm{~L}$ & $47^{\circ} 46.91^{\prime}$ & $116^{\circ} 29.49^{\prime}$ & Calc Argillite & Wallace & 92.3 & 81.2 & 1.136 & 3.3085 & 0.7743 & 1460 \\
\hline $6 \mathrm{M}$ & $47^{\circ} 48.00^{\prime}$ & $116^{\circ} 28.44^{\prime}$ & Shale & Wallace & 151.9 & 14.2 & 10.713 & 32.5280 & 1.2130 & 1091 \\
\hline $6 \mathrm{~N}$ & $47^{\circ} 44.66^{\prime}$ & $116^{\circ} 26.03^{\prime}$ & Quartzite & Wallace & 77.9 & 130.8 & 0.596 & 1.7302 & 0.7477 & 1717 \\
\hline $6 \mathrm{P}$ & $47^{\circ} 44.66^{\prime}$ & $116^{\circ} 26.03^{\prime}$ & Argillite & Wallace & 188.4 & 96.7 & 1.948 & 5.6954 & 0.8125 & 1317 \\
\hline $6 Q$ & $47^{\circ} 44.22^{\prime}$ & $116^{\circ} 21.37^{\prime}$ & Argillite & Wallace & 195.8 & 30.6 & 6.399 & 19.0300 & 0.9927 & 1057 \\
\hline $6 \mathrm{R}$ & $47^{\circ} 44.22^{\prime}$ & $116^{\circ} 21.37^{\prime}$ & Argillite & Wallace & 118.0 & 30.9 & 3.815 & 11.2179 & 0.8745 & 1056 \\
\hline $6 S$ & $47^{\circ} 37.80^{\prime}$ & $116^{\circ} 16.86^{\prime}$ & Quartzite & Wallace & 67.6 & 54.4 & 1.243 & 3.6167 & 0.7695 & 1245 \\
\hline $6 \mathrm{~T}$ & $47^{\circ} 37.80^{\prime}$ & $116^{\circ} 16.86^{\prime}$ & Argillite & Wallace & 210.8 & 39.0 & 5.399 & 15.9306 & 0.9089 & 896 \\
\hline $7 \mathrm{~A}$ & $47^{\circ} 36.54^{\prime}$ & $116^{\circ} 14.05^{\prime}$ & Shale & Wallace & 345.6 & 13.1 & 26.479 & 84.1860 & 1.7179 & 842 \\
\hline $7 \mathrm{~B}$ & $47^{\circ} 36.54^{\prime}$ & $116^{\circ} 14.05^{\prime}$ & Argillite & Wallace & 169.3 & 36.9 & 4.595 & 13.5894 & 0.9348 & 1181 \\
\hline $7 \mathrm{C}$ & $47^{\circ} 38.19^{\prime}$ & $116^{\circ} 11.42^{\prime}$ & Quartzite & Wallace & 69.9 & 62.9 & 1.111 & 3.2341 & 0.7737 & 1480 \\
\hline $7 \mathrm{D}$ & $47^{\circ} 38.19^{\prime}$ & $116^{\circ} 11.42$ & Argillite & Wallace & 151.1 & 32.8 & 4.605 & 13.5747 & 0.9093 & 1052 \\
\hline $7 E$ & $47^{\circ} 41.44^{\prime}$ & $116^{\circ} 09.59^{\prime}$ & Quartzite & Wallace & 71.6 & 94.8 & 0.756 & 2.1969 & 0.7543 & 1563 \\
\hline $7 F$ & $47^{\circ} 41.50^{\prime}$ & $116^{\circ} 09.62^{\prime}$ & Argillite & Wallace & 181.9 & 25.1 & 7.257 & 21.7124 & 1.0564 & 1131 \\
\hline $7 \mathrm{G}$ & $47^{\circ} 39.19^{\prime}$ & $116^{\circ} 01.79^{\prime}$ & Quartzite & Wallace & 23.3 & 125.9 & 0.185 & 0.5365 & 0.7402 & 4475 \\
\hline $7 \mathrm{H}$ & $47^{\circ} 39.19^{\prime}$ & $116^{\circ} 01.79^{\prime}$ & Argillite & Wallace & 220.2 & 32.3 & 6.811 & 20.3270 & 1.2096 & 1727 \\
\hline $7 I$ & $47^{\circ} 47.52^{\prime}$ & $116^{\circ} 04.00^{\prime}$ & Shale & Wallace & 207.9 & 37.0 & 5.621 & 16.7395 & 1.0077 & 1262 \\
\hline $7 \mathrm{~J}$ & $47^{\circ} 47.52^{\prime}$ & $116^{\circ} 04.00^{\prime}$ & Argillite & Wallace & 180.9 & 45.9 & 3.940 & 11.6430 & 0.9272 & 1331 \\
\hline $7 \mathrm{~K}$ & $47^{\circ} 42.05^{\prime}$ & $115^{\circ} 56.54^{\prime}$ & Siltite & St. Regis & 81.0 & 90.4 & 0.896 & 2.6075 & 0.7639 & 1573 \\
\hline $7 \mathrm{~L}$ & $47^{\circ} 41.82^{\prime}$ & $115^{\circ} 57.07$ & Quartzite & Wallace & 32.7 & 455.5 & 0.072 & 0.2079 & 0.7294 & 7816 \\
\hline $7 \mathrm{M}$ & $47^{\circ} 41.82^{\prime}$ & $115^{\circ} 57.07$ & Argillite & Wallace & 207.2 & 22.4 & 9.258 & 28.0368 & 1.1849 & 1195 \\
\hline $7 \mathrm{~N}$ & $47^{\circ} 35.82^{\prime}$ & $115^{\circ} 56.16^{\prime}$ & Argillite & Wallace & 175.3 & 23.2 & 7.567 & 22.5888 & 1.0285 & 1001 \\
\hline
\end{tabular}


TABLE 3. Rb and Sr Results for Rocks of the Belt Supergroup (Continued).

\begin{tabular}{|c|c|c|c|c|c|c|c|c|c|c|}
\hline Sample \# & Latitude & Longitude & Rock Type & Unit & $\mathrm{Rb}$ & $\mathrm{Sr}$ & $\mathrm{Rb} / \mathrm{Sr}$ & ${ }^{87} \mathrm{Rb} /{ }^{86} \mathrm{Sr}$ & ${ }^{87} \mathrm{Sr} /{ }^{86} \mathrm{Sr}$ & Model Age \\
\hline $858-7 \mathrm{P}$ & $47^{\circ} 35.82^{\prime}$ & $115^{\circ} 56.16^{\prime}$ & Quartzite & Wallace & 32.3 & 165.8 & 0.195 & 0.5646 & 0.7269 & 2680 \\
\hline $7 Q$ & $47^{\circ} 33.58^{\prime}$ & $115^{\circ} 55.27^{\prime}$ & Shale & Wallace & 181.8 & 49.8 & 3.652 & 10.7540 & 0.8903 & 1203 \\
\hline $7 \mathrm{R}$ & $47^{\circ} 33.57^{\prime}$ & $115^{\circ} 55.34^{\prime}$ & Argillite & Wallace & 143.3 & 98.3 & 1.457 & 4.2466 & 0.7808 & 1246 \\
\hline $7 \mathrm{~S}$ & $47^{\circ} 24.71^{\prime}$ & $115^{\circ} 53.42^{\prime}$ & Siltite & Wallace & 231.1 & 14.4 & 16.009 & 49.6911 & 1.4549 & 1055 \\
\hline $7 \mathrm{~T}$ & $47^{\circ} 24.40^{\prime}$ & $115^{\circ} 53.11^{\prime}$ & Argillite & Wallace & 184.6 & 28.9 & 6.382 & 18.9888 & 0.9976 & 1077 \\
\hline $7 \mathrm{U}$ & $47^{\circ} 21.38^{\prime}$ & $115^{\circ} 53.24^{\prime}$ & Argillite & Wallace & 163.4 & 31.4 & 5.208 & 15.3773 & 0.9185 & 971 \\
\hline $7 \mathrm{~V}$ & $47^{\circ} 21.38^{\prime}$ & $115^{\circ} 53.24^{\prime}$ & Quartzite & Wallace & 50.8 & 55.1 & 0.921 & 2.6913 & 0.8074 & 2630 \\
\hline $7 \mathrm{~W}$ & $47^{\circ} 19.58^{\prime}$ & $115^{\circ} 55.04^{\prime}$ & Quartzite & Wallace & 75.2 & 21.2 & 3.553 & 10.4422 & 0.8700 & 1104 \\
\hline $7 X$ & $47^{\circ} 19.58^{\prime}$ & $115^{\circ} 55.04^{\prime}$ & Shale & Wallace & 230.6 & 19.5 & 11.802 & 35.4564 & 1.0996 & 779 \\
\hline $8 \mathrm{~A}$ & $47^{\circ} 24.81^{\prime}$ & $115^{\circ} 50.27^{\prime}$ & Quartzite & Wallace & 69.5 & 66.7 & 1.042 & 3.0315 & 0.7759 & 1628 \\
\hline $8 B$ & $47^{\circ} 24.81^{\prime}$ & $115^{\circ} 50.27^{\prime}$ & Argillite & Wallace & 186.6 & 54.0 & 3.457 & 10.1632 & 0.8719 & 1147 \\
\hline $8 \mathrm{C}$ & $47^{\circ} 21.67^{\prime}$ & $115^{\circ} 44.21^{\prime}$ & Quartzite & Wallace & 51.0 & 60.5 & 0.842 & 2.4509 & 0.7704 & 1855 \\
\hline $8 \mathrm{D}$ & $47^{\circ} 21.67^{\prime}$ & $115^{\circ} 44.21^{\prime}$ & Limestone & Wallace & 32.8 & 262.7 & 0.125 & 0.3622 & 0.7378 & 6105 \\
\hline $8 \mathrm{E}$ & $47^{\circ} 19.03^{\prime}$ & $115^{\circ} 45.82^{\prime}$ & Argillite & Wallace & 203.0 & 47.2 & 4.298 & 12.6709 & 0.9018 & 1085 \\
\hline $8 \mathrm{~F}$ & $47^{\circ} 17.14^{\prime}$ & $115^{\circ} 46.26^{\prime}$ & Shale & Wallace & 262.6 & 191.3 & 1.373 & 3.9965 & 0.7731 & 1190 \\
\hline $8 \mathrm{G}$ & $47^{\circ} 16.71^{\prime}$ & $115^{\circ} 46.28^{\prime}$ & Shale & Wallace & 204.1 & 67.4 & 3.028 & 8.8794 & 0.8473 & 1120 \\
\hline $8 \mathrm{H}$ & $47^{\circ} 15.78^{\prime}$ & $115^{\circ} 47.38^{\prime}$ & Slate & Wallace & 89.0 & 120.8 & 0.737 & 2.1441 & 0.7710 & 2135 \\
\hline $8 \mathrm{I}$ & $47^{\circ} 15.15^{\prime}$ & $115^{\circ} 47.76^{\prime}$ & Quartzite & Wallace & 115.0 & 37.2 & 3.089 & 9.0546 & 0.8432 & 1067 \\
\hline $8 \mathrm{~L}$ & $47^{\circ} 10.59^{\prime}$ & $115^{\circ} 29.93^{\prime}$ & Calc Argillite & Wallace & 134.5 & 48.2 & 2.791 & 8.2054 & 0.8735 & 1432 \\
\hline $8 \mathrm{M}$ & $47^{\circ} 10.10^{\prime}$ & $115^{\circ} 30.34^{\prime}$ & Quartzite & Wallace & 12.5 & 32.4 & 0.387 & 1.1270 & 0.7627 & 3516 \\
\hline $8 \mathrm{~N}$ & $47^{\circ} 09.78^{\prime}$ & $115^{\circ} 31.58^{\prime}$ & Quartzite & Wallace & 119.5 & 85.7 & 1.394 & 4.0696 & 0.7994 & 1615 \\
\hline $8 \mathrm{P}$ & $47^{\circ} 09.11^{\prime}$ & $115^{\circ} 32.12^{\prime}$ & Quartzite & Wallace & 33.8 & 45.9 & 0.735 & 2.1378 & 0.7576 & 1712 \\
\hline $8 Q$ & $47^{\circ} 08.81^{\prime}$ & $115^{\circ} 33.28^{\prime}$ & Argillite & Wallace & 127.4 & 96.4 & 1.322 & 3.8532 & 0.7854 & 1454 \\
\hline $8 \mathrm{R}$ & $47^{\circ} 07.55^{\prime}$ & $115^{\circ} 35.28^{\prime}$ & Quartzite & Wallace & 69.0 & 36.3 & 1.902 & 5.5554 & 0.8053 & 1260 \\
\hline $8 S$ & $47^{\circ} 09.46^{\prime}$ & $115^{\circ} 38.19^{\prime}$ & Shale & Wallace & 183.3 & 50.6 & 3.619 & 10.6546 & 0.8928 & 1230 \\
\hline $8 \mathrm{~T}$ & $47^{\circ} 09.46^{\prime}$ & $115^{\circ} 38.19^{\prime}$ & Quartzite & Wallace & 111.1 & 58.4 & 1.902 & 5.5492 & 0.7945 & 1127 \\
\hline $8 \mathrm{U}$ & $47^{\circ} 10.15^{\prime}$ & $115^{\circ} 39.23^{\prime}$ & Quartzite & Wallace & 96.7 & 77.4 & 1.248 & 3.6446 & 0.8013 & 1837 \\
\hline $8 \mathrm{~V}$ & $47^{\circ} 10.15^{\prime}$ & $115^{\circ} 39.23^{\prime}$ & Argillite & Wallace & 154.3 & 102.1 & 1.511 & 4.4099 & 0.7944 & 1413 \\
\hline $8 W$ & $47^{\circ} 11.91^{\prime}$ & $115^{\circ} 30.52^{\prime}$ & Quartzite & Wallace & 12.6 & 2.1 & 5.983 & 17.4941 & 0.8169 & 449 \\
\hline $8 X$ & $47^{\circ} 11.95^{\prime}$ & $115^{\circ} 30.58^{\prime}$ & Argillite & Wallace & 204.2 & 33.5 & 6.100 & 17.8882 & 0.8455 & 551 \\
\hline $8 Y$ & $47^{\circ} 13.51^{\prime}$ & $115^{\circ} 34.92^{\prime}$ & Quartzite & Wallace & 38.5 & 28.4 & 1.355 & 3.9477 & 0.7774 & 1280 \\
\hline $8 Z$ & $47^{\circ} 13.51^{\prime}$ & $115^{\circ} 34.92^{\prime}$ & Shale & Wallace & 172.8 & 50.0 & 3.456 & 10.1696 & 0.8750 & 1167 \\
\hline
\end{tabular}


TABLE 3. Rb and Sr Results for Rocks of the Belt Supergroup (Continued).

\begin{tabular}{|c|c|c|c|c|c|c|c|c|c|c|}
\hline Sample \# & Latitude & Longitude & Rock Type & Unit & $\mathrm{Rb}$ & $\mathrm{Sr}$ & $\mathrm{Rb} / \mathrm{Sr}$ & ${ }^{87} \mathrm{Rb} /{ }^{86} \mathrm{Sr}$ & ${ }^{87} \mathrm{Sr} /{ }^{86} \mathrm{Sr}$ & Model Ag \\
\hline $858-8 \mathrm{AA}$ & $47^{\circ} 14.56^{\prime}$ & $115^{\circ} 38.58^{\prime}$ & Quartzite & Wallace & 45.6 & 57.7 & 0.791 & 2.3099 & 0.8065 & 3028 \\
\hline $8 \mathrm{AB}$ & $47^{\circ} 14.56^{\prime}$ & $115^{\circ} 38.58^{\prime}$ & Argillite & Wallace & 237.3 & 19.3 & 12.285 & 36.6022 & 1.0120 & 588 \\
\hline $8 \mathrm{AD}$ & $47^{\circ} 13.72^{\prime}$ & $115^{\circ} 42.45^{\prime}$ & Argillite & Wallace & 197.7 & 36.4 & 5.435 & 16.1570 & 0.9878 & 1222 \\
\hline $9 \mathrm{~A}$ & $47^{\circ} 30.34^{\prime}$ & $116^{\circ} 04.28^{\prime}$ & Quartzite & Revett & 281.8 & 8.8 & 32.110 & 104.0420 & 1.9335 & 827 \\
\hline $9 \mathrm{~B}$ & $47^{\circ} 30.28^{\prime}$ & $116^{\circ} 04.63^{\prime}$ & Quartzite & Revett & 113.8 & 5.9 & 19.452 & 61.3530 & 1.6319 & 1056 \\
\hline $9 \mathrm{C}$ & $47^{\circ} 30.13^{\prime}$ & $116^{\circ} 04.23^{\prime}$ & Argillite & St. Regis & 253.1 & 8.6 & 29.519 & 92.1990 & 1.5202 & 620 \\
\hline $9 \mathrm{D}$ & $47^{\circ} 27.32^{\prime}$ & $116^{\circ} 04.40^{\prime}$ & Quartzite & Wallace & 75.6 & 43.8 & 1.728 & 5.0514 & 0.8130 & 1490 \\
\hline $9 \mathrm{E}$ & $47^{\circ} 27.32^{\prime}$ & $116^{\circ} 04.40^{\prime}$ & Argillite & Wallace & 324.6 & 20.0 & 16.220 & 49.3552 & 1.2363 & 754 \\
\hline $9 \mathrm{~F}$ & $47^{\circ} 16.37^{\prime}$ & $115^{\circ} 07.92^{\prime}$ & Slate & Wallace & 85.5 & 208.0 & 0.411 & 1.1934 & 0.7473 & 2453 \\
\hline $9 \mathrm{G}$ & $47^{\circ} 16.37^{\prime}$ & $115^{\circ} 07.92^{\prime}$ & Slate & Wallace & 7.0 & 23.4 & 0.300 & 18.5089 & 0.8850 & 682 \\
\hline $9 \mathrm{H}$ & $47^{\circ} 14.35^{\prime}$ & $115^{\circ} 13.36^{\prime}$ & Slate & Wallace & 184.8 & 49.4 & 3.743 & 10.9526 & 0.8228 & 753 \\
\hline $9 I$ & $47^{\circ} 14.29^{\prime}$ & $115^{\circ} 13.32$ & Siltite & Wallace & 126.8 & 87.5 & 1.449 & 4.2176 & 0.7697 & 1072 \\
\hline $9 \mathrm{~J}$ & $47^{\circ} 13.57^{\prime}$ & $115^{\circ} 18.01^{\prime}$ & Slate & Wallace & 181.2 & 37.0 & 4.894 & 14.3596 & 0.8524 & 719 \\
\hline $9 \mathrm{~K}$ & $47^{\circ} 13.57^{\prime}$ & $115^{\circ} 18.01^{\prime}$ & Quartzite & Wallace & 85.0 & 212.9 & 0.400 & 1.1608 & 0.7503 & 2696 \\
\hline $9 \mathrm{~L}$ & $47^{\circ} 13.47^{\prime}$ & $115^{\circ} 21.20^{\prime}$ & Argillite & Wallace & 239.8 & 25.1 & 9.563 & 28.0847 & 0.8631 & 395 \\
\hline $9 \mathrm{M}$ & $47^{\circ} 13.47^{\prime}$ & $115^{\circ} 21.20^{\prime}$ & Quartzite & Wallace & 70.7 & 39.3 & 1.800 & 5.2627 & 0.8156 & 1465 \\
\hline 9P & $47^{\circ} 05.73^{\prime}$ & $115^{\circ} 22.67^{\prime}$ & Quartzite & Wallace & 178.1 & 51.6 & 3.454 & 10.1186 & 0.8331 & 886 \\
\hline $9 Q$ & $47^{\circ} 05.73^{\prime}$ & $115^{\circ} 22.67^{\prime}$ & Quartzite & Wallace & 61.7 & 34.7 & 1.780 & 5.2171 & 0.8400 & 1799 \\
\hline $9 \mathrm{R}$ & $47^{\circ} 09.50^{\prime}$ & $115^{\circ} 23.67^{\prime}$ & Quartzite & Wallace & 137.8 & 89.8 & 1.533 & 4.4883 & 0.8270 & 1889 \\
\hline $9 \mathrm{~S}$ & $47^{\circ} 09.50^{\prime}$ & $115^{\circ} 23.67^{\prime}$ & Quartzite & Wallace & 42.4 & 12.9 & 3.285 & 9.6034 & 0.8137 & 793 \\
\hline $10 \mathrm{~B}$ & $46^{\circ} 29.26^{\prime}$ & $115^{\circ} 42.46^{\prime}$ & Bi-Mu Schist & Wallace & 252.1 & 45.7 & 5.517 & 15.9980 & 0.7303 & 111 \\
\hline $10 \mathrm{D}$ & $46^{\circ} 31.46^{\prime}$ & $115^{\circ} 39.63^{\prime}$ & Bi-Mu Schist & Wallace & 114.9 & 72.9 & 1.577 & 4.5794 & 0.7482 & 661 \\
\hline $10 \mathrm{H}$ & $46^{\circ} 29.18^{\prime}$ & $115^{\circ} 40.23^{\prime}$ & Bi-Mu Schist & Wallace & 120.1 & 23.1 & 5.191 & 14.7100 & 0.7302 & 121 \\
\hline $11 \mathrm{~A}$ & $46^{\circ} 37.20^{\prime}$ & $115^{\circ} 47.71^{\prime}$ & Bi-Mu Schist & Wallace & 277.0 & 97.0 & 2.857 & 8.3125 & 0.7810 & 641 \\
\hline $11 \mathrm{~B}$ & $46^{\circ} 37.20^{\prime}$ & $115^{\circ} 47.71$ & Bi-Mu Schist & Wallace & 194.2 & 90.3 & 2.151 & 6.2560 & 0.7635 & 655 \\
\hline $11 \mathrm{C}$ & $46^{\circ} 35.18^{\prime}$ & $115^{\circ} 50.02^{\prime}$ & Bi Schist & Wallace & 112.4 & 192.7 & 0.583 & 1.6924 & 0.7334 & 1172 \\
\hline $918-12 \mathrm{~A}$ & $47^{\circ} 25.62^{\prime}$ & $116^{\circ} 12.83^{\prime}$ & Quartzite & Revett & 95.1 & 9.52 & 9.989 & 30.4477 & 1.2543 & 1259 \\
\hline $12 B$ & $47^{\circ} 25.17^{\prime}$ & $116^{\circ} 12.30^{\prime}$ & Argillite & St. Regis & 249 & 27.5 & 9.055 & 27.3842 & 1.1709 & 1188 \\
\hline $12 \mathrm{C}$ & $47^{\circ} 24.95^{\prime}$ & $116^{\circ} 11.20^{\prime}$ & Siltite & Wallace & 136 & 62.4 & 2.179 & 6.3871 & 0.8395 & 1467 \\
\hline $12 \mathrm{D}$ & $47^{\circ} 24.95^{\prime}$ & $116^{\circ} 11.20^{\prime}$ & Quartzite & Wallace & 50.6 & 38.0 & 1.332 & 3.8846 & 0.7926 & 1570 \\
\hline $12 \mathrm{E}$ & $47^{\circ} 24.85^{\prime}$ & $116^{\circ} 12.43^{\prime}$ & Argillite & St. Regis & 212 & 12.6 & 16.825 & 52.7259 & 1.5573 & 1129 \\
\hline $12 \mathrm{~F}$ & $47^{\circ} 24.41$ & $116^{\circ} 12.66^{\prime}$ & Siltite & St. Regis & 148 & 31.5 & 4.698 & 13.9125 & 0.9474 & 1216 \\
\hline
\end{tabular}


TABLE 3. Rb and Sr Results for Rocks of the Belt Supergroup (Continued).

\begin{tabular}{|c|c|c|c|c|c|c|c|c|c|c|}
\hline Sample \# & Latitude & Longitude & Rock Type & Unit & $\mathrm{Rb}$ & $\mathrm{Sr}$ & $\mathrm{Rb} / \mathrm{Sr}$ & ${ }^{87} \mathrm{Rb} /{ }^{86} \mathrm{Sr}$ & ${ }^{87} \mathrm{Sr} /^{86} \mathrm{Sr}$ & Model Age \\
\hline $918-12 \mathrm{G}$ & $47^{\circ} 24.41^{\prime}$ & $116^{\circ} 12.66^{\prime}$ & Quartzite & St. Regis & 141 & 28.6 & 4.930 & 14.6230 & 0.9650 & 1241 \\
\hline $12 \mathrm{H}$ & $47^{\circ} 25.04^{\prime}$ & $116^{\circ} 16.06^{\prime}$ & Quartzite & Revett & 120 & 9.08 & 13.216 & 40.4972 & 1.3120 & 1048 \\
\hline $12 \mathrm{I}$ & $47^{\circ} 30.13^{\prime}$ & $116^{\circ} 04.23^{\prime}$ & Argillite & St. Regis & 186 & 8.19 & 22.711 & 69.6763 & 1.3251 & 624 \\
\hline $13 \mathrm{~A}$ & $47^{\circ} 28.72^{\prime}$ & $115^{\circ} 57.96^{\prime}$ & Argillite & St. Regis & 357 & 3.20 & 111.423 & 368.2909 & 2.1636 & 278 \\
\hline $13 B$ & $47^{\circ} 28.72^{\prime}$ & $115^{\circ} 57.96^{\prime}$ & Quartzite & St. Regis & 126 & 31.9 & 3.950 & 11.8468 & 1.0824 & 2209 \\
\hline $13 \mathrm{C}$ & $47^{\circ} 29.08^{\prime}$ & $115^{\circ} 57.70^{\prime}$ & Limestone & Wallace & 17.6 & 318.5 & 0.055 & 0.1608 & 0.7681 & 23312 \\
\hline $13 \mathrm{D}$ & $47^{\circ} 29.08^{\prime}$ & $115^{\circ} 57.70^{\prime}$ & Shale & Wallace & 154 & 30.41 & 5.064 & 14.9453 & 0.9118 & 968 \\
\hline $13 \mathrm{E}$ & $47^{\circ} 29.08^{\prime}$ & $115^{\circ} 57.70^{\prime}$ & Quartzite & Wallace & 44.5 & 63.9 & 0.696 & 2.0291 & 0.7798 & 2549 \\
\hline $13 \mathrm{~F}$ & $47^{\circ} 32.00^{\prime}$ & $116^{\circ} 03.34^{\prime}$ & Siltite & Prichard & 170 & 81.4 & 2.088 & 6.1125 & 0.8262 & 1383 \\
\hline $13 \mathrm{G}$ & $47^{\circ} 30.37^{\prime}$ & $115^{\circ} 52.41^{\prime}$ & Monzonite & Gem Stock & 221 & 1244.5 & 0.178 & 0.5137 & 0.7056 & 79 \\
\hline $13 \mathrm{H}$ & $47^{\circ} 30.39^{\prime}$ & $115^{\circ} 52.37^{\prime}$ & Monzonite & Gem Stock & 130 & 1384.9 & 0.094 & 0.2715 & 0.7055 & 123 \\
\hline $13 \mathrm{I}$ & $47^{\circ} 30.10^{\prime}$ & $115^{\circ} 52.83^{\prime}$ & Siltite & Prichard & 225 & 40.8 & 5.515 & 16.2681 & 0.9080 & 873 \\
\hline $13 \mathrm{~J}$ & $47^{\circ} 31.95^{\prime}$ & $115^{\circ} 52.06^{\prime}$ & Monzonite & Gem Stock & 143 & 1500 & 0.095 & 0.2758 & 0.7059 & 225 \\
\hline $13 \mathrm{~K}$ & $47^{\circ} 32.28^{\prime}$ & $115^{\circ} 51.68^{\prime}$ & Granite & Pegmatite & 707 & 36.53 & 19.354 & 56.5686 & 0.8122 & 133 \\
\hline $13 \mathrm{M}$ & $47^{\circ} 32.14^{\prime}$ & $115^{\circ} 52.85^{\prime}$ & Argillite & Prichard & 194 & 44.8 & 4.330 & 12.7238 & 0.8668 & 890 \\
\hline $14 B$ & $47^{\circ} 28.41^{\prime}$ & $115^{\circ} 57.51^{\prime}$ & Quartzite & Revett & 82.6 & 5.74 & 14.390 & 44.3710 & 1.3795 & 1063 \\
\hline $14 \mathrm{D}$ & $47^{\circ} 28.42^{\prime}$ & $115^{\circ} 57.59^{\prime}$ & Quartzite & Revett & 70.8 & 6.63 & 10.679 & 32.6102 & 1.2748 & 1220 \\
\hline $14 K$ & $47^{\circ} 28.55^{\prime}$ & $115^{\circ} 57.90^{\prime}$ & Quartzite & Revett & 114 & 6.85 & 16.642 & 52.1016 & 1.5465 & 1128 \\
\hline $14 \mathrm{~L}$ & $47^{\circ} 38.06^{\prime}$ & $115^{\circ} 58.72^{\prime}$ & Quartzite & Revett & 67.7 & 6.41 & 10.562 & 32.2493 & 1.2737 & 1231 \\
\hline $14 \mathrm{M}$ & $47^{\circ} 35.65^{\prime}$ & $115^{\circ} 47.83^{\prime}$ & Siltite & Prichard & 209 & 65.8 & 3.176 & 9.3181 & 0.8504 & 1090 \\
\hline $14 \mathrm{~N}$ & $47^{\circ} 36.05^{\prime}$ & $115^{\circ} 47.72^{\prime}$ & Siltite & Prichard & 172 & 71.1 & 2.419 & 7.0780 & 0.8228 & 1163 \\
\hline $14 \mathrm{P}$ & $47^{\circ} 37.52^{\prime}$ & $115^{\circ} 51.09^{\prime}$ & Siltite & Prichard & 191 & 47.3 & 4.038 & 11.8760 & 0.8765 & 1009 \\
\hline $14 Q$ & $47^{\circ} 41.29^{\prime}$ & $115^{\circ} 46.35^{\prime}$ & Siltite & Prichard & 174 & 86.2 & 2.019 & 5.9049 & 0.8210 & 1370 \\
\hline $15 \mathrm{D}$ & $47^{\circ} 28.17^{\prime}$ & $115^{\circ} 46.84^{\prime}$ & Quartzite & Revett & 46.2 & 26.7 & 1.730 & 5.2730 & 1.2522 & 6953 \\
\hline $15 \mathrm{~J}$ & $47^{\circ} 28.08^{\prime}$ & $115^{\circ} 45.83^{\prime}$ & Shale & Wallace & 194 & 26.7 & 7.266 & 21.5890 & 0.9833 & 902 \\
\hline $15 \mathrm{~L}$ & $47^{\circ} 27.06^{\prime}$ & $115^{\circ} 46.08^{\prime}$ & Shale & St. Regis & 194 & 13.5 & 14.370 & 43.7870 & 1.2510 & 873 \\
\hline $15 \mathrm{M}$ & $47^{\circ} 27.06^{\prime}$ & $115^{\circ} 46.08^{\prime}$ & Quartzite & St. Regis & 49.1 & 27.3 & 1.799 & 5.3741 & 1.0426 & 4291 \\
\hline $16 \mathrm{~A}$ & $47^{\circ} 29.60^{\prime}$ & $115^{\circ} 58.35^{\prime}$ & Argillite & Wallace & 233 & 22.2 & 10.495 & 31.3957 & 1.0543 & 779 \\
\hline $16 \mathrm{~B}$ & $47^{\circ} 23.29^{\prime}$ & $115^{\circ} 48.66^{\prime}$ & Argillite & Wallace & 298 & 13.3 & 22.406 & 70.6887 & 1.6321 & 918 \\
\hline $16 \mathrm{C}$ & $47^{\circ} 20.49^{\prime}$ & $115^{\circ} 37.48^{\prime}$ & Argillite & Wallace & 232 & 13.1 & 17.710 & 53.2287 & 1.1046 & 527 \\
\hline $16 \mathrm{D}$ & $47^{\circ} 20.79^{\prime}$ & $115^{\circ} 44.22^{\prime}$ & Siltite & Wallace & 151 & 43.3 & 3.487 & 10.2719 & 0.8923 & 1273 \\
\hline $16 \mathrm{E}$ & $47^{\circ} 18.67^{\prime}$ & $115^{\circ} 45.95^{\prime}$ & Phyllite & Wallace & 197 & 58.8 & 3.350 & 9.8360 & 0.8581 & 1088 \\
\hline
\end{tabular}


TABLE 3. Rb and Sr Results for Rocks of the Belt Supergroup (Continued).

\begin{tabular}{|c|c|c|c|c|c|c|c|c|c|c|}
\hline Sample \# & Latitude & Longitude & Rock Type & Unit & $\mathrm{Rb}$ & $\mathrm{Sr}$ & $\mathrm{Rb} / \mathrm{Sr}$ & ${ }^{87} \mathrm{Rb} /{ }^{86} \mathrm{Sr}$ & ${ }^{87} \mathrm{Sr} /{ }^{86} \mathrm{Sr}$ & Model Age \\
\hline $918-16 \mathrm{~F}$ & $47^{\circ} 15.12^{\prime}$ & $115^{\circ} 50.69^{\prime}$ & Argillite & Wallace & 178 & 48.8 & 3.646 & 10.7071 & 0.8618 & 1024 \\
\hline $16 \mathrm{G}$ & $47^{\circ} 15.37^{\prime}$ & $115^{\circ} 55.33^{\prime}$ & Argillite & Wallace & 178 & 69.2 & 2.572 & 7.5273 & 0.8246 & 1110 \\
\hline $16 \mathrm{H}$ & $47^{\circ} 18.39^{\prime}$ & $115^{\circ} 55.51^{\prime}$ & Slate & Wallace & 470 & 12.4 & 37.903 & 116.4794 & 1.3430 & 385 \\
\hline $16 I$ & $47^{\circ} 17.20^{\prime}$ & $115^{\circ} 55.95^{\prime}$ & Argillite & Wallace & 173 & 13.7 & 12.628 & 37.4142 & 0.9536 & 466 \\
\hline $16 \mathrm{~J}$ & $47^{\circ} 16.23^{\prime}$ & $115^{\circ} 55.93^{\prime}$ & Argillite & Wallace & 195 & 14 & 13.929 & 41.6782 & 1.0576 & 593 \\
\hline $16 \mathrm{~K}$ & $47^{\circ} 16.02^{\prime}$ & $116^{\circ} 04.61^{\prime}$ & Granite & Pluton & 86.8 & 409 & 0.212 & 0.6145 & 0.7161 & 1259 \\
\hline $16 \mathrm{M}$ & $47^{\circ} 17.63^{\prime}$ & $116^{\circ} 07.42^{\prime}$ & Argillite & Wallace & 124 & 57.1 & 2.172 & 6.3876 & 0.8778 & 1880 \\
\hline $17 \mathrm{~A}$ & $47^{\circ} 31.19^{\prime}$ & $116^{\circ} 14.45^{\prime}$ & Siltite & Prichard & 156 & 56.0 & 2.786 & 8.1582 & 0.8325 & 1092 \\
\hline $17 \mathrm{~B}$ & $47^{\circ} 30.67^{\prime}$ & $116^{\circ} 14.48^{\prime}$ & Shale & Prichard & 253 & 35.9 & 7.047 & 20.8578 & 0.9423 & 797 \\
\hline $17 \mathrm{D}$ & $47^{\circ} 28.82^{\prime}$ & $116^{\circ} 14.80^{\prime}$ & Argillite & Prichard & 192 & 70 & 2.743 & 8.0397 & 0.8416 & 1186 \\
\hline $17 \mathrm{E}$ & $47^{\circ} 28.84^{\prime}$ & $116^{\circ} 09.75^{\prime}$ & Argillite & Prichard & 197 & 49.9 & 3.948 & 11.5995 & 0.8663 & 972 \\
\hline $17 \mathrm{H}$ & $47^{\circ} 27.20^{\prime}$ & $116^{\circ} 10.89^{\prime}$ & Argillite & Prichard & 231 & 60.5 & 3.818 & 11.2658 & 0.9102 & 1271 \\
\hline $17 \mathrm{I}$ & $47^{\circ} 22.02^{\prime}$ & $116^{\circ} 10.98^{\prime}$ & Argillite & Striped Peak & 252 & 29.2 & 8.630 & 25.8217 & 1.0567 & 953 \\
\hline $17 \mathrm{~J}$ & $47^{\circ} 20.46^{\prime}$ & $116^{\circ} 09.73^{\prime}$ & Argillite & Striped Peak & 260 & 14.2 & 18.310 & 56.7856 & 1.4430 & 909 \\
\hline $17 \mathrm{~K}$ & $47^{\circ} 19.04^{\prime}$ & $116^{\circ} 09.17^{\prime}$ & Argillite & Wallace & 213 & 16.74 & 12.723 & 37.8705 & 1.0017 & 550 \\
\hline $17 \mathrm{~L}$ & $47^{\circ} 20.66^{\prime}$ & $116^{\circ} 37.01^{\prime}$ & Siltite & Wallace & 126 & 31.1 & 4.051 & 11.8242 & 0.7970 & 546 \\
\hline $17 \mathrm{M}$ & $47^{\circ} 25.62^{\prime}$ & $116^{\circ} 37.51^{\prime}$ & Argillite & Wallace & 236 & 139 & 1.698 & 4.9552 & 0.7970 & 1295 \\
\hline $17 N$ & $47^{\circ} 32.12^{\prime}$ & $116^{\circ} 30.64^{\prime}$ & Siltite & Burke & 150 & 69.85 & 2.148 & 6.2757 & 0.8099 & 1167 \\
\hline $18 \mathrm{~A}$ & $47^{\circ} 28.05^{\prime}$ & $115^{\circ} 50.68^{\prime}$ & Argillite & St. Regis & 214 & 27.70 & 7.726 & 23.1272 & 1.0610 & 1076 \\
\hline $18 \mathrm{~B}$ & $47^{\circ} 27.59^{\prime}$ & $115^{\circ} 43.39^{\prime}$ & Phyllite & St. Regis & 158 & 33.73 & 4.684 & 13.7546 & 0.8603 & 791 \\
\hline $18 \mathrm{C}$ & $47^{\circ} 24.39^{\prime}$ & $115^{\circ} 41.73^{\prime}$ & Argillite & Wallace & 163 & 31.7 & 5.142 & 15.2249 & 0.9467 & 1109 \\
\hline $18 \mathrm{D}$ & $47^{\circ} 24.39^{\prime}$ & $115^{\circ} 41.73^{\prime}$ & Argillite & Wallace & 250 & 12.71 & 19.676 & 60.1141 & 1.2800 & 670 \\
\hline
\end{tabular}

+ Model ages are reported in $\mathrm{Ma}$ and assume an initial ${ }^{87} \mathrm{Sr} /{ }^{86} \mathrm{Sr}$ ratio of Mesoproterozoic seawater of 0.705 (Mirota and Veizer, 1994). 
TABLE 4. Compositions of Possible Sources of Coeur d'Alene Veins

$\mathrm{Rb}(\mathrm{ppm}) \quad \mathrm{Sr}(\mathrm{ppm}) \quad{ }^{87} \mathrm{Rb} /{ }^{86} \mathrm{Sr} \quad{ }^{87} \mathrm{Sr} / 86 \mathrm{Sr}$

Belt Supergroup, Metasedimentary Rocks 1

$\begin{array}{lllll}\text { Average } & 160 & 60 & 15.27 & 0.925 \\ \text { Median } & 158 & 47 & 9.64 & 0.862 \\ \text { Supergroup, Carbonate Rocks }{ }^{2} & 11 & 95 & 0.34 & 0.714 \\ \text { Average } & & & & \\ \text { Median } & 19 & 178 & 0.392 & 0.719 \\ & 8 & 127 & 0.305 & 0.717\end{array}$

Archean Granitoid Rocks 4

$\begin{array}{lllll}\text { Average } & 75 & 294 & 1.321 & 0.760 \\ \text { Median } & 62 & 260 & 0.768 & 0.740\end{array}$

1 Obradovich and Peterman (1968), Criss and Fleck (1987), and Fleck, R.J. (unpublished measurements)

2 Obradovich and Peterman (1968) and Fleck (unpublished measurements)

3 Mogk and others, 1988, 1992, and Wooden and Mueller, 1988

4 Henry and others, 1982, and Wooden and Mueller, 1988, Mogk and others, 1992, Mueller and others, 1993. 
TABLE 5. Location and Rb-Sr Data for High-Strontium Plutons of Washington and Idaho

\begin{tabular}{ccccccccr} 
Sample \# & Latitude & Longitude & $\mathrm{Rb}(\mathrm{ppm}) \mathrm{Sr}(\mathrm{ppm}){ }^{87} \mathrm{Rb} /{ }^{86} \mathrm{Sr}$ & ${ }^{87} \mathrm{Sr} /{ }^{86} \mathrm{Sr}$ & Age $(\mathrm{Ma})$ & Sri \\
\hline Gem Stocks & & & & & & & & \\
\\
$918-13 \mathrm{G}$ & $47^{\circ} 30^{\prime} 21.9^{\prime \prime} \mathrm{N}$ & $115^{\circ} 52^{\prime} 24.6^{\prime \prime} \mathrm{W}$ & 221 & 1245 & 0.3995 & 0.70558 & 110 & 0.7050 \\
$918-13 \mathrm{H}$ & $47^{\circ} 30^{\prime} 23.3^{\prime \prime} \mathrm{N}$ & $115^{\circ} 52^{\prime} 22.5^{\prime \prime} \mathrm{W}$ & 130 & 1385 & 0.2293 & 0.70548 & 110 & 0.7051 \\
$918-13 \mathrm{~J}$ & $47^{\circ} 31^{\prime} 57.2^{\prime \prime} \mathrm{N}$ & $115^{\circ} 52^{\prime} 04.0^{\prime \prime} \mathrm{W}$ & 143 & 1500 & 0.2758 & 0.70588 & 110 & 0.7054
\end{tabular}

Silver Point Granite and Other Plutons of Northern Washington and Idaho

$\begin{array}{lllllllll}837-8 \mathrm{~A} & 48^{\circ} 15^{\prime} 10.8^{\prime \prime} \mathrm{N} & 116^{\circ} 36^{\prime} 35.4^{\prime \prime} \mathrm{W} & 75.3 & 1078 & 0.2020 & 0.70539 & 50 & 0.7052 \\ 837-8 \mathrm{C} & 48^{\circ} 15^{\prime} 38.0^{\prime \prime} \mathrm{N} & 116^{\circ} 19^{\prime} 44.4^{\prime \prime} \mathrm{W} & 78.4 & 1254 & 0.1809 & 0.70569 & 52 & 0.7056 \\ 837-10 \mathrm{~A} & 48^{\circ} 08^{\prime} 20.8^{\prime \prime} \mathrm{N} & 117^{\circ} 10^{\prime} 57.4^{\prime \prime} \mathrm{W} & 102.0 & 1165 & 0.2533 & 0.70561 & 52 & 0.7054 \\ 837-10 \mathrm{~B} & 48^{\circ} 05^{\prime} 52.3^{\prime \prime} \mathrm{N} & 117^{\circ} 18^{\prime} 18.0^{\prime \prime} \mathrm{W} & 94.5 & 1489 & 0.1836 & 0.70571 & 52 & 0.7056 \\ 837-10 \mathrm{C} & 48^{\circ} 05^{\prime} 52.7^{\prime \prime} \mathrm{N} & 117^{\circ} 18^{\prime} 15.1^{\prime \prime} \mathrm{W} & 98.6 & 1135 & 0.2513 & 0.70595 & 52 & 0.7058 \\ 877-28 \mathrm{~F} & 48^{\circ} 14^{\prime} 03.0^{\prime \prime} \mathrm{N} & 116^{\circ} 41^{\prime} 49.8^{\prime \prime} \mathrm{W} & 52.6 & 1345 & 0.1131 & 0.70537 & 50 & 0.7053 \\ 877-29 \mathrm{D} & 48^{\circ} 12^{\prime} 46.6^{\prime \prime} \mathrm{N} & 117^{\circ} 17^{\prime} 22.2^{\prime \prime} \mathrm{W} & 79.6 & 1697 & 0.1357 & 0.70578 & 52 & 0.7057\end{array}$




\section{FIGURE CAPTIONS}

Figure 1. Location of the Coeur d'Alene mining district in northern Idaho and distribution of major mines. Symbols show approximate locations of mines referred to in the text: $B$, Bullion; BH, Bunker Hill; C, Coeur; CA, Caladay; CH, Carbonate Hill; G, Galena; GH, Gold Hunter; HS, Highland Surprise; LF, Lucky Friday; M, Matchless; S, Sunshine; SC, Success; SM, Star-Morning; SS, Silver Summit. Sampled ore-bodies are identified in Table 1.

Figure 2. Rb-Sr correlation diagram of carbonate minerals of the Coeur d'Alene mining district.

Note that a 1600-Ma reference isochron appears near the $\mathrm{X}$ axis and that all analyses of vein carbonates lie above it in a generally random distribution.

Figure 3. $\mathrm{Rb}-\mathrm{Sr}$ correlation diagram of mean ${ }^{87} \mathrm{Sr} /{ }^{86} \mathrm{Sr}$ and $1 / \mathrm{Sr}$ values of carbonate minerals from individual vein systems of the Coeur d'Alene mining district. The inverse correlation of ${ }^{87} \mathrm{Sr} /{ }^{86} \mathrm{Sr}$ with $\mathrm{Sr}$ in the veins probably reflects a mixing of low-Sr, high${ }^{87} \mathrm{Sr} /{ }^{86} \mathrm{Sr}$ fluids derived from old, high- $\mathrm{Rb} / \mathrm{Sr}$ sources with those leached from high-Sr, marine carbonate rocks.

Figure 4. Correlation diagram of mean $\delta^{13} \mathrm{C}$ and $\delta^{18} \mathrm{O}$ results for carbonate minerals from individual vein systems of the Coeur d'Alene mining district, Idaho. Positive correlation of $\delta^{13} \mathrm{C}$ and $\delta^{18} \mathrm{O}$ is typical of the covariation of these isotopic systems in other carbonate-gangue ore deposits.

Figure 5. Stable-isotope, $1 / \mathrm{Sr}$, and ${ }^{87} \mathrm{Sr} / 86 \mathrm{Sr}$ results for siderite from a sample traverse $(10 \mathrm{~cm}$ spacing) of the Copper vein in the Sunshine Mine documents the covariation of $\delta^{18} \mathrm{O}$ and $\delta^{13} \mathrm{C}$. The smooth decrease in both stable isotopes from wall to center suggests an inward progressing crystallization of the vein during steadily increasing fluid temperature (Eaton et al., 1995). Variations in Sr show no apparent correlation with stable isotope variations, but exhibit a strong correlation of $1 / \mathrm{Sr}$ and ${ }^{87} \mathrm{Sr} /{ }^{86} \mathrm{Sr}$. This inverse correlation between $\mathrm{Sr}$ and ${ }^{87} \mathrm{Sr} /{ }^{86} \mathrm{Sr}$ indicates a mixing relationship between 
components with high $\mathrm{Sr}$, low ${ }^{87} \mathrm{Sr} /{ }^{86} \mathrm{Sr}$ (such as Belt limestone or dolomite) and low $\mathrm{Sr}$, high ${ }^{87} \mathrm{Sr} /{ }^{86} \mathrm{Sr}$ (such as radiometrically evolved Belt argillite). Both correlated variations are consistent with primary crystallization from vein fluids and inconsistent with post-depositional metamorphic homogenization.

Figure 6. Stable-isotope and ${ }^{87} \mathrm{Sr} /{ }^{86} \mathrm{Sr}$ sample traverses $(10 \mathrm{~cm}$ spacing $)$ of the $\mathrm{D}$-vein in the Sunshine Mine show patterns of vein deposition with very large, irregular fluctuations in siderite isotopic composition. Co-variation in $\delta^{18} \mathrm{O}$ and ${ }^{87} \mathrm{Sr} / 86 \mathrm{Sr}$ document a clear but inexact anti-correlation of the two chemically and isotopically unrelated species. The same inverse relationship is even apparent in the faulted portion of the vein. Because a pressure/temperature control of $\mathrm{Sr}$ isotope variation is highly improbable, the well-established pattern of stable-isotope fractionation may have been superimposed on source-related isotopic variations in the fluids during the course of vein formation. Regardless of the control of fluid composition, however, the isotopic variations appear to be primary fluid phenomena, with the same interrelationship throughout the period this vein was being deposited. Note that $\delta^{18} \mathrm{O}$ values in the adjacent Revett Formation host rocks are below those of the vein, but that host-rock values increase toward the vein. Isotopic disequilibrium is found not only between the vein and host, but also between vein minerals, precluding a post-depositional metasomatic metamorphism that would homogenize isotopic ratios. Faulting in the vein documents post-emplacement deformation, repeating a part of the vein..

Figure 7. Comparison of measured ${ }^{87} \mathrm{Rb} /{ }^{86} \mathrm{Sr}$ and ${ }^{87} \mathrm{Sr} /{ }^{86} \mathrm{Sr}$ in rocks of the Belt Supergroup and separated carbonate minerals from veins of the Coeur d'Alene mining district. Note that the extreme ${ }^{87} \mathrm{Sr} /{ }^{86} \mathrm{Sr}$ values established in the vein carbonates during ore deposition is only matched by the highest ${ }^{87} \mathrm{Sr} /{ }^{86} \mathrm{Sr}$ values of present-day Belt strata.

Figure 8. Comparison of ${ }^{87} \mathrm{Rb} /{ }^{86} \mathrm{Sr}$ and ${ }^{87} \mathrm{Sr} /{ }^{86} \mathrm{Sr}$ values calculated for rocks of the Belt Supergroup and Coeur d'Alene carbonate vein minerals as they would have been 850 m.y. ago. Because the ${ }^{87} \mathrm{Sr} /{ }^{86} \mathrm{Sr}$ of the carbonates is virtually unchanged in $850 \mathrm{~m} . \mathrm{y}$. 
due to their minimal Rb contents, whereas the high- $\mathrm{Rb} / \mathrm{Sr}$ Belt strata have increased as shown, Belt rocks could not have been the source of the highly radiogenic vein $\mathrm{Sr}$ at $850 \mathrm{Ma}$ or earlier. As discussed in the text, no other sources in northern Idaho would have had sufficiently elevated ${ }^{87} \mathrm{Sr} /{ }^{86} \mathrm{Sr}$ to produce the values observed in the veins. Consequently, the veins must have formed much more recently, probably in Cretaceous time.

Figure $9 .{ }^{87} \mathrm{Rb} / 86 \mathrm{Sr}$ and ${ }^{87} \mathrm{Sr} /{ }^{86} \mathrm{Sr}$ values calculated at $850 \mathrm{~m}$.y. ago for Archean rocks from western Montana and eastern Washington compared to the same parameters calculated for carbonate vein minerals of the Coeur d'Alene mining district. Although $\mathrm{Rb}-\mathrm{Sr}$ whole-rock isochron ages calculated for the Archean rocks (James and Hedge, 1980; Henry et al., 1982; Wooden and Mueller, 1988; Mock et al., 1988; Mueller et al., 1993) yield values ranging from $3400 \mathrm{Ma}$ to $2600 \mathrm{Ma}, \mathrm{Rb} / \mathrm{Sr}$ ratios of these rocks are much less than rocks of the Belt Supergroup, which by $850 \mathrm{Ma}$ had reached similar ${ }^{87} \mathrm{Sr} /{ }^{86} \mathrm{Sr}$ values. Note that neither group has sufficiently radiogenic ${ }^{87} \mathrm{Sr} /{ }^{86} \mathrm{Sr}$ at $850 \mathrm{Ma}$ to provide the values as high as 1.6 measured in the ore-bearing veins. Increasing the age of mineralization to $1000 \mathrm{Ma}$, as proposed by Rosenberg and Larson (1996) and Leach et al. (1998), would result in even lower ${ }^{87} \mathrm{Sr} /{ }^{86} \mathrm{Sr}$ in either the Archean or Belt rocks and make them even less appropriate as sources of the radiogenic Sr. As shown, only in late Phanerozoic time have ${ }^{87} \mathrm{Sr} /{ }^{86} \mathrm{Sr}$ ratios in the Belt strata reached appropriate levels. 


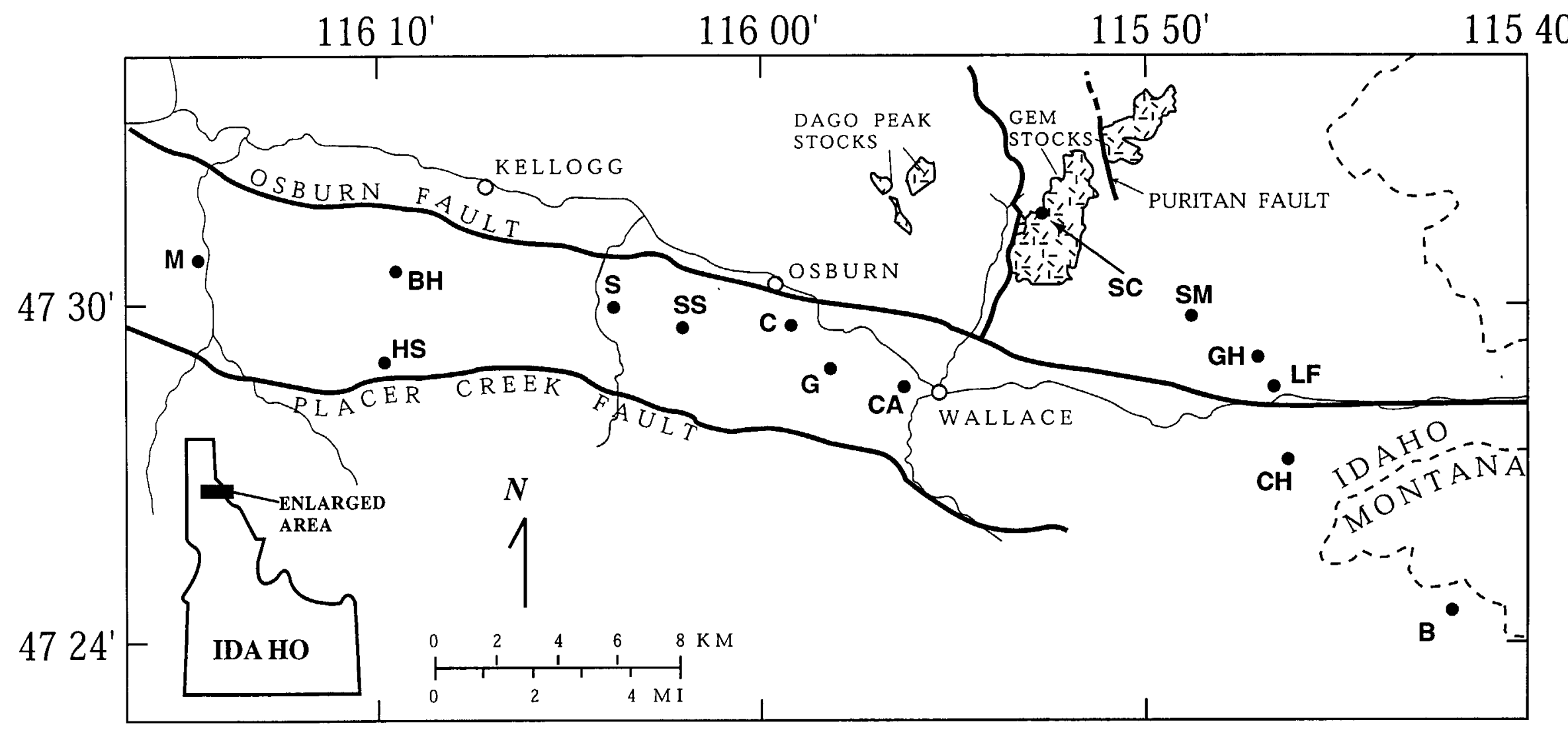




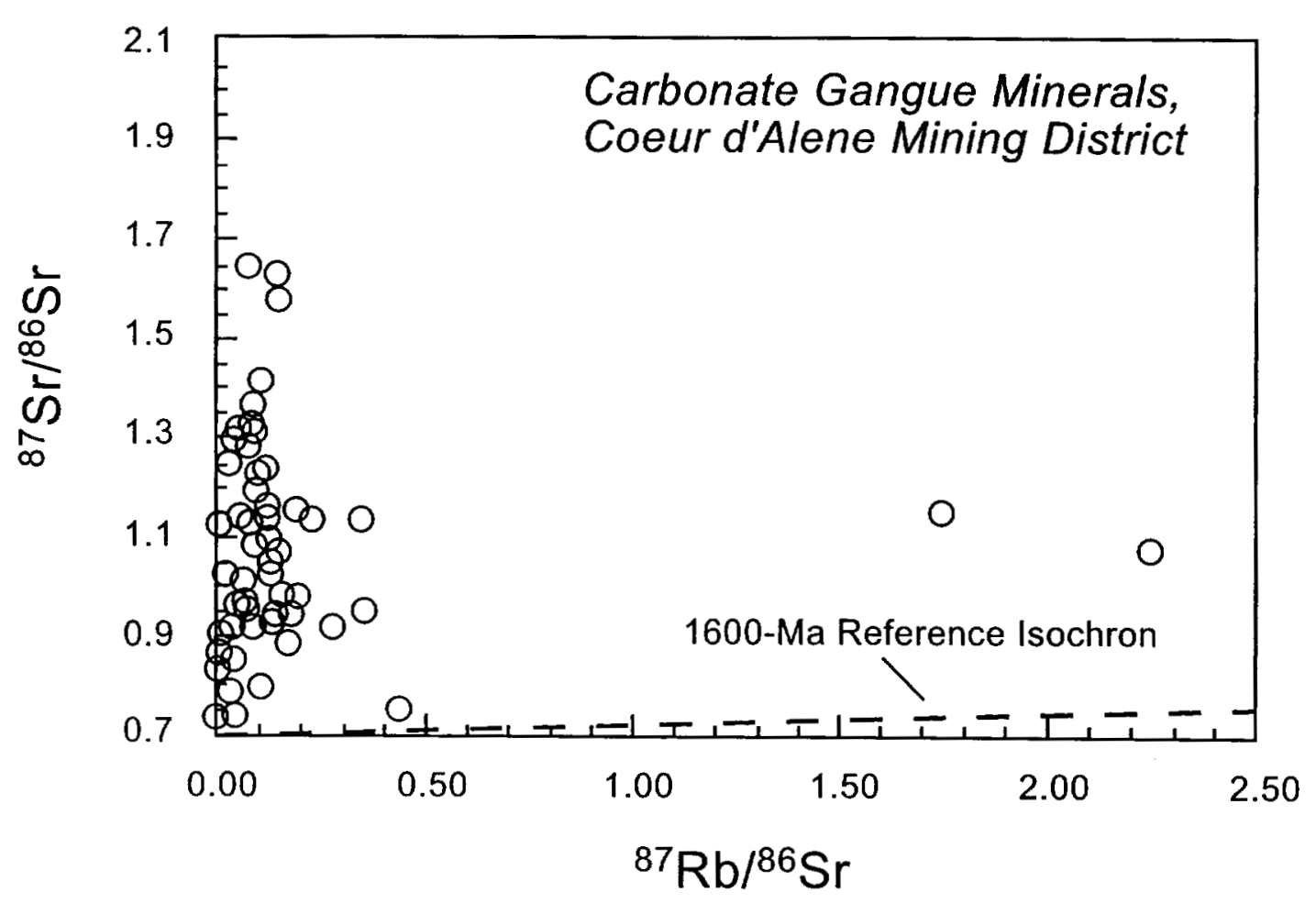

Figure 2 


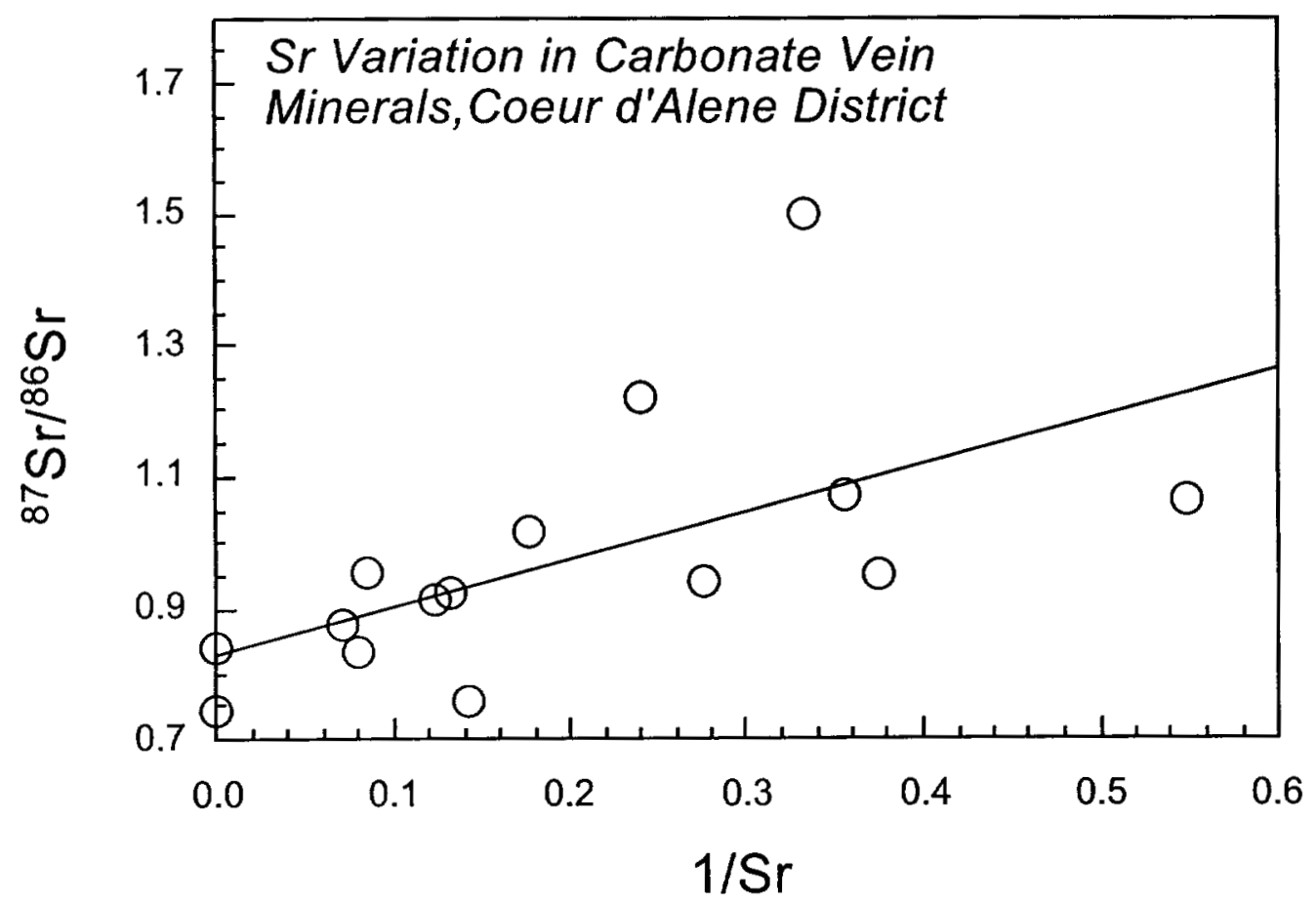

Figure 3 


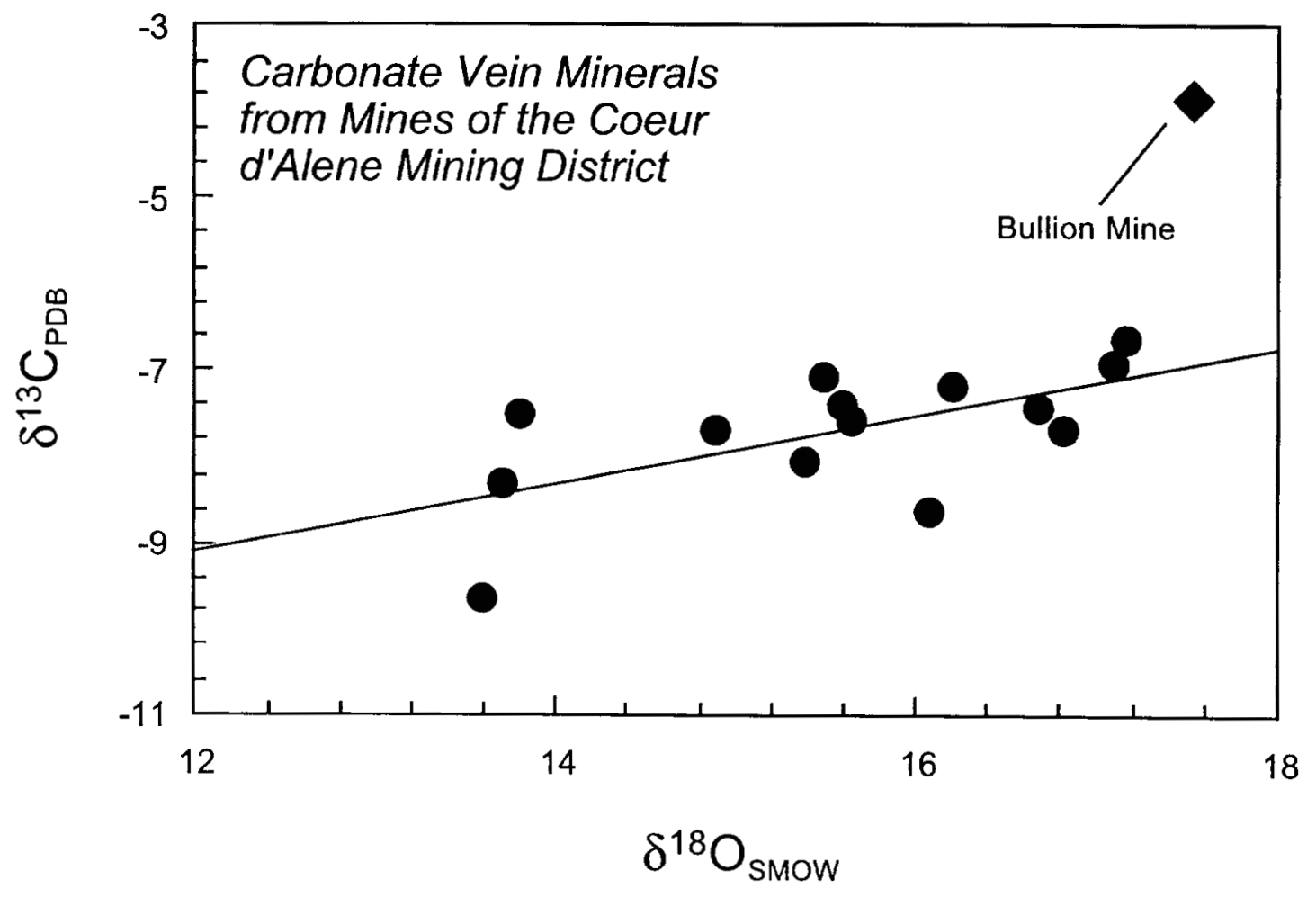

Figure 4 


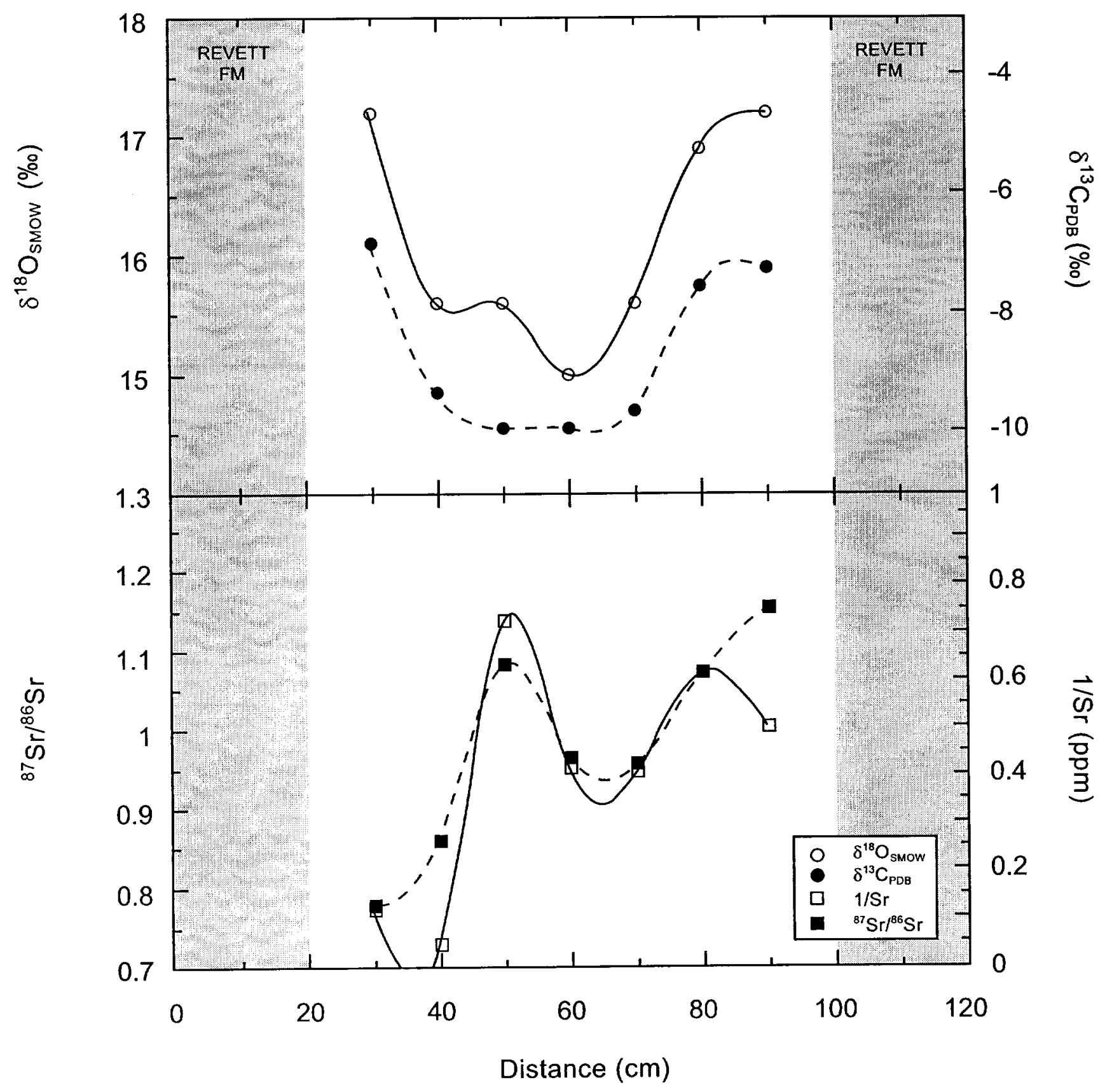

Figure 5 


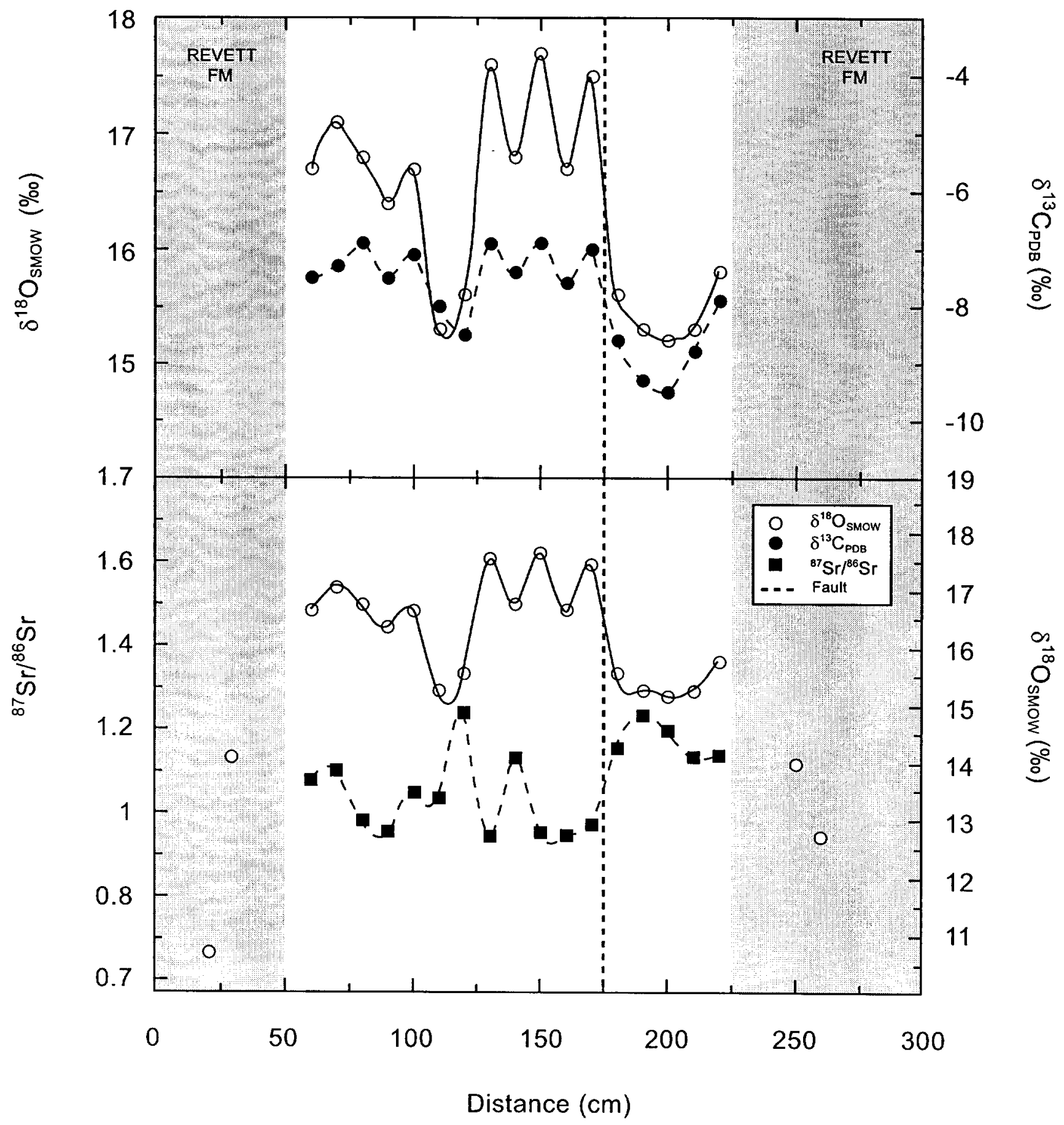

Figure 6 


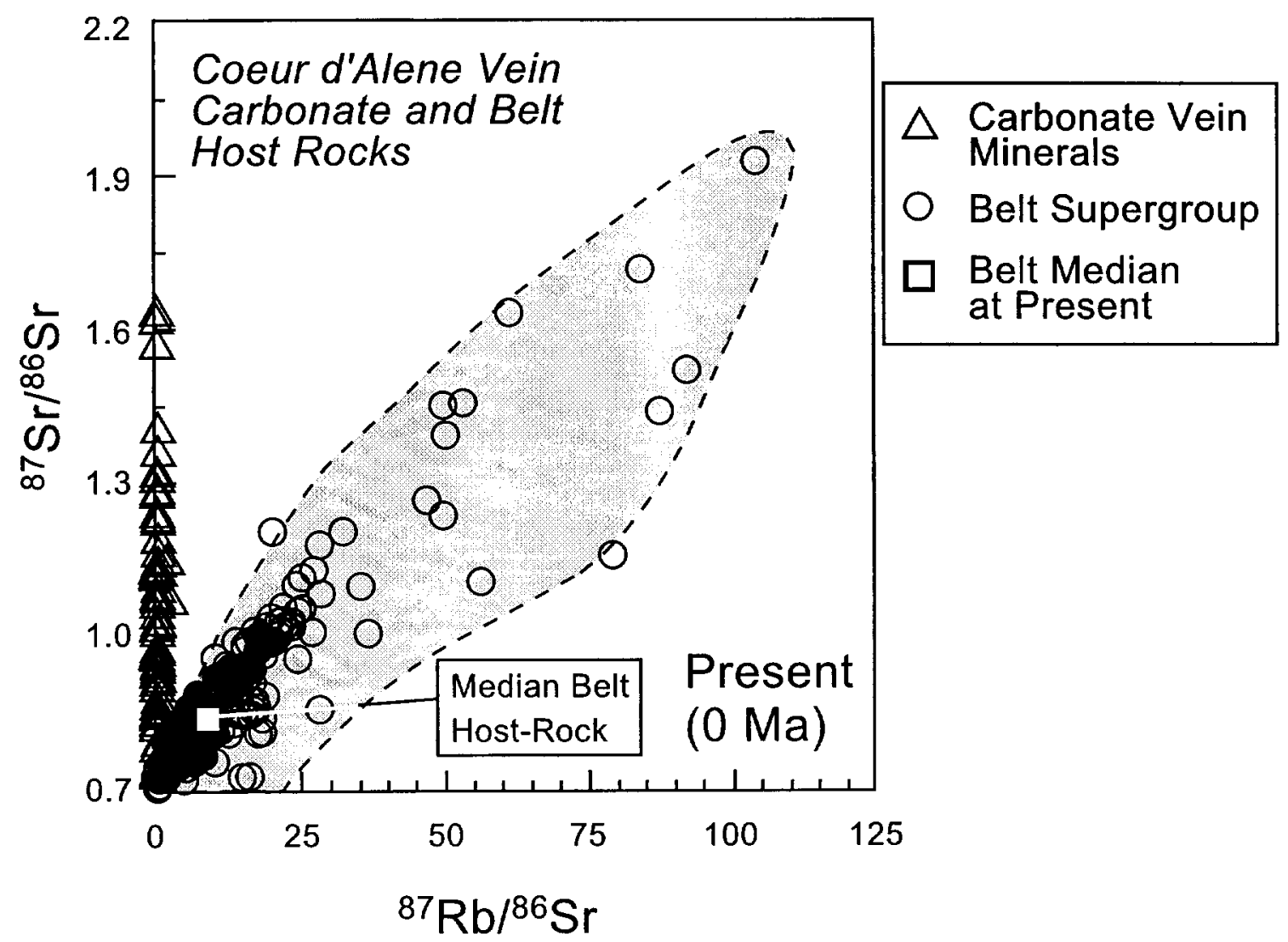

Figure 7 


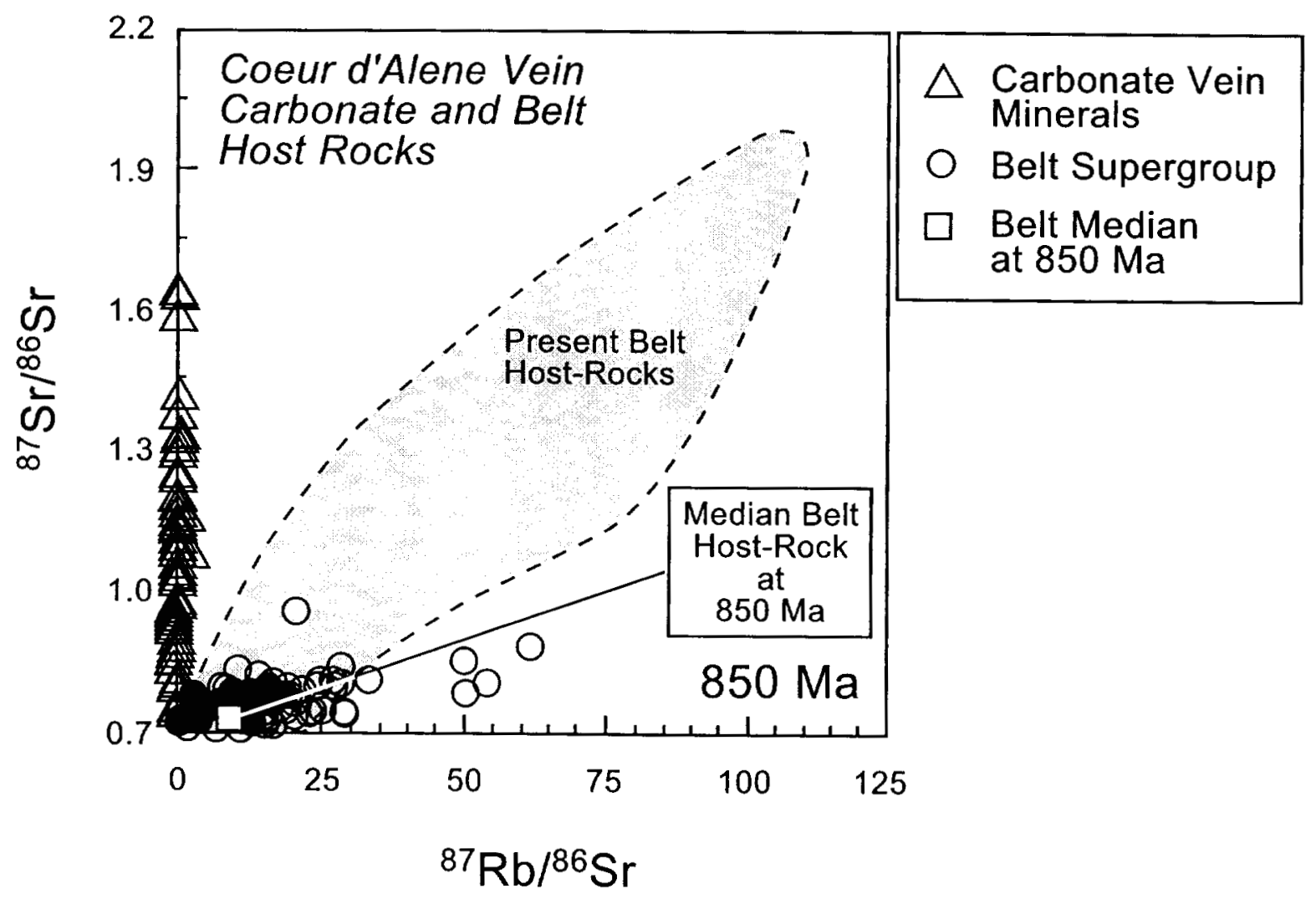

Figure 8 


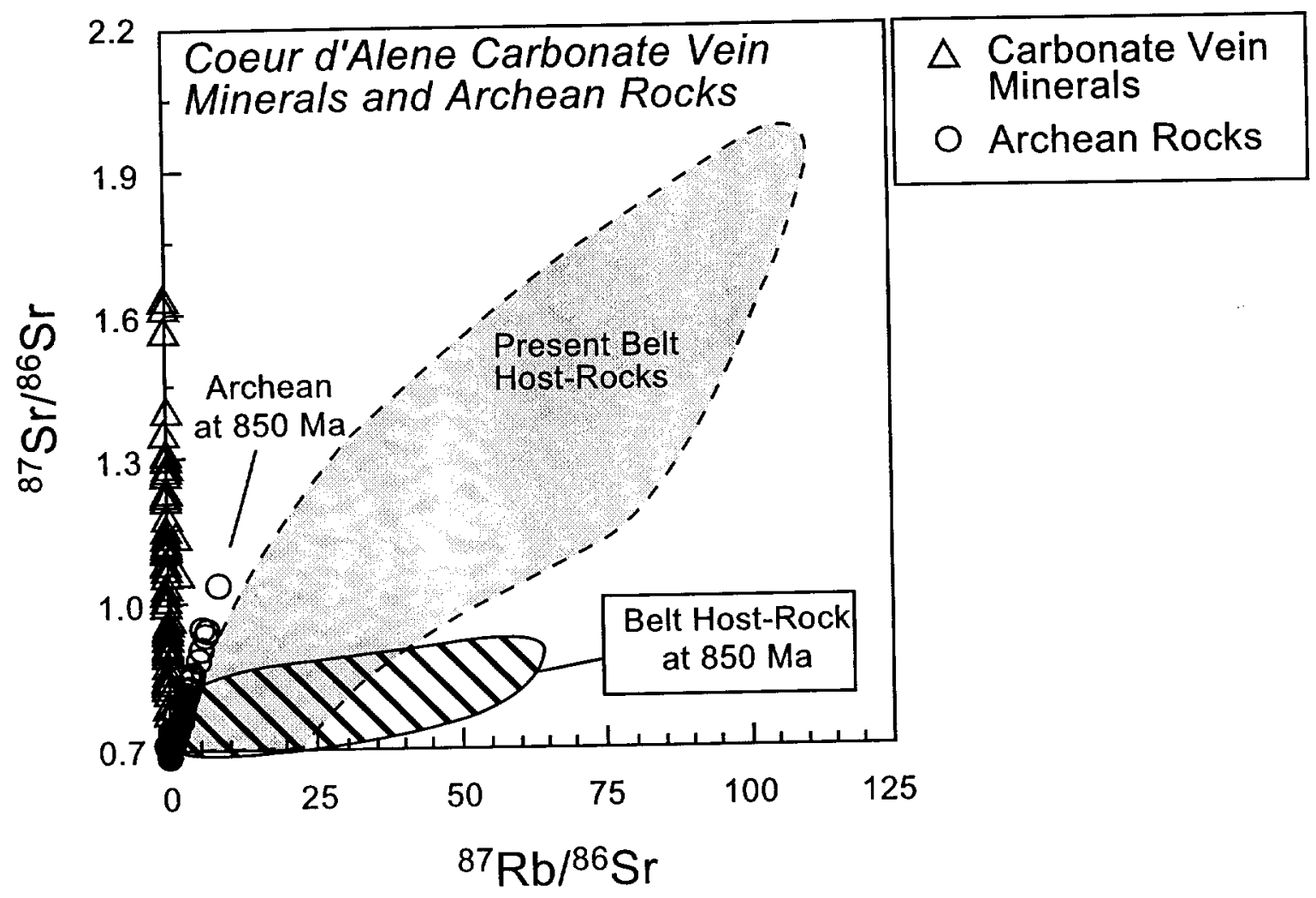

Figure 9 